\author{
UNIVERSIDADE DE SÃO PAULO \\ FACULDADE DE FILOSOFIA, LETRAS E CIÊNCIAS HUMANAS \\ DEPARTAMENTO DE LINGUÍSTICA \\ PROGRAMA DE PÓS-GRADUAÇÃO EM LINGUÍSTICA
}

\author{
JULIO WILLIAM CURVELO BARBOSA
}

\title{
Variação paramétrica em predicados complexos e nomes compostos: um estudo translinguístico
}

Tese apresentada ao programa de Pós-Graduação em Linguística da Faculdade de Filosofia, Letras e Ciências Humanas da Universidade de São Paulo, como requisito parcial para a obtenção do título de Doutor em Linguística.

Área de Concentração: Linguística

Orientador: Profa. Dra. Esmeralda Vailati Negrão

\section{VERSÃO CORRIGIDA}

De acordo,

Profa. Dra. Esmeralda Vailati Negrão 


\section{Variação paramétrica em predicados}

\section{complexos e nomes compostos: um}

\section{estudo translinguístico}

Tese apresentada ao programa de Pós-Graduação em Linguística da Faculdade de Filosofia, Letras e Ciências Humanas da Universidade de São Paulo, como requisito parcial para a obtenção do título de Doutor em Linguística.

Área de Concentração: Linguística

Orientador: Profa. Dra. Esmeralda Vailati Negrão

BANCA EXAMINADORA

Profa. Dra. Esmeralda Vailati Negrão

Instituição: FFLCH - USP

Presidente

Prof. Dr. Alessandro Boechat de Medeiros

Instituição: UFRJ - Externo

Titular

Profa. Dra. Tereza Cristina Wachowicz

Instituição: UFPR - Externo

Titular

Profa. Dra. Ana Paula Scher

Instituição: FFLCH - USP

Titular

Profa. Dra. Evani de Carvalho Viotti

Instituição: FFLCH - USP

Titular 
À Dona Rosa: doutora na vida, meu maior orgulho e motivação. 


\section{Agradecimentos}

Primeiramente, agradeço à minha orientadora, Profa. Drª. Esmeralda Vailati Negrão, com quem tive a honra de conviver ao longo de oito anos como pesquisador. Sua postura gentil, séria e dedicada sempre foi grande inspiração para me tornar um pesquisador que gosta do que faz, me ajudando a superar meus medos, e a produzir apesar dos obstáculos que a vida teima em, às vezes, nos impor. Se hoje sou linguista, é a você que devo a maior parte dessa conquista. Muitas pessoas possuem a oportunidade de aprender com você. Poucos felizardos, porém, são contemplados com a chance de ser um de seus "filhos". Obrigado por tudo.

Agradeço à Profa. Dra. Ana Paula Scher, a grande "culpada" por eu ter entrado na vida acadêmica, e por sempre me motivar a continuar nela. Obrigado pela amizade, pelos bons conselhos, e por acreditar que eu me tornaria "doutor antes dos 30 ".

À Profa. Dra. Evani Viotti e à Profa. Drá. Ana Paula Scher, agradeço pelos comentários no exame de qualificação, e pela presença na banca de defesa. Desde o mestrado, aprendi muito com os seus pontos de vista, apesar de sempre teimar em inventar maluquices e misturar teorias, apesar de ser sempre avisado dos riscos. Aos Profs. Alessandro Boechat de Medeiros e Teresa Cristina Wachowicz, agradeço pela participação na banca de defesa. Apesar da ansiedade da véspera, me sinto seguro em saber que estou cercado de pessoas extremamente competentes que podem discordar das minhas ideias, mas me farão sempre pensar de maneira crítica sobre os fatos que proponho discutir.

Agradeço aos professores do Departamento de Linguística, os quais admiro muito, e que nunca vi se negaram a ajudar um aluno (seja orientando, ou não) em um momento de necessidade. Ao Marcos Lopes, um obrigado especial pelos treinos de boxe, pelas aventuras gastronômicas, e pela habilidade conquistada no Guitar Hero. 
Agradeço também aos funcionários do DL, Ben Hur, Robson e Érica, por facilitarem a vida de todos nós, por serem sempre simpáticos e prestativos, e por sempre ajudarem a manter um ambiente leve, mesmo quando a gente chega de casa com a cabeça cheia de complicações.

Agradeço aos professores Veneeta Dayal, Ken Safir, Jane Grimshaw e Mark Baker, juntamente aos outros professores do Departamento de Linguística da Rutgers University, o os quais tive a oportunidade de conviver durante o ano acadêmico de 2010-2011. Obrigado Pete \& Sara O'Neill, Ryan \& Amanda Denzer-King, Patrick \& Paula Houghton, Will \& Alisson Bennet, Matt Barros, Jeremy Perkins, Jimmy Bruno e Aaron Braver. Thanks for taking me in!

Um obrigado especial ao Marcus Avelar, que me acolheu em NY nos meses em que estive homeless, pelas conversas e pela companhia na big apple, e ao Rerisson Cavalcante, pelas pizzas debaixo de neve, pelos passeios em DC, Philly, NY e New Jersey. Amigos bons são amigos até de longe!

Agradeço - provavelmente sem conseguir fazer justiça a todos - aos colegas de profissão, sejam da graduação, sejam da pós. A boa convivência com o grupo desse departamento me fez sentir em casa, e ajudou a passar por esses anos como se fossem meses. Vou sentir saudades das risadas no bandejão, de tomar um café, ou fazer qualquer coisa fora da USP, apesar de discutirmos sobre nossos trabalhos quase que o tempo todo: Leonor Simioni, Rafael Minussi, Paula Armelin (estes últimos "três mosqueteiros/co-autores"), Rerisson Cavalcante, Lidia Silva, Marcus Lunguinho, Mariana Resenes, Lara Frutos, Luciana Sanchez-Mendes, Vitor Nóbrega, João Paulo Cyrino, Janayna Carvalho. Da mesma maneira, agradeço aos amigos que não estão mais na USP, mas estão sempre presentes quando possível: Renato Lacerda, Rita Demasi, Thiago Coutinho-Silva, Lucia Silva e Marcus Avelar.

Agradeço também aos integrantes do GREMD, do qual sou "membro fundador", desde 2004. Obrigado pelas discussões e por compartilharem o que sabem, com humildade e alegria. 
Agradeço ao Rafael Minussi, meu irmão acadêmico, e um irmão na vida também. Valeu pelo apoio nas crises, nos trabalhos acadêmicos e viagens em parceria, pelas críticas e pelo ponto de vista que me fez me sentir desafiado - no melhor sentido da palavra - a me superar e explicar melhor os meus pontos de vista. הלך תוד

Um obrigado especial à Aline Garcia Rodero Takahira, cuja ajuda foi essencial para formatar as referências (bibliográficas ou não!).

Aos meus pais, que não deixaram de me motivar e de acreditar em mim.

Agradeço também ao CNPq, que contribuiu para o financiamento deste trabalho, seja na bolsa regular, seja no estágio em Rutgers.

Depois de 8 anos de pesquisa, e mais de 10 na USP, é muito difícil lembrar de todas as pessoas que mereceriam agradecimentos. Depois de fazer os agradecimentos da Dissertação, sempre parece que eu estou "copiando": de fato, eu estou - dadas as devidas modificações. Muitas pessoas importantes passaram e me deixaram contribuições intelectuais, emocionais e até espirituais para que essa tese ficasse pronta. Aos que não tiverem seus nomes registrados, mas se sentirem em débito, saibam que minha memória pode não ser das melhores, mas minha gratidão permanece em boas energias endereçadas à vocês. 
"So check it out, right: I've tried every approach to living. I've tried it all. I haven't tried everything, but I've tried every approach. Sometimes you have to try everything to get the approach the same, but... I've tried it all. I've bought a bunch of stuff. I went "nehh, I don't like that." I kinda came in and out of that a couple of times.

I thought I would shut myself off. I thought maybe that's cool. Maybe that's what you have to do to be a genius is you have to be mad. So, if you can get mad before the word genius, then maybe you can make genius appear. Right? That doesn't work either.

And I'm in a good place. I've paced myself pretty well. I'm [almost] 30, I've seen some cool stuff. I made a lot of stuff happen for myself. I made a lot of stuff happen for myself, right? That's a really cool sentence when you're in your 20s, "I made it happen for myself", right? But all that means is that I've just somehow or another found a way to synthesize love. Or synthesize soothing. You can't get that, and what I'm saying is I've messed with all the approaches except for one, and it's gonna sound really corny, but that's just love. That's just love.

I've done everything in my life that I've wanted to do except just give and feel love for my living. And I don't mean like, uh, Roman candle, firework, Hollywood hot pink love. I mean, like, "I got your back"-love. I don't need to hear "I love ya." You guys love me, I love you. We got that down. But some of the people who would tell you that they love you are the same people who will, at last, just have your back. So I'm gonna experiment with this love thing. Giving love. Feeling love. I know it sounds really corny, but it's the last thing I've got to check out before I check out. 


\section{$\underline{\text { Resumo }}$}

O objetivo desta tese é discutir a noção de Parâmetro dentro da Gramática Gerativa (CHOMSKY, 1986, inter alia), com base na observação de dados do português brasileiro (doravante PB) e do inglês, partindo das definições apresentadas no Parâmetro de Composição (SNYDER, 1995, 2001).

A partir da descrição das propriedades formais dos dados das duas línguas acima mencionadas, esta tese mostra que o Parâmetro de Composição - da maneira como é definido - precisa ser reformulado, seja do ponto de vista do seu escopo empírico, seja da sua definição formal, pelos seguintes fatos: (a) os nomes compostos $\mathrm{N}+\mathrm{N}$ do inglês se mostram semanticamente idênticos a expressões nominais complexas do tipo $\mathrm{N}+d e+\mathrm{N}$ do $\mathrm{PB}$, e o Parâmetro de Composição depende exatamente da presença de compostos $\mathrm{N}+\mathrm{N}$ para explicar sua distinção paramétrica; (b) a definição de predicados complexos proposta por Snyder é muito abrangente, dado que o PB apresenta construções que, segundo a formulação do referido parâmetro, não deveriam ser permitidas nessa língua, como (i) construções causativas, (ii) construções locativas (iii) construções dativas e (iv) construções perceptuais. É motivado, então, propor que essas construções não devam ser consideradas parte do escopo do parâmetro proposto por Snyder (op. cit.).

Por conta da necessidade da reformulação dos fenômenos empíricos abarcados pelo Parâmetro de Composição, é apresentada uma nova análise em que há não um, mas dois parâmetros em jogo. Restritos pelo Parâmetro de Emolduração, predicados complexos puros, como construções resultativas, verbo+partícula e, consequentemente, isolamento de preposição, são impossíveis em PB por consequência das suas características tipológicas de 
emolduração - sendo essa uma língua emoldurada pelo verbo (TALMY, 2000) - analisada nesta tese como apresentando uma configuração estrutural semelhante a uma estrutura diádica composta (HALE; KEYSER, 2002). Já nomes compostos e construções de alternância dativa (construções dativas e construções de objeto duplo) são compatíveis com propriedades de estruturas diádicas básicas (idem). O segundo parâmetro - o Parâmetro de Realização Fonológica de Núcleos - é o responsável por explicar a diferença, em PF, na ordem dos elementos que participam dessas construções, apesar de leituras semânticas idênticas quando comparando inglês e PB. O suporte teórico do quadro teórico da Morfologia Distribuída (HALLE; MARANTZ, 1993) é utilizado nesta tese, pois ele permite enquadrar expressões nominais e expressões verbais sob o mesmo modelo de análise sintática. Além disso, a proposta de Mateu \& Rigau (1999) para acomodar a teoria sobre as propriedades tipológicas das línguas naturais feita por Talmy (2000) permite que as intuições e análises deste último autor pudessem ser incorporadas nesta tese, para explicar a distinção entre PB e inglês em termos puramente sintáticos, i.e., em propriedades dos traços formais e categorias funcionais envolvidas.

Como consequência do modelo em que a análise é desenvolvida, esta tese sugere que as noções de variação paramétrica devam ser revistas, já que o locus da variação (léxico versus sintaxe), assim como suas propriedades distintivas deixam de ser motivadas dentro de um sistema computacional que deriva tanto expressões nominais quanto verbais. 


\section{Abstract}

The goal of this dissertation is to discuss the notion of Parameter within Generative Grammar (CHOMSKY, 1986, among others), based on the observation of data from Brazilian Portuguese (henceforth BP) and English, departing from the definitions presented by the Compounding Parameter (SNYDER, 1995, 2001).

Based on a description of the formal properties of the data in both of the above mentioned languages, this dissertation shows that the Compounding Parameter - in the way it is defined - needs a reanalysis, both from the point of view of its empirical scope and its formal definition, for the following facts: (a) English $\mathrm{N}+\mathrm{N}$ compounds are shown to be semantically identical to complex nominal expressions of the type $\mathrm{N}+d e+\mathrm{N}$, from $\mathrm{BP}$, and the Compounding Parameter depends exactly on the presence of $\mathrm{N}+\mathrm{N}$ compounds in order to explain its parametric distinction; (b) the definition of complex predicates proposed by Snyder is too broad, given that BP presents constructions that, given the formulation of the mentioned parameter, should not be allowed in this language, such as (i) causative constructions, (ii) locative constructions, (iii) dative constructions and (iv) perceptual constructions. It is motivated, then, to claim that these constructions should not be considered part of the scope of the parameter proposed by Snyder (op. cit.).

Provided the need to reformulate the empirical relations the Compounding Parameter suggests, a new analysis is presented, in which there is not one, but two parameters at stake. Restricted by the Framing Parameter, pure complex predicates, such as resultative constructions, verb-particle and, consequently, preposition stranding, are not possible in BP 
due to its verb-framed typological characteristics (TALMY, 2000) - presenting a structural configuration similar to a composite dyadic structure (HALE; KEYSER, 2002). Compounds and dative shift constructions (dative constructions and double object constructions), on the other hand, are compatible with basic dyadic structures (idem). The second parameter - the Phonological Head Realization Parameter - is the responsible for explaining the difference, at $\mathrm{PF}$, in the order of the elements which play a role in these constructions, despite identical semantic readings when comparing English and BP. The theoretical support from the Distributed Morphology framework (HALLE; MARANTZ, 1993) is used on this dissertation, since it allows placement of both nominal and verbal expressions under the same syntactic analysis model. Besides this fact, Mateu \& Rigau's (1999) proposal to accommodate the theory about the typological properties of the natural languages, made by Talmy (2000) allows that the intuitions and analyses of this last author could be incorporated into this dissertation, in order to explain the distinction between BP and English on purely syntactic terms, i.e., by the properties of the forma features and functional categories involved. As a consequence of the model in which the analysis is developed, this dissertation suggests that the notions of parametric variation should be revised, since the locus of variation (lexicon versus syntax), as well as its distinctive properties are no longer motivated within a computational system that derives both nominal and verbal expressions. 


\section{Sumário}

1. As noções de parâmetro e predicado complexo: considerações iniciais...................... 14

1.1. A noção de parâmetro na Gramática Gerativa.................................................. 14

1.1.1. O Parâmetro de Composição (SNYDER, 1995, 2001)..................................... 18

1.1.2. Microparâmetros versus macroparâmetros................................................... 21

1.2. Aproximando a noção de Parâmetro à Semântica Cognitiva................................. 26

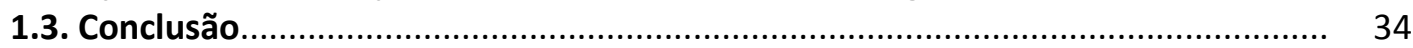

2. Redefinindo e reclassificando o Parâmetro de Composição.......................................... 36

2.1. Observando o Parâmetro de Composição translinguisticamente......................... 37

2.1.1. Questões empíricas: o ponto de vista do PB.................................................. 37

2.1.1.1. Aquisição de predicados complexos no PB: um estudo-piloto.................... 50

2.1.2. Observando a perspectiva de evento: fatores de classificação de

predicados complexos

2.1.2.1. Talmy (2000): Emolduração e a estrutura de (macro)eventos.................... 53

2.1.2.2. Questões translinguísticas acerca dos macroeventos e a classificação dos predicados complexos relevantes ao Parâmetro de Composição........ 58

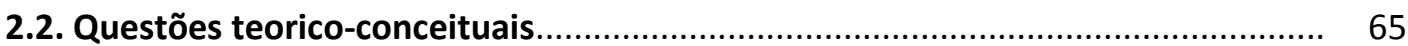

2.2.1. O que são predicados complexos?..................................................................... 66

2.2.2. Morfologia Distribuída: um breve panorama ..................................................... 72

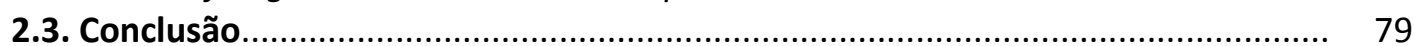

3. O Parâmetro de Realização Fonológica de Núcleos: reanalisando a estrutura de

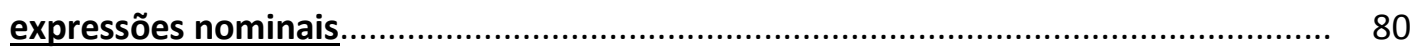

3.1. Processos de formação de palavras..................................................................... 82

3.1.1. Bases, raízes, afixos, derivação e composição: a formação de palavras no inglês..

3.1.2. A formação de palavras no PB: contrastes entre derivação e composição........ 84

3.1.3. Kehdi (1992): Propriedades sintáticas dos compostos do PB........................... 86

3.1.4. Propriedades gerais dos nomes compostos no inglês...................................... 90

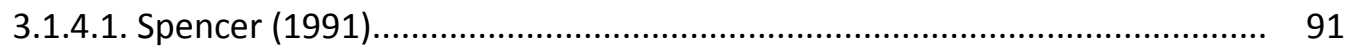

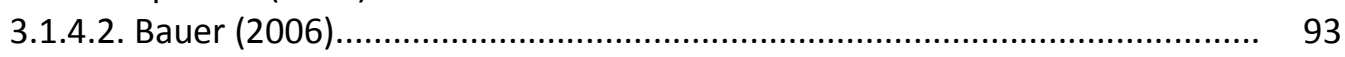

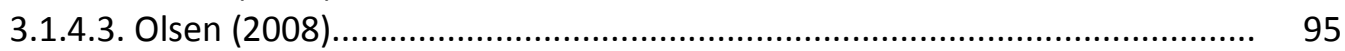

3.2. Propriedades das expressões nominais complexas do PB: uma comparação

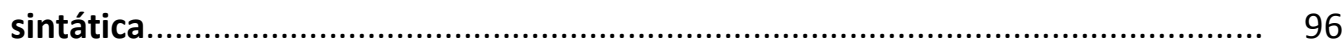

3.2.1. Uma aproximação entre os compostos do PB e do inglês................................. 96

3.2.2. Marantz (2001) e a questão da idiomaticidade: explicando a interpretação composicional...................................................................................... 107

3.3. Uma nova proposta de análise para os compostos a partir dos dados do PB...... 110

3.3.1. Di Sciullo (2005) e a projeção F................................................................... 110

3.3.2. A projeção F na Morfologia Distribuída: analisando os compostos do inglês

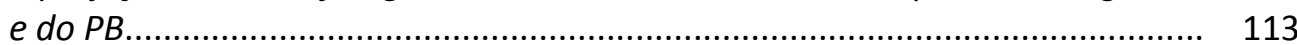

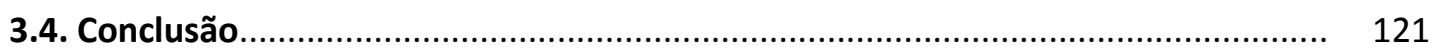

4. Derivando a alternância dativa a partir do Parâmetro de Realização Fonológica de

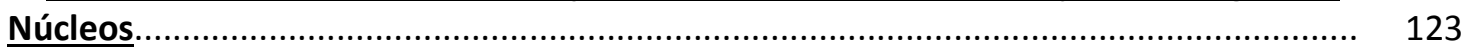

4.1. A alternância dativa: uma breve descrição......................................................... 125

4.1.1. VP shell: a análise de Larson (1988)......................................................... 127

4.1.2. Pesetsky (1995) \& Harley (2002): interpretações diferentes, estruturas diferentes. 
4.2. Fatores que bloqueiam a alternância dativa.

4.2.1. Não existe alternância dativa no PB: Scher (1996) \& Armelin (2011)............... 143

4.3. O Parâmetro de Realização de Fonologia de Núcleos e a alternância dativa: uma proposta de decomposição de traços.

4.3.1. Preposições ambíguas e a decomposição de $F$.

4.3.2. Argumentos em favor de uma análise unificadora para a alternância dativa: Bresnan \& Nikitina (2008)

4.4. Aplicando o Parâmetro de Realização Fonológica de Núcleos à alternância dativa: resultados e consequências.

4.5. Conclusão.

5. Construções resultativas e construções verbo+partícula: consequências da aplicação do Parâmetro de Emolduração.

5.1. Retomando a discussão: o Parâmetro de Composição ainda se faz relevante?

5.2. Derivando o Parâmetro de Emolduração a partir dos predicados complexos puros.

5.2.1. Não existem construções resultativas em PB: Barbosa (2008)......................... 174

5.2.2. Idiomaticidade em resultativas, verbo+partícula e nomes compostos.............. 178

5.3. O Parâmetro de Emolduração e sua relação com [modo] nos predicados complexos puros...

5.4. V, F ou $P$ ? Estrutura argumental $e$ as questões lexicais na variação paramétrica.

5.4.1. As estruturas de núcleo preposicional: explicando a projeção $F$.

5.4.2. as estruturas de núcleo verbal: dois tipos de predicação, um tipo de v. 


\section{Capítulo 1}

\section{As noções de parâmetro e predicado}

\section{complexo: considerações iniciais}

\subsection{A noção de parâmetro na Gramática Gerativa}

No curso evolutivo da teoria da Gramática Gerativa, nenhum momento promoveu uma revolução de proporções maiores do que a Teoria de Princípios e Parâmetros (CHOMSKY, 1981, 1986). Em momentos anteriores da Gramática Gerativa, muito se sabia sobre a estruturação da língua inglesa, ou de outras línguas, mas era impossível pensar em uma articulação entre as regras que explicitassem as gramáticas de diferentes línguas, como russo ou árabe, por exemplo. O sistema complexo de regras dava à teoria um alto poder descritivo, em detrimento do seu poder explicativo. Um dos grandes problemas oriundos dessa abordagem era explicar o problema observado na aquisição da linguagem. Como uma criança seria capaz de manipular regras extremamente complexas em tão pouco tempo? 
A Teoria de Princípios e Parâmetros veio para mudar esse panorama, e sua formulação permitiu que estudos em línguas aparentemente distantes pudessem se relacionar, e, por conta dessa visão teórica, o conhecimento sobre as línguas naturais cresceu exponencialmente nos anos que seguiram essa revolução dentro do modelo teórico Chomskyano.

A premissa fundamental da teoria de Princípios e Parâmetros é que os seres humanos são dotados com um órgão mental capaz de permitir, a qualquer indivíduo dentro de nossa espécie, adquirir qualquer língua a partir da exposição a um conjunto limitado de dados. Este órgão mental é comumente chamado de Faculdade da Linguagem.

De acordo com o que essa teoria delimita, foram propostas questões fundamentais a serem respondidas por aqueles que buscam desvendar qual o "formato" desse conhecimento que a criança obtém quando construindo a gramática de uma língua em particular. Chomsky mostra que existem, essencialmente, quatro ${ }^{1}$ questões fundamentais a serem respondidas por aqueles que buscam compreender esse conhecimento:

(1) Qual é o sistema do conhecimento? O que está na mente/cérebro do falante de inglês ou espanhol ou japonês?

(2) Como esse sistema de conhecimento desponta na mente/cérebro?

(3) Como esse conhecimento é posto em uso na fala (ou sistemas secundários tais como a escrita)?

(4) Quais são os mecanismos físicos que servem como a base material para esse sistema de conhecimento e para o uso desse conhecimento?

(CHOMSKY, 1987, p.3, tradução minha)

\footnotetext{
${ }^{1}$ É importante notar que a quarta questão está fora do escopo de "habilidade" do linguista. De fato, Chomsky (1987, p.6) diz que “... Enquanto o linguista pode prover respostas para as questões (1), (2), e (3), os cientistas do cérebro podem começar a explicar os mecanismos físicos que exibem as propriedades reveladas na teoria abstrata do linguista" (tradução minha).
} 
Para ser possível resolver esse quebra-cabeça, há outra questão crucial que deve ser levada em consideração - referida comumente por Problema de Platão - que é o fato de que uma criança é capaz de aprender uma língua em um período curto de tempo, e a partir de um conjunto de dados extremamente limitado. Graças a essa questão, a concepção de Gramática de Chomsky passa a se interessar em encontrar se existe um conjunto de axiomas responsável por determinar como a estrutura de qualquer língua natural é dada, e quais seriam esses axiomas. A Gramática Universal, como é chamada, é um conjunto de propriedades a partir das quais uma criança desenvolve a gramática de uma língua em particular à qual ele/ela é exposto/a. Enquanto princípios são conjuntos de propriedades comuns a todas as línguas, propriedades mais particulares - parâmetros - são responsáveis pela variação sintática e restrições entre as línguas do mundo.

Com esse panorama em vista, poderia se pensar que, se alguém puder determinar quais são os parâmetros e quantos deles existem, levaria a Gramática Gerativa a avançar um grande passo em direção a respostas para as questões mencionadas acima. Portanto, a observação de um fenômeno sintático em línguas distintas se torna extremamente necessária dentro desse modelo teórico. Nesta tese, serão explicitadas as propriedades de um desses parâmetros - precisamente, o Parâmetro de Composição (SNYDER, 1995) - e, consequentemente, serão determinados os mecanismos subjacentes à Faculdade da Linguagem que dizem respeito a esse conjunto de restrições formando o Parâmetro em questão. O objetivo principal da Tese será, portanto, observar dados do português brasileiro (doravante PB) que permitem atribuir uma nova perspectiva acerca do status do Parâmetro de Composição tal como formulado. A partir de observações empíricas, em especial do inglês e do português brasileiro, esta tese irá mostrar que o escopo empírico do Parâmetro de Composição deve ser modificado, e que dois parâmetros distintos, ao invés de apenas um parâmetro, são responsáveis pela impossibilidade de ocorrência de alguns dos fenômenos relacionados nos trabalhos de Snyder $(1995,2001$, inter alia). 
Por si só, a noção de parâmetro já é uma questão problemática de se tratar sem uma delimitação das propostas e definições acerca do tema, conforme veremos nas seções a seguir. É verdade que a delimitação do objeto de estudo a ser analisado ao longo de qualquer trabalho se faz sempre necessária, mas, como será visto mais adiante, também se faz necessária uma explicitação das definições usadas acerca dos termos cruciais em discussão, já que, em muitos momentos das Ciências Humanas, é a falta de uma definição consensual acerca de um determinado conceito que acaba por gerar divergências às vezes desnecessárias, fazendo surgir debates terminológicos ao invés de debates de ideias, de fato. No intuito de evitar tais problemas, as noções de parâmetro e predicado complexo serão mais bem definidas, já que elas são o ponto de partida para as discussões apresentadas adiante.

Dessa forma, este primeiro capítulo trata da definição terminológica e dos conceitos utilizados ao longo desta Tese, como a noção de parâmetro, as relações tipológicas entre línguas românicas e germânicas (caso do PB e do inglês, respectivamente), e qual a melhor maneira de abordar os dados que dizem respeito ao Parâmetro de Composição. No capítulo 2, discute-se o Parâmetro de Composição (SNYDER, 1995), suas formulações e as limitações técnicas e empíricas, a partir das quais será proposta uma nova estratégia de observação para a noção de predicado complexo, dentre outras reformulações. No capítulo 3 é proposta uma nova definição para o que se chama de composto (ou compound) em PB, com uma análise que unifica expressões $\mathrm{N}+d e+\mathrm{N}$, e um novo Parâmetro de Composição é proposto. No capítulo 4, é proposta uma análise convergente entre os compostos e as construções de alternância dativa, derivada pelas mesmas ferramentas de computação sintático-fonológica, seguindo as premissas da Morfologia Distribuída (HALLE; MARANTZ, 1993). No capítulo 5, resultativas e construções verbo+partícula são analisadas, e uma conexão com a proposta tipológica de Talmy (2000) é feita nos mesmos moldes da proposta de Barbosa (2008), porém adaptada à Morfologia Distribuída. 


\subsubsection{O Parâmetro de Composição (SNYDER, 1995, 2001)}

Snyder (1995) traz grande contribuição acerca do debate de como a variação paramétrica é expressa dentro dos sistemas gramaticais. $\mathrm{O}$ autor acredita que, apesar do fato de que nem itens lexicais específicos, nem marcadores morfológicos sejam responsáveis por tornar evidente a informação de aquisição de que a criança necessita, mesmo assim, existiria alguma informação morfológica fortemente relacionada à possibilidade de ocorrência de determinadas construções sintáticas na gramática do inglês.

Para provar essa relação entre morfologia e sintaxe, Snyder desenvolve um argumento translinguístico. De acordo com suas predições surge a seguinte relação: se uma língua permite livremente ${ }^{2}$ a formação de nomes compostos do tipo N+N como worm can ("lata de minhoca"; lit. minhoca lata), entre outros (8), então ela também permite que sejam formados predicados complexos tais como construções resultativas (e.g., John hammered the metal flat), já que, se ambas só aparecem simultaneamente nas línguas observadas pelo autor, então essas construções seriam produto do mesmo processo computacional presente na língua (cf. (9), abaixo):

(8)
a. $\left[\mathrm{N}^{\circ}\left[\mathrm{N}^{\circ}\right.\right.$ coffee $]\left[\mathrm{N}^{\circ}\right.$ cup] $]$
b. $\left[\mathrm{N}^{\circ}\left[\mathrm{A}^{\circ}\right.\right.$ black $]\left[\mathrm{N}^{\circ}\right.$ bird $\left.]\right]$
c. $\left[\mathrm{N}^{\circ}\left[\mathrm{v}^{\circ}\right.\right.$ guard] $\left.\left[\mathrm{N}^{\circ} \mathrm{dog}\right]\right]$

(SNYDER, 1995, p. 27)

\footnotetext{
2 É importante ressaltar que Snyder (1995) aponta que o fator determinante para afirmar que uma língua possui uma determinada construção sintática é a produtividade do fenômeno em questão.
} 
Table 2.1: Resultatives and $\mathrm{N}-\mathrm{N}$ compounding across languages

\begin{tabular}{||l|l|l||}
\hline Language & Resultatives & N-N Compounding \\
\hline English & YES & YES \\
\hline Dutch & YES & YES \\
\hline German & YES & YES \\
\hline Khmer & YES & YES \\
\hline Hungarian & YES & YES \\
\hline & & \\
\hline French & NO & NO \\
\hline Spanish & NO & NO \\
\hline Russian & NO & NO \\
\hline Serbo-Croatian & NO & NO \\
\hline Japanese & NO & NO \\
\hline ASL & NO & NO \\
\hline Mandarin & NO & NO \\
\hline Modern Hebrew & NO & NO \\
\hline Palestinian Arabic & NO & NO \\
\hline
\end{tabular}

(SNYDER, 1995, p. 31)

Como evidência para essa relação, Snyder faz um estudo de aquisição que mostra que, em crianças adquirindo inglês, predicados complexos como verbo+partícula surgem em sua gramática ao mesmo tempo em que surgem compostos $\mathrm{N}+\mathrm{N}^{3}$. Diferentes versões do Parâmetro de Composição podem ser vistas em (10) e (11):

(10) Parâmetro de Composição: A gramática (não) permite livremente que itens lexicais de classe aberta, não afixais, sejam marcados [+Afixal].

(SNYDER, 1995, p. 27, tradução minha)

\footnotetext{
${ }^{3}$ Nesse caso, o autor também levou em conta a primeira produção criativa das crianças como evidência da aquisição de compostos.
} 

compostos endocêntricos ${ }^{4}$ durante a derivação sintática [ ${ }^{*}$ valor não-marcado].

(SNYDER, 2001, p. 8, tradução minha)

O trabalho de Snyder não menciona explicitamente o Português Brasileiro, mas se a proposta de Barbosa (2008) for levada em consideração, o PB não apresenta construções resultativas, o que permite considerar que essa língua deva ser marcada negativamente para o Parâmetro de Composição. No capítulo 2, essa discussão será retomada, e serão apresentadas questões acerca dos tipos de predicados complexos envolvidos no Parâmetro de Composição. No caso dos nomes compostos, porém, existe um problema. Compostos $\mathrm{N}+\mathrm{N}$, se possíveis em PB, apresentam produtividade limitada. Essa questão também será abordada mais adiante, no capítulo 3.

Antes de discutir questões específicas do Parâmetro de Composição, é importante delimitar as escolhas teórico-metodológicas a partir das quais esta tese será desenvolvida. Nas seções seguintes, o foco será voltado para a delimitação das correntes teóricas que dão sustentação a este trabalho, bem como para o esclarecimento de algumas definições que tendem a ser menos uniformes do que o desejado - como o caso da noção de predicado complexo, por exemplo.

Na próxima seção, as abordagens da teoria sobre as noções de parâmetro serão abordadas, de modo a contribuir para uma definição o mais precisa possível para as premissas sobre parâmetro a serem observadas acerca do Parâmetro de Composição ao longo da tese.

\footnotetext{
${ }^{4}$ Um composto endocêntrico, em oposição a um composto exocêntrico, apresenta um dos elementos como "núcleo", numa relação determinante/determinado. Dessa forma, orange juice é endocêntrico já que orange especifica propriedades de juice. Um exemplo de composto exocêntrico seria actor-director, em que nenhum dos elementos parece complementar o significado do outro.
} 


\subsubsection{Microparâmetros versus Macroparâmetros}

Desde o surgimento da Teoria de Princípios e Parâmetros, uma das questões mais importantes a serem respondidas pelos pesquisadores dessa área diz respeito a quais são os parâmetros que seriam responsáveis por permitir que as línguas naturais sejam diferentes entre si, apesar de compartilharem o mesmo conjunto de axiomas (princípios).

Atualmente, existe um debate sobre o que se deve considerar como variação paramétrica de fato. Baker (2008b) discute essa questão, e aponta que atualmente, dois tipos de abordagens paramétricas são possíveis: a abordagem microparamétrica (e.g., KAYNE, 2005) e a abordagem macroparamétrica (e.g., BAKER, 1996). Enquanto a abordagem microparamétrica consiste na busca de efeitos pequenos - porém, não triviais - em línguas muito próximas (dialetos), a abordagem macroparamétrica busca a comparação de línguas pertencentes a famílias linguísticas sem qualquer relação entre si.

De acordo com Baker (2008b), o primeiro parâmetro a ter sido proposto dentro do modelo de Princípios e Parâmetros foi o parâmetro Pro-drop (CHOMSKY, 1981, RIZZI, 1982). Nele, efeitos sobre a realização do elemento que ocupa a posição de sujeito da sentença eram relacionados, de modo a contribuir para a caracterização das línguas, em especial línguas românicas como o francês, o espanhol e o italiano. O autor afirma que a formulação desse parâmetro, por si só, já traz consequências para a definição de uma análise paramétrica em micro- ou macroparamétrica, pois se trata de um medioparâmetro, por conta das seguintes características: 
- Diz respeito a uma regra geral da gramática, e não a traços de itens lexicais, porém, também não diz respeito a uma variação de um princípio nuclear da gramática;

- Efeitos de tamanho médio: omissão de sujeito, inversão de sujeito e efeitos de vestígio de complementizador; todos relacionados ao sujeito, mas contribuíam para caracterização das línguas abordadas pelo parâmetro;

- Comparação média: diferenças entre línguas românicas (francês, italiano, espanhol), e não entre dialetos ou línguas de famílias distintas;

Apesar de ter sido um avanço importante dentro do Gerativismo, Pro-drop foi muito questionado por abranger um conjunto de propriedades muito extenso em um único parâmetro. Em algumas línguas, algumas dessas propriedades são observadas; porém, a falta de ocorrência de todas as propriedades características de uma língua Pro-drop nas línguas observadas fez com que esse parâmetro fosse questionado, pois, apesar de abranger um número muito grande de línguas, não o fazia de maneira uniforme. Por conta das discussões acerca de como formular um parâmetro que não tivesse uma "falha" como essa, duas maneiras de estudar a variação paramétrica despontaram desde então, além da visão clássica vista em Chomsky (1981) e Rizzi (1982): as análises micro- e macroparamétricas.

Para Baker (2008b), a diferença entre os estudos micro- e macroparamétricos se dá, essencialmente, por conta de três propriedades vistas de maneira diferente em cada abordagem: (i) o locus da variação, (ii) a extensão da variação, e (iii) a metodologia de comparação. No caso de (i), a visão microparamétrica se volta para o que Baker chama de Conjectura Chomsky-Borer (13): 
Todos os parâmetros de variação são atribuídos a diferenças de traços de itens particulares (e.g. núcleos funcionais) no léxico.

(BAKER, 2008b, p.3, tradução minha)

Na contramão das propostas microparamétricas, Baker (2008b) se apoia em outra visão de análise paramétrica:

(14) Existem alguns parâmetros contidos nas propostas de princípios gerais que dão
forma à sintaxe das línguas naturais.

(BAKER, 2008b, p.3, tradução minha)

Para Baker, parâmetros compatíveis com (13) poderiam ser chamados de parâmetros lexicais, enquanto parâmetros compatíveis com (14) seriam chamados de parâmetros gramaticais.

Para qualquer trabalho que queira abordar fenômenos que lidem com esses dois conjuntos de características diferentes, é crucial abordar a questão da extensão da variação. Nas análises microparamétricas, é dito que quanto mais diferenças entre as línguas analisadas, maior o número de microparâmetros, e que variações supostamente "macroparamétricas" seriam produto da ação de um conjunto de microparâmetros em ação; já nas análises macroparamétricas, um único parâmetro pode apontar uma diferença "drástica" na arquitetura da gramática de duas línguas. $\mathrm{O}$ grande problema, qualquer que seja o ponto de 
vista adotado, é medir o impacto de um fenômeno linguístico, e sua relevância para uma diferença entre as línguas, como apontam Baker (2008b) e Kayne (2005). Porém, Baker afirma que algumas variações no léxico nunca seriam capazes de apresentar um efeito tão grande quanto qualquer variação direta na gramática de uma língua. Este fato leva à última questão, (iii): a metodologia de comparação.

Conforme dito anteriormente, as propostas microparamétricas acreditam que 0 método mais eficaz de descobrir parâmetros é por meio da análise de línguas de relação mais próxima. Decorre dessa escolha metodológica, como aponta Baker (2008b), que a busca por microparâmetros nunca revele macroparâmetros, já que a pesquisa microparamétrica leva sempre em conta a conjectura Chomsky-Borer, e a variação de traços de categorias gramaticais no léxico, em detrimento da observação de variação entre as gramáticas das línguas observadas.

Tendo em mente essa questão em particular, a visão defendida neste trabalho será, de certa forma, híbrida; enquanto a observação dos dados relacionados ao Parâmetro de Composição apontam para uma proposta macroparamétrica, a análise a ser desenvolvida aponta determinadas projeções funcionais como responsáveis pela variação observada, característica típica de análises microparamétricas (cf. (13), acima).

É inegável que a observação feita por Baker (2008a, 2008b) é extremamente convincente: o autor aponta que existe uma grande dificuldade em reduzir a variação macroparamétrica a uma série de microparâmetros, especialmente quando se leva em conta qualquer possível interação entre eles. Baker (2008a, p.236) lembra que, quando ocorre uma variação em um parâmetro de uma determinada língua, é de se esperar que essa variação afete outros sistemas da língua em questão. Se a variação é em um parâmetro que era marcado da mesma maneira em línguas próximas (e, provavelmente, na língua de origem), apenas uma análise que leva em conta a variação macroparamétrica pode explicar a maneira 
com que essa nova marcação afeta outros sistemas. Já numa análise microparamétrica, que permite que parâmetros entre línguas próximas variem sem gerar grandes diferenças na gramática, essas mudanças só afetariam a categoria funcional que modificam. Ou seja, nos casos em que existe uma variação que destoe do padrão da família linguística à qual a língua pertence, poderia ser necessário formular mais de um parâmetro para explicar algo que, do ponto de vista macroparamétrico, poderia (em alguns casos) ser explicado por apenas um parâmetro.

Apesar da escolha sobre o ponto de vista macroparamétrico, é importante ressaltar que os dois pontos de vista não precisam ser mutuamente excludentes. É possível fazer análises de variação microparamétrica sem invalidar as descobertas feitas por análises que propõem macroparâmetros. A escolha por um ponto de vista macroparamétrico em detrimento ao viés microparamétrico nesta tese se justifica pelo fato de que a comparação a ser realizada aqui compreende duas línguas que, apesar de serem originadas a partir do tronco indo-europeu, apresentam relativa distância, no sentido em que suas propriedades são mais distantes do que dialetos do italiano, por exemplo. Assim, o PB - língua românica - e o inglês língua germânica -, serão considerados línguas com afastamento suficiente para serem analisadas por meio de uma proposta macroparamétrica. Assim, acredita-se ser impossível propor uma análise microparamétrica para o Parâmetro de Composição, já que PB e inglês são, claramente, línguas cujo comportamento varia muito mais entre elas do que a variação entre alemão e inglês, ou PB e espanhol, por exemplo. Além disso, a proposta de Snyder (1995), apesar de anterior à discussão micro- e macroparamétrica, diz respeito a um macroparâmetro, por levar em conta um grupo de línguas variado e sem qualquer relação de origem entre si, como é possível observar a tabela em (9) (acima).

Apesar de o Parâmetro de Composição apresentar características que permitam que ele seja classificado como um macroparâmetro, a análise proposta adiante, se correta, 
mostrará que algumas propriedades deste Parâmetro se enquadram dentro da conjectura Chomsky-Borer - exclusivamente relevante para análises microparamétricas - o que contribui para o debate micro- versus macroparâmetros, especialmente no que diz respeito ao locus da variação. O modelo da Morfologia Distribuída (HALLE; MARANTZ, 1993), que será utilizado para a análise dos dados, levanta também questões acerca da definição de léxico, e, por conta disso, poderá ser utilizado de modo a oferecer um novo ponto de vista para os problemas que essa divisão entre as propostas paramétricas apresenta. Essas questões serão retomadas ao longo da tese a partir do capítulo 3.

\subsection{Aproximando a noção de parâmetro à Semântica Cognitiva}

O trabalho de Talmy (2000) se insere dentro da corrente teórica da Linguística Cognitiva conhecida como Semântica Cognitiva, que, ao contrário da Gramática Gerativa, não busca universais no componente gramatical, mas na organização conceitual da linguagem pelo ser humano.

Talmy afirma que a Linguística Cognitiva vai em direção oposta ao que a Gramática Gerativa busca. Para o autor, a Gramática Gerativa tenta encontrar universais linguísticos inerentes ao sistema computacional que é capaz de gerar as sentenças de qualquer uma das línguas naturais com as quais um falante obtiver exposição suficiente no período adequado, e essa tentativa é feita por meio da observação de padrões estruturais, autônomos de qualquer 
significado associado. Já a Linguística Cognitiva procura observar padrões e processos responsáveis pela organização do conteúdo conceitual na linguagem.

Para a Linguística Cognitiva, o conteúdo conceitual é prioridade, e a linguagem é que se molda em torno desse conteúdo. Assim, as estruturas psicológicas dos indivíduos estariam ligadas a esses fenômenos conceituais. O léxico de uma língua seria o conjunto conceitual que se encaixa a um "esqueleto estrutural", e a variação nesse esqueleto é o que gera a diferença entre as línguas, pois são os elementos estruturais que organizam um conteúdo conceitual universal e invariável.

Assim sendo, pode-se dizer que, para a Semântica Cognitiva - e as teorias Cognitivistas em geral - não há uma Gramática Universal, mas uma "Conceitualização Universal", que varia dependendo das restrições estruturais de superfície - as formas linguísticas pronunciadas que a gramática de cada língua imprime sobre o conteúdo conceitual. Ou seja, primitivos semânticos como movimento, direção, figura, fundo, modo e causa são realizados por elementos de superfície como verbos, adposições, orações subordinadas, ou outros tipos de elementos secundários, os quais Talmy (2000) chama de satélites. A falta de correspondência de um-para-um entre os primitivos e os elementos de superfície é o que causa a variação.

A variação entre as línguas, para Talmy, se dá na maneira como cada uma delas aplica o seu "esqueleto sintático" no momento de representar determinados subeventos de um evento complexo maior. Para o autor, cada conceitualização mental de um acontecimento possui (pelo menos) dois subeventos. Esses subeventos, por sua vez, podem ser representados por uma ou por duas orações. Talmy chama esses subeventos de macroeventos. Cada conjunto de construções sintáticas de uma língua terá um determinado número de equivalências sintáticas para cada macroeventos. Essa variação de superfície, por sua vez, reflete o padrão tipológico da língua em observação. 
Existem dois tipos de subeventos dentro de um macroevento. Um deles é o evento principal, chamado de framing event (evento-moldura), enquanto a outra porção da conceitualização é chamada de co-evento. A manifestação superficial (sintática) de macroeventos - eventos-moldura e co-eventos - pode se dar tanto por duas orações distintas, quanto pelo que Talmy chama de uma "sentença básica complexa", a simples realização do evento moldura e do co-evento em uma única oração. No caso do inglês, sentenças com verbo de movimento (15) possuem um evento-moldura dividido entre movimento e locação, enquanto o co-evento pode denotar tanto Modo como Causa. Como se vê, esses traços são denotados em uma única oração, ao contrário de suas contrapartes do PB, quando as traduzimos.

Movimento
The pencil rolled off the table

'O lápis caiu da mesa rolando'

The pencil lay on the table

‘O lápis ficou apoiado

sobre a mesa'
The pencil blew off

the table.

`O lápis caiu da mesa

com um sopro'

The pencil stuck on the table (after I glued it).

‘O lápis ficou grudado na mesa (após eu colá-lo)'

(adaptado de TALMY, 2000, vol.2, p. 26) 
Talmy afirma que essa união entre o traço de modo e o verbo principal, chamada por ele de conflation, ocorre em línguas indo-europeias (com exceção das línguas românicas derivadas do latim), fino-húngaras, chinês, ojibwa, e warlpiri.

Além das afirmações de Talmy, é possível observar, pelas tentativas de tradução acima, que o PB e o inglês possuem padrões de conflation diferentes. Enquanto línguas com um padrão como o do inglês seguiriam o esquema em (16), com os traços de co-evento sendo realizados pelo verbo da oração principal, línguas românicas seguiriam o padrão em (17), com a direção lexicalizada no verbo e o modo representado no co-evento:

(16) Macroevento de movimento em inglês

[Figura Movimento Direção Fundo] $]_{\text {Evento de mov. }} \leftarrow$ Relação $[\text { [Evento] }]_{\text {Co-evento }}$

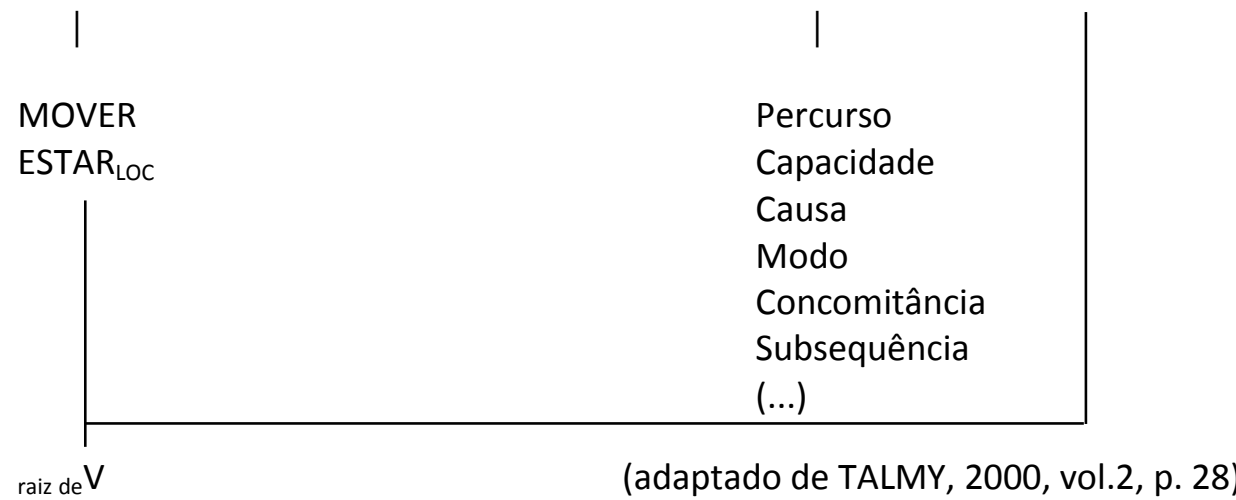

(17) Macroevento de movimento em espanhol

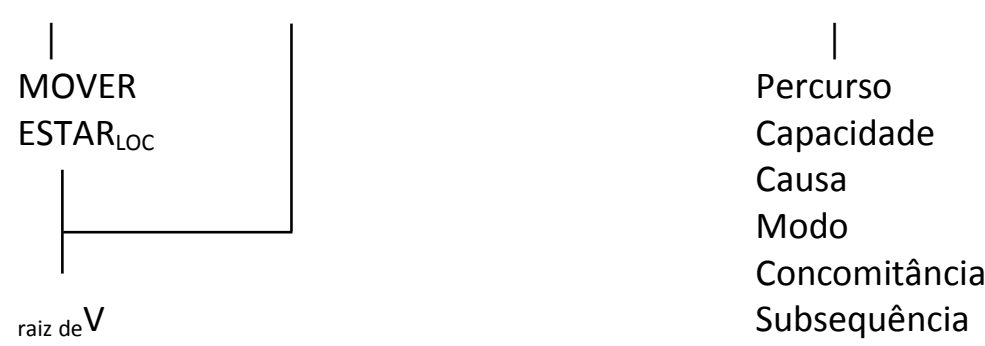

(...)

(adaptado de TALMY, 2000, vol.2, p. 49) 
Seguindo essa relação tipológica, Talmy propõe que exista um padrão de lexicalização ${ }^{5}$, ou seja, as línguas do mundo se enquadrariam (ao menos) em dois tipos de emolduração (framing): (i) emolduração pelos satélites (e.g.: inglês), (ii) e emolduração pelos verbos (e.g.: espanhol) ${ }^{6}$. Em línguas como o inglês, o modo seria expresso por meio de amálgama à raiz verbal, e direção seria expressa por meio de partículas, ou satélites. Já línguas como o espanhol (e o PB) teriam direção amalgamada (conflated) à raiz verbal. Assim, a tradução mais natural de (18), para os falantes de espanhol, seria (19):

(18)

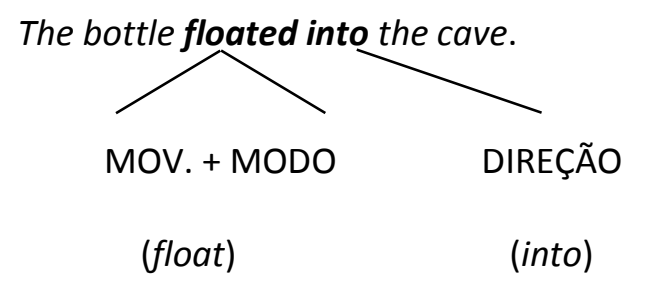

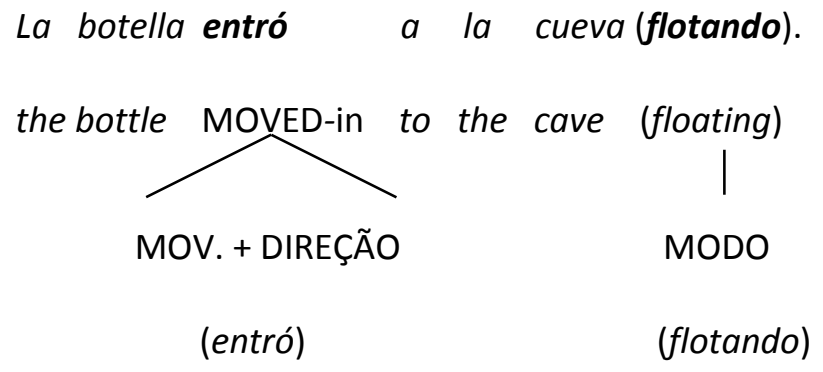

'A garrafa entrou na caverna boiando/foi boiando para dentro da caverna'

(adaptado de TALMY 2000, vol. 2, p. 49)

\footnotetext{
${ }^{5}$ Nesta tese, será proposto que quando (raiz de) $\mathrm{V}$ selecione parte do evento principal (as partes decompostas antes da seta) como em (16), toda a estrutura é codificada estruturalmente por um único vP. Quando o co-evento (à direita da seta) não for lexicalizado pelo verbo da sentença matriz (como em (17), ele será lexicalizado por meio de um adjunto de vP (ou seja, um satélite, pela terminologia de Talmy (2000)), ou por uma sentença encaixada, complemento do verbo matriz.

${ }^{6}$ Talmy (2000) não menciona o português brasileiro em seu trabalho. Porém, por questões de relação linguística, nesta tese, PB será considerado uma língua românica, enquadrando-se dentro do padrão de línguas emolduradas pelos verbos.
} 
Um dos objetivos desta tese é lidar com as generalizações tipológicas vistas acima, de modo a tentar fazer uma aproximação entre os padrões de lexicalização da Semântica Cognitiva e a proposta de parâmetros da Gramática Gerativa. Nesta tese, será proposta uma espécie de "tradução" das propriedades de organização de evento em termos sintáticos, nos quais as marcações paramétricas distintas entre PB e inglês sejam responsáveis por essas línguas apresentarem padrões diferentes de conflation e, consequentemente, de framing. Tendo isso em mente, como seria a transposição em termos de parâmetro para um esquema de conflation como (18) e (19), feito por Talmy para o inglês e para o espanhol, respectivamente?

Talmy (2000) propõe que, assim como as construções de movimento, construções de mudança de estado com estado resultante sejam um dos tipos de macroevento da estrutura conceitual que entrariam na distinção tipológica de moldura (framing) linguística. Baseado nessa relação, Barbosa (2008) propõe que construções resultativas estejam dentro desse esquema, e em variação tipológica com o inglês; nessa língua, mantém-se o conflation do modo no verbo, enquanto o estado resultante é lexicalizado nos satélites (o predicado secundário resultativo); no PB, o estado resultante é lexicalizado pelo verbo, e o modo pelos adjuntos (satélites), como se vê no esquema abaixo (cf. (20), (21), abaixo):

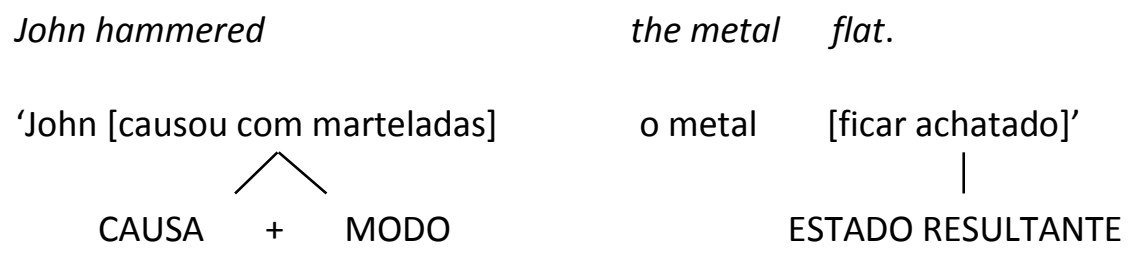

John flattened/caused the metal to become flat by hammering it. 'João achatou/deixou o metal achatado martelando-o.'

(BARBOSA, 2008, p. 51) 


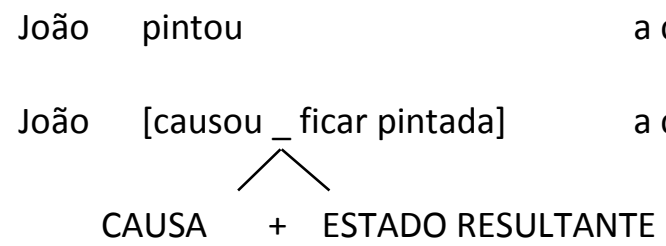

(adaptado de BARBOSA, 2008, p. 80)

A partir dessas relações tipológicas entre PB e inglês, é possível formar uma tabela que explicite a relação entre traços e a posição sintática potencial de realização (lexicalização, nas palavras de TALMY, 2000) destes:

(22) Tabela 1: Realização de traços de eventos complexos em PB e inglês

\begin{tabular}{|l|l|l|}
\hline Tipo de Traço & $\begin{array}{l}\text { Local de realização em línguas } \\
\text { emolduradas pelos satélites } \\
\text { (e.g.; inglês) }\end{array}$ & $\begin{array}{l}\text { Local de realização em línguas } \\
\text { emolduradas pelos verbos } \\
\text { (e.g.; PB) }\end{array}$ \\
\hline Modo & Evento principal (verbo) & Co-evento (adjunto/satélite) \\
\hline Causa & Evento principal (verbo) & Co-evento (adjunto/satélite) \\
\hline Direção (de movimento) & Co-evento (adjunto/satélite) & Evento Principal (verbo) \\
\hline $\begin{array}{l}\text { Estado resultante } \\
\text { (ou mudança de estado) }\end{array}$ & Co-evento (adjunto/satélite) & Evento Principal (verbo) \\
\hline
\end{tabular}

A partir dessa tabela, é possível pensar em um parâmetro que separe PB e inglês, com base nos tipos de traços envolvidos. Nesta tese, o traço de [modo] será o fator determinante para definir o mencionado parâmetro, apesar de Talmy sempre ter citado o traço de direção como o determinante para a distinção língua emoldurada pelo verbo/emoldurada pelos satélites, pois é onde o traço [direção] se encontra em cada língua o que determina o tipo de moldura ao qual pertence. 
Uma evidência para argumentar em favor da escolha do traço de [modo] seriam os dados em (23), que mostram que [direção] não parece ser o elemento mais relevante em macroeventos de movimento. Nesses verbos, parece que o traço semântico de [direção] é neutralizado, ou expresso por meio de uma redundância no elemento satélite:

(23)
a. Ela entrou pra dentro.
b. O cachorro saiu pra fora.
c. As crianças acabaram de subir pra cima.
d. Eu vou ter que descer lá pra baixo sozinho e buscar tudo?

Apesar de haver direção expressa nos elementos não-verbais, característica de línguas como o inglês, é mais natural no PB evitar o amálgama de [modo] nos verbos de construções como essas que sejam idênticas às expressões do inglês (cf. (24)a'-d', abaixo), o que leva a crer que, apesar de estar em distribuição tipológica com [modo], [direção] não seja o traço relevante para a observação tipológica (e, de acordo com a proposta a ser desenvolvida nesta tese, para a observação paramétrica) de línguas como inglês e PB.

(24) a. *Ela tropeçou pra dentro de casa.

a'. Ela entrou tropeçando em casa/ entrou em casa tropeçando.

b. *O cachorro rastejou pra fora.

b'. O cachorro saiu rastejando/ foi pra fora rastejando/ foi rastejando pra fora.

c. *As crianças acabaram de engatinhar pra cima.

$c^{\prime}$. As crianças foram lá pra cima engatinhando/subiram engatinhando.

d. *Eu vou ter que plantar bananeira lá pra baixo sozinho e buscar tudo?

d'. *Vou ter que ir lá pra baixo plantando bananeira e buscar tudo? 
A partir das evidências citadas acima, a escolha pelo traço de [modo] como relevante para a variação paramétrica a ser defendida nesta tese se justifica. Por conta dessa distinção, é proposto o parâmetro em (25), abaixo:

(25) Parâmetro de Emolduração

$$
\begin{aligned}
& \text { Uma língua denota [modo] em } v . \\
& \{\text { sim }\}=\text { inglês } \\
& \{\text { não }\}=\text { PB }
\end{aligned}
$$

Esse parâmetro captura as intuições por detrás das noções de Talmy (2000) de maneira que sua utilização pode explicar a formação de construções peculiares do inglês, nas quais o traço de [modo] é incorporado ao verbo. Os casos prototípicos em que essa incorporação de modo ocorre - entre outras construções - são as construções resultativas e das construções verbo+partícula. Essa discussão será retomada no próximo capítulo, e uma análise mais detalhada dessas construções a partir do Parâmetro de Emolduração será feita no capítulo 5 .

\subsection{Conclusão}

Neste capítulo, foi delimitada a noção de parâmetro que será considerada ao longo desta Tese, dentro dos moldes da Gramática Gerativa. Ainda é problemática a questão de se 
escolher propostas micro- ou macroparamétricas para definir o Parâmetro de Composição. Mesmo assim, a ideia de parâmetro parece ser compatível com propostas tipológicas ${ }^{7}$ fora do quadro teórico gerativista.

É com o intuito de unir as descobertas empíricas de ambos os vieses teóricos que este trabalho busca uma união capaz de tornar compatíveis os conceitos da Semântica Cognitiva, que, se traduzidos para as noções sintáticas em consideração, resultam em propriedades da estrutura argumental sintática da Gramática Gerativa. Nos próximos capítulos, essa aproximação se fará mais visível - e viável - para a explicação dos fenômenos que o PB mostra com relação ao Parâmetro de Composição, e, possivelmente, numa reformulação que o aproxime ao Parâmetro de Emolduração.

${ }^{7}$ Cf. Mateu (2001 et seq.). 


\section{Capítulo 2}

\section{Redefinindo e reclassificando o Parâmetro de}

\section{Composição}

Neste capítulo, o objetivo é mostrar que a cobertura empírica prevista pelo Parâmetro de Composição (SNYDER, 1995) deve, no mínimo, ser revista. Com base em argumentos teóricos e dados do PB, será mostrado que a gama ampla de predicados complexos elencada como participante do Parâmetro de Composição precisa ser revista, revelando uma necessidade de reanálise da proposta feita por Snyder. Dados de aquisição do PB confirmam a hipótese de que nem todos os predicados complexos deveriam estar ausentes em PB, fato que motiva a análise proposta nos capítulos seguintes. 


\subsection{Observando o Parâmetro de Composição translinguisticamente}

\subsubsection{Questões empíricas: o ponto de vista do $P B$}

O Parâmetro de Composição (SNYDER, 1995, 2001), conforme descrito na seção 1.1.1. (acima), mostra que o processo relevante para a distinção entre línguas como inglês e PB depende da possibilidade de a gramática dessas línguas permitir (ou não) a união de dois itens lexicais, formando nomes compostos $\mathrm{N}+\mathrm{N}$ ou predicados complexos, dependendo do tipo dos elementos combinados.

De acordo com o autor, os predicados complexos que aparecem na gramática de crianças adquirindo inglês concomitantemente aos compostos são: (i) verbo+partícula, (ii) causativos, (iii) construções com objeto duplo, (iv) construções perceptuais, (v) dativos com to e (vi) locativos com put (cf. (26), abaixo). Qualquer que seja a versão do parâmetro considerada, o argumento de Snyder é que, sempre que houver produtividade dos compostos $\mathrm{N}+\mathrm{N}$ em uma língua, a presença desses predicados complexos será garantida. Sugisaki \& Snyder (2002) também dizem que, além desses fenômenos, o fenômeno conhecido como isolamento de preposição (preposition stranding) também pode ser relacionado ao parâmetro, já que, de acordo com os autores, é um produto da formação verbo+partícula.

(26) a. Resultative: John painted the house red.

b. Verb-Particle: Mary picked the book up / picked up the book.

c. Make-causative: Fred made Jeff leave.

d. Perceptual report: Fred saw Jeff leave.

e. Put-locative: Bob put the book on the table. 
f. To-Dative: Alice sent the letter to Sue.

g. Double Object Dative: Alice sent Sue the letter.

(SUGISAKI; SNYDER, 2002; p.9)

Snyder (1995) propõe que a presença de predicados complexos em uma língua seja confirmada por meio de dois diagnósticos: (i) a produtividade de compostos $\mathrm{N}+\mathrm{N}$, e (ii) a possibilidade de formação de construções resultativas.

No caso do $\mathrm{PB}$, compostos do tipo $\mathrm{N}+\mathrm{N}$ não se mostram produtivos, e, em qualquer nome formado por mais de um N, a preposição tende a aparecer entre os dois elementos do "composto". Já no que diz respeito às construções resultativas, foi proposto em trabalho anterior (BARBOSA, 2008) que elas não existam nessa língua, especialmente pelo fato de que, como língua românica, PB se enquadraria no esquema de língua emoldurada pelo verbo (verbframed), de acordo com a tipologia de Talmy (2000), enquanto o inglês seria uma língua emoldurada pelos satélites (satellite-framed).

Por conta dessa assimetria nas respectivas representações adotadas para denotar sintaticamente a conceitualização de evento, a relação entre predicados complexos e a tipologia de Talmy (2000) já mostrada no capítulo 1 se torna ponto de partida para a comparação dos dados do Parâmetro de Composição; enquanto inglês apresenta amálgama de modo no verbo ((20), repetido aqui como (27)), PB não seria capaz de fazê-lo ((21), repetido aqui como (28)), fato que impediria, portanto, a ocorrência de construções resultativas nesta língua: 
(27)

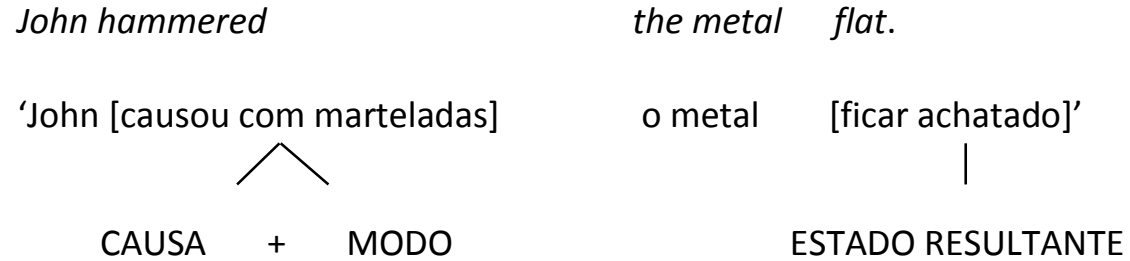

John flattened/caused the metal to become flat by hammering it.

'João achatou/deixou o metal achatado martelando-o.'

(BARBOSA, 2008, p. 51)

(28)

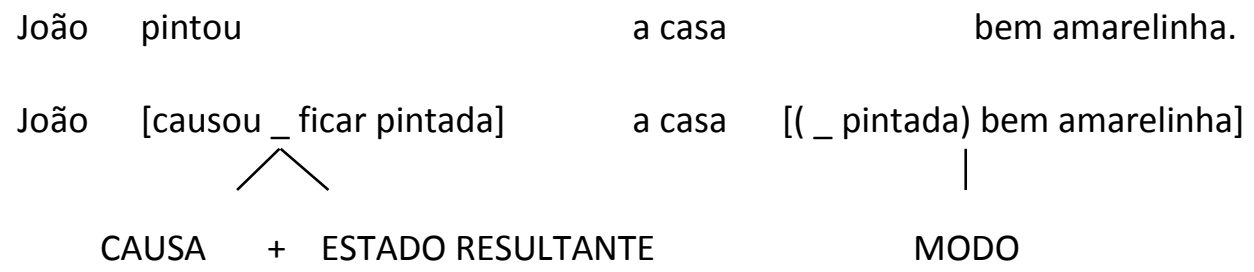

(adaptado de BARBOSA, 2008, p. 80)

À primeira vista, uma língua como PB seria marcada negativamente para o Parâmetro de Composição (SNYDER, 1995), e não seria capaz de formar predicados complexos como os mostrados em (26) (acima). Contudo, alguns argumentos de Snyder (op. cit.) para a formulação do Parâmetro de Composição poderiam ser considerados conflitantes quando observados sob um determinado ponto de vista.

Snyder (1995) apresenta evidências fortes de aquisição de compostos e predicados complexos como construções de objeto duplo e verbo+partícula em crianças falantes de inglês. Porém, o autor não mostra dados de aquisição de resultativas, apesar de considerar essas construções como representantes prototípicas dos predicados complexos, por apresentarem uma semântica específica, sem o risco de interpretações ambíguas. 
Aqui, surge um problema: quando se supõe que crianças falantes de inglês adquiram nomes compostos $\mathrm{N}+\mathrm{N}$ e predicados complexos ao mesmo tempo, espera-se que todos os tipos de predicados complexos apareçam ao mesmo tempo. Porém, construções resultativas não são mostradas nos dados de aquisição de Snyder (1995). Por outro lado, resultativas são as construções na qual o autor se baseia para formular seu parâmetro.

Se construções resultativas são predicados complexos, então elas também deveriam estar relacionadas empiricamente no Parâmetro de Composição. Com os dados que o trabalho de Snyder $(1995,2001)$ apresenta, a relação entre predicados complexos e construções resultativas, apesar de interessante do ponto de vista translinguístico, se torna indireta quando observada do ponto de vista da aquisição da linguagem, uma vez que a confirmação empírica esperada não é apresentada.

É verdade que construções resultativas apresentam uma semântica mais complexa, e que crianças possivelmente dependem de outros recursos que elas ainda não dominam para produzi-las, ao contrário de outros predicados complexos como verbo+partícula. Ainda assim, apenas resultativas são analisadas translinguisticamente por Snyder (op. cit.). Seguindo a lógica da análise de Snyder, se PB não possui resultativas, nem compostos $\mathrm{N}+\mathrm{N}$, era de se esperar que PB fosse uma língua marcada negativamente para o Parâmetro de Composição, e, como consequência, não apresentasse nenhum predicado complexo. Porém, observando as outras construções consideradas relevantes para o Parâmetro de Composição, pode-se argumentar que PB seja um problema para uma classificação uniforme daquilo que vem sendo chamado de predicados complexos pelo autor.

De acordo com o julgamento de falantes adultos de PB, as construções em (29), abaixo, são comuns e produtivas nessa língua, ao contrário do que a análise de Snyder (op. cit.) prevê. Como é possível observar nas glosas desses dados, não existe nenhuma diferença sutil 
na estrutura sintática ou na equivalência lexical/semântica entre as sentenças em inglês e sua tradução em PB:

(29) a. Fred made Jeff leave.

'Fred fez Jeff sair'

(Causativa)

b. Fred saw Jeff leave.

'Fred viu Jeff sair'

(Perceptual)

c. Alice sent the letter to Sue.

'Alice enviou a carta para Sue'

(Dativo com to)

d. Bob put the book on the table.

'Bob pôs o livro sobre a mesa'

(Locativo com put)

Além da questão da equivalência semântica na tradução das sentenças do inglês para o PB ser visível em (29), mas não em (30) (abaixo), são muito mais recorrentes na literatura de estudos translinguísticos afirmações sobre a não existência das construções em (30) nas línguas românicas - grupo ao qual pertence o PB - do que qualquer menção da inexistência

\footnotetext{
${ }^{8}$ Apesar de equivalentes na ordem sintática quando observadas palavra por palavra, as construções causativas e perceptuais do inglês tratam de fenômenos de marcação excepcional de Caso (ECM), enquanto os fenômenos do PB aparentam serem constituídos de duas camadas flexionais TP (matriz e infinitivo). Mesmo assim, esses predicados complexos possuem dois domínios verbais (de vP), e não são do mesmo tipo de predicado complexo relevante para a discussão, como ficará mais claramente explicitado a partir da seção 2.2.1.
} 
das construções em (29), fato que por si só já causa estranhamento sobre o rol de fenômenos postulados por Snyder (op. cit.) como integrantes do Parâmetro de Composição:

(30)
a. John hammered the metal flat/to pieces.
John martelou o metal plano/achatado/em pedaços
'John martelou o metal até ele ficar plano/achatado/em pedaços / João fez o metal ficar plano/achatado em pedaços de tanto martelá-lo'

(Resultativa)

$\begin{array}{llll}\text { b. The man } & {[\text { who }]_{a}} & \text { you were talking about } t_{a} \\ \text { O homem } & \text { [quem }]_{a} & \text { você estava falando sobre } t_{a} \\ \text { is } & \text { here } & \\ \text { está } & \text { aqui }\end{array}$

'O homem [sobre quem] $]_{a}$ você estava falando $t_{a}$ está aqui'

(Isolamento de Preposição)
c. John gave Mary a new house.
John deu Mary uma casa nova
'John deu uma casa nova para Mary / John deu para Mary uma casa nova'
$c^{\prime}$. * João deu Maria uma casa nova.
c". João deu pra Maria uma casa nova.
(Objeto duplo)
d. John picked
the book up
picked up the book.
John pegou
o livro cima
'John pegou/apanhou o livro'
(Verbo+partícula) 
Cabe, neste momento, fazer algumas observações acerca das idiossincrasias presentes em cada construção, bem como dos fatores que as aproximam. Pensando na questão de "compartilhamento de argumentos", a divisão entre (29) e (30) parece, em um primeiro momento, problemática. Ao observar a relação dos predicados complexos e dos argumentos, é possível encontrar três tipos de relações argumentais:

Relações entre argumentos e predicadores nos predicados complexos

(i) Dupla atribuição temática ${ }^{9}$ : Os dois elementos que formam o predicado complexo atribuem papel temático ao argumento interno (resultativas (30)a, verbo+partícula (30)d, isolamento de preposição (30)b);

(ii) Dupla complementação: O verbo atribui papel temático tanto para o argumento interno direto (aquele que recebe Caso acusativo) quanto para o argumento interno indireto, geralmente mediado por uma preposição (dativos com to (29)c, locativos com put (29)d, objeto duplo (30)c);

(iii) Predicação encaixada: O verbo atribui papel temático para toda a oração encaixada (causativas (29)a, perceptuais (29)b).

Além desses fatos, a categoria gramatical dos elementos que podem combinar-se ao verbo para formar predicados complexos é vasta. Utilizando a separação feita em (31), é

\footnotetext{
${ }^{9}$ A nomenclatura aqui proposta é apenas um mecanismo descritivo do comportamento sintático e semântico observado nas construções envolvidas no Parâmetro de Composição. A formalização das estruturas em que esses predicados complexos ocorrem e quais suas estruturas serão explicitadas ao longo da tese.
} 
proposta uma nova nomenclatura para esses grupos, cujas categorias gramaticais envolvidas são apresentadas em (32):

(32) Categorias gramaticais que ocorrem nos predicados complexos

(i) Predicados complexos "puros" (compartilham o argumento interno):

a. $\quad \mathrm{V}+\mathrm{A}$ : resultativas (30)a;

b. $\quad$ V+P: verbo+partícula (30)d, isolamento de preposição (30)b;

(ii) Predicados pseudo-complexos (um dos predicados é, de fato, argumento do verbo):

c. V+PP: dativos com to (29)c, locativos com put (29)d, resultativas $(30) c^{10}$;

d. V+DP: objeto duplo ${ }^{11}(30)$ c.

(iii) Predicados complexos encaixados (um dos predicados faz parte de uma oração encaixada):

e. V+TP: causativas (29)a, perceptuais (29)b;

Por outro lado, as construções podem ser distinguidas a partir dos seguintes fatores: (i) número de núcleos predicando do objeto direto, (ii) número de camadas verbais (VPs) na estrutura, e número de "eventos" no sentido de Talmy, ou seja, macroeventos. Essas propriedades podem ser observadas abaixo tanto na tabela 2 , em (33), que diz respeito aos dados em (29), quanto na tabela 3, em (34), que aponta propriedades dos dados em (30):

${ }^{10}$ Apesar de (30) ter um AP denotando o estado resultante, construções resultativas podem ser expressas tanto na formação $V+D P+A P$ quanto na formação $V+D P+P P$, com o PP sendo um introdutor do estado resultante, o qual pode ser encabeçado tanto por uma preposição plena quanto por uma partícula. Porém, esses PPs sempre denotam o estado resultante da ação denotada pelo verbo, ao contrário dos PPs argumentos dos predicados complexos de dupla complementação. Para mais detalhes sobre a formação de construções resultativas, cf. Barbosa (2008) e as referências lá citadas, bem como o capítulo 5 desta tese.

${ }^{11}$ Mais adiante, será argumentado que a relação de predicação complexa em construções de objeto duplo não é direta, o que permitirá excluir a hipótese de predicados complexos do tipo V+DP nesses casos. 
(33) Tabela 2: Propriedades de predicação de predicados complexos do inglês que não possuem equivalentes no $\mathrm{PB}$

\begin{tabular}{lllll}
\hline Construção & $\begin{array}{l}\text { Formadores do } \\
\text { predicado } \\
\text { complexo }\end{array}$ & $\begin{array}{l}\text { Núcleos } \\
\text { verbais }\end{array}$ & $\begin{array}{l}\text { Núcleos } \\
\text { predicadores }\end{array}$ & $\begin{array}{l}\text { Argumentos } \\
\text { internos }\end{array}$ \\
\hline Resultativa & hammer + flat & hammer & hammer + flat & metal \\
$\begin{array}{l}\text { Isolam. de } \\
\text { preposição }\end{array}$ & talk + about & talk & talk + about & the man \\
$\begin{array}{l}\text { Verbo+partícula } \\
\text { pbjeto duplo }\end{array}$ & gick + up & pick & pick + up & the book \\
\hline
\end{tabular}

Na tabela em (33), é possível observar que os predicados complexos que não ocorrem em inglês, apesar de dois elementos predicando do objeto direto, apresentam apenas um núcleo verbal, e um argumento interno, com exceção da construção de objeto duplo, cujo argumento interno possui propriedades de predicador ao mesmo tempo em que é argumento do verbo.

Já no caso do PB os dados não se comportam de maneira uniforme. É possível separar os dados em dois grupos: (i) predicados complexos encaixados (construções causativas e construções perceptuais) e (ii) predicados pseudo-complexos (construções dativas e construções locativas), como é possível ver na tabela (34), abaixo: 
(34) Tabela 3: Propriedades de predicação de predicados complexos do inglês que possuem equivalentes no $\mathrm{PB}$

\begin{tabular}{|c|c|c|c|c|}
\hline Construção & $\begin{array}{l}\text { Formadores do } \\
\text { predicado } \\
\text { complexo }\end{array}$ & $\begin{array}{l}\text { Núcleos } \\
\text { verbais }\end{array}$ & $\begin{array}{l}\text { Núcleos } \\
\text { predicadores }\end{array}$ & Argumentos internos \\
\hline Causativa & $\begin{array}{l}\text { make + leave } \\
\text { fazer +sair }\end{array}$ & $\begin{array}{l}\text { make + leave } \\
\text { fazer + sair }\end{array}$ & $\begin{array}{l}\text { make + leave } \\
\text { fazer + sair }\end{array}$ & \\
\hline Perceptual & $\begin{array}{l}\text { see + leave } \\
\text { ver + sair }\end{array}$ & $\begin{array}{l}\text { see + leave } \\
\text { fazer + sair }\end{array}$ & $\begin{array}{l}\text { see + leave } \\
\text { ver + sair }\end{array}$ & \\
\hline Dativa & $\begin{array}{l}\text { send + to Sue } \\
\text { enviar + para Sue }\end{array}$ & $\begin{array}{l}\text { send } \\
\text { enviar }\end{array}$ & $\begin{array}{l}\text { send } \\
\text { enviar }\end{array}$ & $\begin{array}{l}\text { a letter + Sue } \\
\text { uma carta + Sue }\end{array}$ \\
\hline Locativa & $\begin{array}{l}\text { put }+ \text { on the table } \\
\text { por + sobre a mesa }\end{array}$ & $\begin{array}{l}\text { put } \\
\text { por }\end{array}$ & $\begin{array}{l}\text { put } \\
\text { por }\end{array}$ & $\begin{array}{l}\text { the book + the table } \\
\text { o livro + a mesa }\end{array}$ \\
\hline
\end{tabular}

Enquanto os dados em (33) apresentam um mesmo comportamento quando observadas suas propriedades de predicação e suas relações argumentais, as construções em (34) mostram que, enquanto os predicados complexos encaixados não apresentam qualquer argumento interno, os predicados pseudo-complexos possuem um argumento que compõe a predicação complexa sobre seu argumento interno. Ou seja, nenhum dos dois tipos apresenta uma configuração compatível com o grupo de predicados complexos puros ${ }^{12}$.

Como é possível notar pelas divisões mostradas acima, é muito difícil achar critérios explícitos e unânimes que agrupem de maneira uniforme os dados em (29) e (30). Apesar disso, existe uma clara divisão conceptual em três grupos, de acordo com as suas propriedades sintático-semânticas (i.e., predicados complexos (i) puros, (ii) pseudo-complexos e (iii) encaixados). Por outro lado, a divisão dos dados nas tabelas separa construções ausentes em PB (33) de construções presentes em PB (34). Apesar da força descritiva dos três grupos de predicados complexos propostos, a distinção empírica prevalece como prioridade, e, se PB não

\footnotetext{
${ }^{12}$ Apesar de pertencer à classe dos predicados pseudo-complexos, a construção de objeto duplo não ocorre em PB. No capítulo 4, a explicação para essa impossibilidade será derivada a partir de uma análise independente à dos predicados complexos puros.
} 
admite a ocorrência das construções em (30), a seguinte questão se mantém ${ }^{13}$ : existe de fato alguma relação entre a aquisição dos fenômenos em (29) e o Parâmetro de Composição?

Para responder essa questão, dois caminhos podem ser tomados: (i) as construções em (29) do PB não possuem a mesma interpretação semântica ou estrutura sintática das suas "equivalentes" em inglês; (ii) as construções em (29) do PB são idênticas às do inglês em interpretação semântica e estrutura sintática, e não fazem parte do Parâmetro de

\section{Composição.}

Seja qual for a resposta dada para a pergunta, qualquer análise desses predicados complexos deve levar em conta a grande variedade de categorias e tipos de contextos de predicação que os dados tanto de (29) quanto de (30) apresentam. Snyder (2001), por exemplo, segue a primeira alternativa ${ }^{14}$, e aponta o fato de que alguns desses fenômenos sintáticos em línguas românicas aparentam semelhanças com o inglês, mas são diferentes.

\footnotetext{
“Duas ressalvas estão em questão aqui. Primeiro, deve-se notar que línguas românicas fornecem ao menos contrapartes superficiais para algumas das outras construções do inglês $(1)^{15}$ que receberam análise de predicados complexos. Isso pode simplesmente indicar que algumas das formas de superfície em (1) são ambíguas em estrutura. Além disso, deve-se notar que línguas germânicas, que geralmente se assemelham ao inglês em permitirem a maioria das construções em (1), não necessariamente permitem todas as construções. Por exemplo, a construção de objeto duplo (acusativo duplo) do inglês (1g) não possui uma contraparte direta em alemão como ilustrado em (i), onde marcação morfológica de dativo (não marcação de acusativo) é exigida no artigo definido do objeto indireto. Portanto, mesmo línguas que permitam predicados complexos em geral, podem não permitir construções de predicados complexos específicas por razões independentes.
}

\footnotetext{
${ }^{13}$ Apesar de a divisão empírica ser tomada como base para a distinção dos fenômenos relacionados ao Parâmetro de Composição, a questão da divisão entre predicados complexos puros, pseudo-complexos e encaixados será explicada (e relacionada à divisão binária inicial) ao longo do trabalho.

${ }^{14}$ Snyder (2001) não menciona explicitamente o PB na sua discussão. Porém, como língua românica, pode-se inferir que PB faria parte do grupo de línguas que não possuem a mesma interpretação do inglês, já que PB seria marcado negativamente para o Parâmetro de Composição, conforme discutido acima.

${ }^{15}$ A numeração citada é referente ao texto de onde a citação foi extraída. Ainda assim, os dados que o autor menciona são os mesmos de (29) e (30), acima.
} 
(i)

*Hans hat den Mann das $\quad$ Geld gegeben
Hans has the-Acc man the-Acc money given
'Hans gave the man (Acc.) the Money (Acc.).'

(SNYDER, 2001, p. 37, nota 3, tradução minha)

Apesar dessa afirmação, Snyder não dá nenhum argumento para que essas construções sejam consideradas diferentes em cada uma das famílias linguísticas em questão. Lembrando que alemão e inglês pertencem a uma mesma família, a ausência de construções de objeto duplo em alemão é inesperada, já que línguas de outra família - nesse caso em específico, as línguas românicas - são aquelas sobre as quais Snyder se preocupa em argumentar de fato. Por conta disso, como seria possível explicar que existe um mesmo tipo de variação entre línguas de uma mesma família como inglês e alemão, de um lado, e entre línguas de famílias diferentes, como germânicas e românicas, se a questão acima for considerada?

Pensando nas diferenças entre variação micro- e macroparamétrica, é possível argumentar a favor do fato apontado por Snyder (2001), acima, com base na seguinte afirmação feita por Baker (2008b):

“É possível que dois dialetos possam diferir em um macroparâmetro, mas as diferenças se cancelam amplamente na superfície por conta de uma série de escolhas microparamétricas que as línguas fazem".

(BAKER, 2008b, p. 357, tradução minha) 
De acordo com a afirmação feita por Baker, nada impediria que um microparâmetro que não seja relacionado em nada ao Parâmetro de Composição, mas que afete esta construção em específico - possa ser responsável pela ausência de construções de objeto duplo $^{16}$. Assim, o alemão seria capaz de ser considerada uma língua marcada positivamente para o Parâmetro de Composição, mesmo sem ser capaz de apresentar produtividade em todas as construções referentes ao parâmetro. Mas, e no caso de uma língua que não pode ser considerada um dialeto, ou que apresente uma relação mais macroparamétrica do que a relação entre inglês e alemão? É pouco provável que escolhas microparamétricas expliquem variabilidade de construções possíveis quando se compara inglês e PB, pois, além de serem línguas de famílias distintas, a variação que é apontada acima diz respeito à metade dos fenômenos que Snyder (1995) aponta como relevantes para o Parâmetro de Composição, sem contar a diferença nos nomes compostos das duas línguas.

Além disso, ao contrário dos dados do inglês em (30), que mostram clara evidência de manifestação sintática de um determinado conteúdo semântico de maneira diferente da do PB, os dados em (29) aparentam ser idênticos aos do inglês. Em última instância, ainda que os argumentos acima expostos não sejam suficientes para excluir a possibilidade (i) como alternativa para explicar as diferenças entre os paradigmas (29) e (30), seria necessário argumentar a favor de uma análise que aponte quais os traços que poderiam incluir (29) ao Parâmetro de Composição.

Aqui, ao contrário do que propõe Snyder $(1995,2001)$, o caminho em (ii) será seguido, tomando em consideração as questões de variação paramétrica mencionadas, além de apresentado um argumento empírico que é mostrado na próxima seção: um estudo

\footnotetext{
${ }^{16}$ Na seção seguinte, será feita uma comparação entre construções causativas do português brasileiro e do português europeu. Com base nessa comparação, será mostrado que relações microparamétricas podem afetar o que, aparentemente, seria um contra argumento para uma análise macroparamétrica envolvendo causativas em PE, que, apesar de ser uma língua românica como PB, apresenta comportamento sintático distinto nas suas construções causativas. Talvez, o que ocorre entre inglês e alemão possa ser explicado de maneira semelhante (i.e., por uma análise microparamétrica).
} 
longitudinal de aquisição, que se acredita trazer contribuições importantes para a argumentação contra a relevância dos fenômenos em (29) para o Parâmetro de Composição.

2.1.1.1. Aquisição de predicados complexos no PB: um estudo-piloto

Além dos resultados de análises translinguísticas, os trabalhos de Snyder $(1995,2001)$ se apoiam fortemente em estudos de aquisição para comprovar a hipótese do Parâmetro de Composição. Os resultados desses estudos apontam uma forte correlação de tempo de aquisição entre os predicados complexos apontados em (29) e (30), acima, e compostos do tipo $\mathrm{N}+\mathrm{N}$, em crianças falantes de inglês. Como apontado na seção anterior, os resultados dos estudos de aquisição não levam em conta construções resultativas, o que se torna um problema para Snyder (1995), já que o autor toma essas construções como diagnóstico para determinar se uma língua possui ou não predicados complexos. Com essa ausência de evidência de aquisição, os resultados de sua relação translinguística ficam enfraquecidos, pois apenas a relação entre compostos e resultativas observada, o que força uma correlação entre resultativas e outros predicados complexos sem base em evidências empíricas palatáveis.

Ainda que o Parâmetro de Composição estivesse correto, esperaria-se que uma língua que não possui construções resultativas, como $\circ \mathrm{PB}$, por exemplo ${ }^{17}$, não apresentasse nenhuma das construções de (29) ou (30), acima. Só que, conforme vem sendo argumentado até aqui, construções em (29) são produtivas em PB, e, sob um primeiro olhar, aparentam ser

\footnotetext{
${ }^{17}$ Cf. Barbosa (2008).
} 
idênticas às mesmas construções do inglês. Se essas construções estiverem presentes na gramática de falantes de PB em estágio de aquisição, e tiverem relação com o surgimento de nomes compostos $\mathrm{N}+\mathrm{N}$ nessa língua ${ }^{18}$, então haverá evidência empírica para uma redefinição do Parâmetro de Composição, ou ainda, um questionamento sobre sua validade.

Para confirmar a hipótese de que os dados em (29), acima, estão presentes desde cedo na gramática de falantes de PB, Barbosa \& Simioni (2009) fizeram um estudo longitudinal de aquisição com base na observação de duas crianças, $R$ e $L$, no período de $1 ; 9$ e $4 ; 11^{19}$. Os autores notam que tanto nomes compostos preposicionados quanto as construções em (35) a (38) surgem a partir dos 2;0 anos, o que é extremamente próximo ao período de aquisição de compostos em crianças adquirindo inglês, que, de acordo com Snyder (1995), ocorre entre 1.87 e 2.59. Abaixo alguns dados, separados por tipo de construção:

$$
\underline{\text { Dativos com to }}^{20}
$$

a. Dá t[c]omida $\mathrm{p}(\mathrm{r}) \mathrm{o}$ pintinho.

b. O Ped(r)inho deu pe(i)ss[x]inho p(r)á mim.

c. Me dá a o(u)tra ponte.

18 Por enquanto, parece estranho fazer uma comparação entre compostos do PB e do inglês, especialmente porque a possibilidade de compostos $\mathrm{N}+\mathrm{N}$ sem a presença de uma preposição é crucial para a proposta de Snyder (1995). Mais adiante, porém, será mostrado que a diferença entre compostos não é tão grande como parece, e a motivação para apontar a relação de aquisição entre compostos do PB e os supostos predicados complexos de (29) terá uma explicação adequada dentro da análise a ser proposta.

${ }^{19}$ Snyder (1995) usa uma notação diferente da utilizada por Barbosa \& Simioni (2009) para determinar a idade das crianças que fazem parte do seu conjunto de dados. Enquanto sua notação é de média matemática (1.87 significa (aproximadamente) 1 ano e 10 meses), a notação aqui usada é com base na idade absoluta (1;9 significa 1 ano e 9 meses). Além disso, Snyder faz um estudo estatístico refinado para mostrar as relações entre as construções. Neste estudo, apenas correlações aproximadas são mostradas, pois um estudo estatístico seria pouco eficiente, dado o número reduzido de crianças analisado no experimento.

${ }^{20}$ Nos dados acima, a seguinte convenção foi adotada: vogais, consoantes ou sílabas não pronunciadas pela criança são representadas entre parênteses. Consoantes pronunciadas com seu ponto/modo de articulação trocado são representadas pela consoante correta logo em seguida, entre colchetes []. Já as vogais excedentes na fala são representadas dentro de chaves \{\}. Prolongamentos de sílabas são representados por reticências (...). Agradeço a Raquel Santos e Elaine Grolla por terem permitido acesso aos dados levantados em (35)-(39). 
a. Vamo pega(r) verdu(ra) $p(r)$ a po(r) aqui.

(R., 2;0.20)

b. Então eu vou da(r) uma enfiada disso na p(r)esilha da Daniela.

(R., 2;9.16)

c. (Es)se aqui não é de bota(r) ali.

(L., $2 ; 0.7)$

d. Põe aqui, mamãe.

(L., $2 ; 1.25)$

e. Você pode coloca(r) aqui na cadeira.

$(L ., 4 ; 0.8)$

(37)

\section{$\underline{\text { Perceptuais }}$}

a. Tô escutan(d)o o home fala(r).

b. Vem ve(r) eu corre(r) que eu pulo.

(R., 3;0.7)

c. Quero ve(r) os anõezinhos caíra[e]m.

(R., 3;0.18)

(38) Causativos

a. É quem que fez\{e\} fica(r) aqui.

b. Deixa eu passa(r), mamãe, deixa?

c. É quando você quise(r) que ela ande, você tem que faze(r) ela anda(r) assim.

(L., 4;6.13)

(39) Compostos preposicionados
a. galinha do b[v]id[z]i(...)nho
(R., 2;0.20)
b. um pedacinho de bolo
(R., 2;0.20)
c. tu(do) caz[r]a de b(r)uxa.
(L., 2;2.28) 
Levando os dados acima em consideração, fica claro que o PB, como língua românica, pode ser apresentado como contraevidência empírica para a postulação de que os dados em (29) (do mesmo tipo de (35) a (38), acima) sejam, de fato, relevantes para o Parâmetro de Composição. Conforme o próprio Snyder nota (1995, p. 39), há uma "explosão" na gramática da criança, e várias construções emergem durante o período de aquisição dessas construções. Ainda assim, é possível acreditar que esse aumento de complexidade na gramática da criança se dê mais por fatores maturacionais, e que atrelar um número tão grande de construções a um único parâmetro apresenta um risco muito grande de relacionar construções que não possuem relação paramétrica entre si, fato que este estudo tentará comprovar.

Nas seções a seguir, o objetivo será mostrar que, observando todos os predicados complexos até aqui mencionados, as construções que aparecem em PB são de natureza distinta das construções do inglês para as quais não se encontram equivalentes em PB, se forem levados em consideração fatos como a estrutura de eventos dessas construções, relações temáticas e de perspectiva de evento.

2.1.2. Observando a perspectiva de evento: fatores de classificação de predicados complexos 2.1.2.1. Talmy (2000): Emolduração e a estrutura de (macro)eventos

Nas seções anteriores, foram apresentados argumentos empíricos e discutidos possíveis fatores que apontam a favor de uma divisão entre as construções consideradas 
predicados complexos, conforme proposto em Snyder (1995). Nesta seção, o objetivo será argumentar em favor da possibilidade de que fatores como a estrutura informacional, ou a perspectiva de evento, sejam capazes de trazer à tona importantes insights sobre a organização das estruturas sintáticas em questão, bem como para contribuírem na reformulação do Parâmetro de Composição. Assim sendo, os trabalhos de Talmy (2000) serão tomados como base para a análise aqui apresentada, e, nos mesmos moldes de trabalhos anteriores (cf. BARBOSA, 2008, 2009), será feita uma aproximação das noções da teoria da Semântica Cognitiva ${ }^{21}$ e da Gramática Gerativa, estabelecendo equivalências entre as maneiras pelas quais a Gramática Gerativa poderia explicar a representação cognitiva de um evento mental - conforme a proposta da Semântica Cognitiva - e a denotação deste evento por meio de suas representações sintáticas.

Conforme mencionado anteriormente, Barbosa (2008) mostra que a diferença entre os framings (emoldurações) dos eventos em inglês e PB são responsáveis pela impossibilidade de formação de construções resultativas nessa língua. Em trabalho anterior (BARBOSA, 2009), investigou-se a possibilidade de que a formação de predicados complexos estivesse relacionada à possibilidade de denotar mais de uma eventualidade (ou co-evento, nos termos de TALMY, op. cit.) em uma única estrutura sentencial (ou ainda, em um único VP).

Para Talmy (2000), a representação cognitiva seria formada a partir daquilo que o autor chama de "molde conceitual" (o sistema lexical) sobre um "esqueleto estrutural" (o sistema gramatical). Os macroeventos se dividem entre (i) framing events (eventos-moldura, ou eventos principais) e (ii) os co-eventos. Esses macroeventos são representados na superfície (sintaticamente) por aquilo que Talmy chama de uma "sentença básica complexa". Ou seja, nessas sentenças, o evento principal (evento moldura) seria o evento de figura, enquanto o co-

\footnotetext{
${ }^{21}$ Para uma descrição da teoria da Semântica Cognitiva, cf. Talmy (2000), Barbosa (2008). Para exemplos de aplicação "híbrida" entre Gramática Gerativa e Semântica Cognitiva, cf. Mateu (2001), Barbosa (2008).
} 
evento seria o evento de fundo, mantendo uma relação de suporte com o anterior. Em (40) é possível ver o esquema conceitual (universal) do macroevento e a distribuição prototípica dos tipos de eventualidades que nele ocorrem:

(40) Estrutura conceitual do macroevento

([Corrente Agente-causal]) [Evento] $]_{\text {evento-moldura }}$

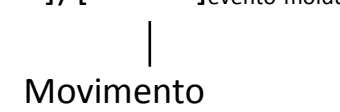

Contorno temporal

Mudança de estado

Correlação de ações

Percepção

(...)

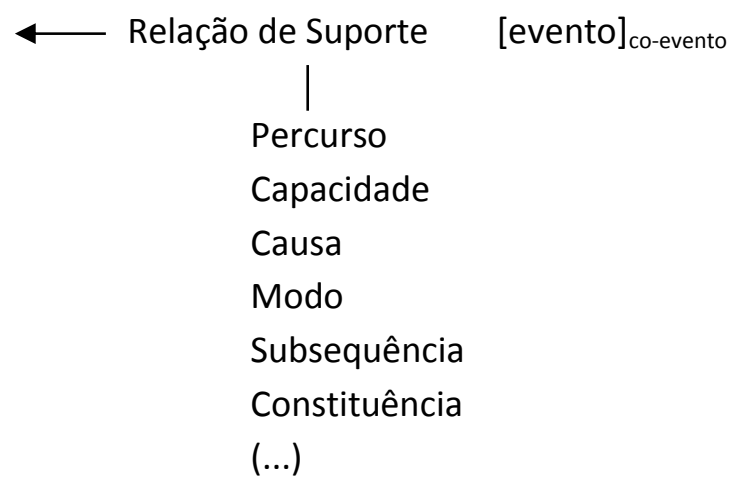

(TALMY, 2000, vol.2, p. 221, tradução minha)

Será seguida aqui a proposta de Mateu \& Rigau (1999) para o mapeamento das propriedades de amálgama e de emolduração de eventos proposta por Talmy (2000). Os autores propõem que seja possível efetuar uma tradução das propriedades descritivas da semântica das construções mencionadas por Talmy (op. cit.) em termos sintáticos, alegando, com base em Snyder (1995), que uma análise em termos puramente semânticos não seria explicativa, já que a 'variação paramétrica' nesses processos envolvem a morfossintaxe, e não apenas a variação semântica. Assim, traços como originador, figura e fundo teriam posições sintáticas preestabelecidas, como (41): 
(41)
a. Originador
especificador de $v \mathrm{P}$
b. Figura
especificador de $\mathrm{P}$
c. Fundo
complemento de $\mathrm{P}$

(MATEU; RIGAU, 1999, p. 9, tradução minha)

Apoiados nas propostas de Hale \& Keyser $(1993,1997,1998)$, os autores afirmam que as representações de estrutura argumental de uma sentença como (42), abaixo, apresentariam as informações lexicais em (43), formando a estrutura vista em (44):

(42)
Sue danced into
the room.
Sue dançou em+para a sala
"Sue dançou até entrar na sala/ entrou na sala dançando"

(MATEU; RIGAU, 1999, p. 10)

(43) dance

matriz fonológica.

V (<relação

causal)

$v[N$ V] go

into

Sue

room

$\begin{array}{llll}\text { s/ mat. fon. } & \text { mat. fon. } & \text { mat. fon. } & \text { mat. fon. } \\ V \text { (<relação } & P \text { (<relação } & \mathrm{N} \text { (< elemento } & \text { (< elemento } \\ \text { transicional) } & \text { espacial) } & \text { não-relacional) } & \text { não-relacional) } \\ & \text { P [P P] } & & \end{array}$

(MATEU; RIGAU, 1999, p. 10, tradução minha) 


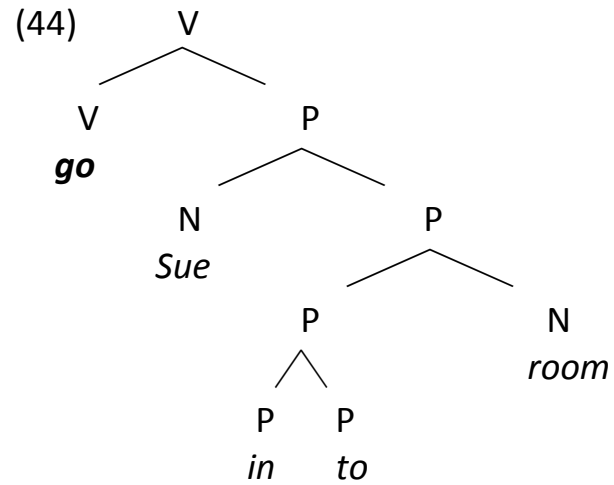

(MATEU; RIGAU, 1999, p. 11)

Estendendo a proposta de Mateu \& Rigau para as representações de Talmy (2000) como a mostrada em (40), por exemplo, será proposto nesta tese que o evento-moldura corresponda a $v(\mathrm{P})$, enquanto o co-evento corresponda a uma projeção funcional selecionada por v - seja essa projeção parte de uma nova oração (TP, CP) ou algo semelhante a uma small clause (doravante mini oração). Uma propriedade importante a ser lembrada é que o eventomoldura é sempre denotado pelo verbo, (núcleo de v). Com isso, as variações tipológicas devem estar centralizadas nos traços realizados no verbo, dependendo do seu padrão de lexicalização.

O ponto mais importante a ser levado em conta nessa proposta de equivalência é a relação entre o evento-moldura e o co-evento. Na próxima seção, será feita uma tentativa de explicar por que, no caso das resultativas e verbo+partícula, a relação de suporte é lexicalizada no verbo, apesar de fazer parte do co-evento. 
2.1.2.2. Questões translinguísticas acerca dos macroeventos e a classificação dos predicados complexos relevantes ao Parâmetro de Composição

Como já mencionado no capítulo 1, Talmy (2000) parte da observação sobre sentenças com verbo de movimento e mostra que línguas como o inglês podem apresentar um macroevento principal com um traço de 'Movimento', dividido entre "movimento" e "locação", enquanto o co-evento poderia tanto denotar um evento de 'Modo' ou de 'Causa' ((15), repetido aqui em (45)) (BARBOSA, 2008, p.44):

Modo

Causa

Movimento

The pencil rolled off the table

The pencil blew off

the table.

'O lápis caiu da mesa rolando'

‘O lápis caiu da

mesa com um sopro'

Locação

The pencil lay on the table

The pencil stuck on the

table (after I glued it).

‘O lápis ficou apoiado

‘O lápis ficou grudado

sobre a mesa'

na mesa (após eu colá-lo)'

(TALMY, 2000, vol.2, p. 26, tradução minha) 
No inglês, o verbo é capaz de expressar um traço de evento-moldura e um traço de relação de suporte codificados em um único item lexical - no caso, o verbo. Para o autor, esse tipo de amálgama ocorre nas seguintes línguas: indo-europeias (com exceção das línguas românicas derivadas do latim), fino-húngaras, chinês, ojibwa, e warlpiri. Apesar de apresentar uma codificação mais complexa no verbo, essas línguas são denominadas satellite-framed (emolduradas pelos satélites), segundo Talmy (2000), pelo fato de que o traço de direção - o mais relevante para a tipologia do autor - é preferencialmente codificado em um satélite (uma partícula ou um adjunto). Para essas línguas, o esquema que expressa esse amálgama de traços pode ser representado da seguinte maneira para o inglês, uma das línguas que permitem esse tipo de amálgama (conflation): Macroevento de movimento em inglês (língua emoldurada pelos satélites)

[Figura / Movimento / Direção / Fundo] Evento de movimento<smiles>C=C</smiles>

MOVER ESTAR $_{\text {LOC }}$ $\downarrow$

raiz de $\underline{\mathbf{V}}$ $\longleftarrow$ Relação

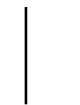

Percurso

Capacidade

Causa

Modo

Concomitância

Subsequência

(...)

(adaptado de TALMY, 2000, vol.2, p. 28)

No caso das línguas românicas, por exemplo, a direção tende a aparecer lexicalizada no verbo, e o modo é representado por outro item lexical, um satélite - adjunto ou partícula, dependendo da língua em questão -, que denota o co-evento. Por isso, línguas compatíveis com essa classificação tipológica são consideradas verb-framed (emolduradas pelo verbo) (47): 
[Figura / Movimento / Direção / Fundo] Evento de movimento
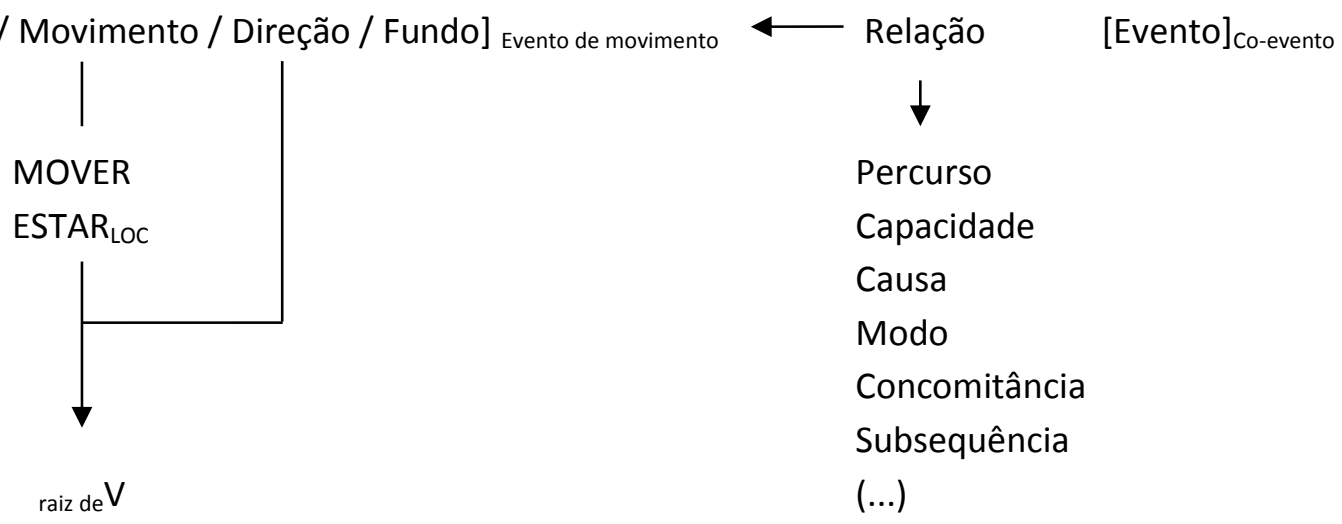

(adaptado de TALMY, 2000, vol.2, p. 49)

Aqui, serão seguidas as ideias de Mateu \& Rigau (1999), que fazem uma proposta de mapeamento sintático do processo de amálgama (conflation) de Talmy (2000). Os autores propõem que as noções do padrão de lexicalização propostas por Talmy (op. cit.) eventos que denotam movimento seriam codificadas de maneira diferente em línguas germânicas e românicas, a extensão do "molde cognitivo" de Talmy (op. cit.) para outros tipos de eventos, conforme pode ser visto em (46)- (47), acima, poderia explicar as relações translinguísticas no que diz respeito à formação de determinadas construções sintáticas. Barbosa (2008), por exemplo, se baseia nessa ideia para mostrar que construções resultativas não ocorrem no PB pelo fato de que as partes do macroevento expressos pelos itens lexicais dessa língua são diferentes de línguas como o inglês, dadas as suas classificações em emoldurações distintas.

Assim sendo, a pergunta que surge é a seguinte: a emolduração das construções em (29) seria diferente da emolduração das construções em (30) (acima)? Se os argumentos a favor da separação entre (29) e (30) apresentados até aqui forem levados em consideração, a resposta é: sim. Afinal, se PB é uma língua emoldurada pelo verbo, construções como (29) não poderiam apresentar uma emolduração diferente daquilo que PB pode codificar por meio de seus itens lexicais quando na descrição de um macroevento, seja qual for. Por outro lado, se as 
construções em (29) caírem sob a classificação de emolduradas pelo verbo, não haveria distinção entre PB e inglês. Por conta deste impasse, é necessário determinar quais são os fatores que permitem determinar a emolduração das construções em (29), de modo a excluílas da emolduração pelos satélites, sem excluí-las de poderem ocorrer em línguas como o inglês.

Lembrando-se das observações sobre os dados que foram classificados como predicados complexos encaixados, feitas na seção 2.1. (acima), é possível notar que (29)a e (29)b são construções "diferentes" do restante de fenômenos considerados como predicados complexos, pelo fato de apresentarem dois VPs encabeçados por núcleos diferentes (make leave, "fazer sair", see leave, "ver sair"), e que, por sua vez, fazem exigências lexicais específicas de argumentos internos e externos para ambos os componentes do predicado complexo em questão, e o verbo da oração matriz seleciona a oração infinitiva como complemento.

Em todos os outros casos, seja de (29) ou de (30), mesmo que o argumento interno da oração única não seja compartilhado pelo predicado complexo, todos são casos de uma única estrutura de predicação (um único VP). Traduzindo este fato para a questão do eventomoldura, em (29)a e (29)b há, de certa maneira, mais de uma corrente Agente-causal, algo ausente em todos os outros predicados complexos. Ou seja: parece que, ao contrário dos outros predicados complexos, construções causativas e perceptuais denotam mais de um macroevento - representados por cada domínio flexional de cada verbo da construção ${ }^{22}$. Mas o macroevento é denotado por uma ou duas sentenças? Ambos, afirma Talmy:

\footnotetext{
${ }^{22}$ Na literatura da Gramática Gerativa, denominam-se esses casos como predicados complexos exatamente pelo fato de que o verbo da oração encaixada, não apresentando flexão, faria parte do domínio flexional do verbo matriz. Mais adiante, a questão do domínio flexional e sua importância para excluir construções causativas do rol de predicados complexos relevantes para o Parâmetro de Composição será abordada.
} 
“... por um lado, o macroevento é expresso por uma única oração e é regularmente conceitualizado como um único evento. Por outro lado, uma análise sintática e semântica mais próxima de tais orações únicas se assemelha de maneira próxima àquela de um evento complexo de uma determinada classe e, de fato, eles podem frequentemente ser expressos alternativamente por sentenças complexas".

(TALMY, 2000, pp. 216-217, tradução minha)

Assim, pode-se dizer que línguas emolduradas pelos satélites são capazes de denotar, por meio de duas sentenças/orações, o mesmo mapeamento que línguas emolduradas pelo verbo fazem em uma sentença/oração simples. Logo, se a expressão de um macroevento é, de fato, flexível, pode-se imaginar que construções causativas e perceptuais, da mesma maneira que construções de línguas emolduradas pelo verbo, não sejam capazes de integrar o eventomoldura e o co-evento, em contraste às construções de línguas emolduradas pelos satélites, em (30). Por isso, a proposta aqui é a de que o mapeamento de macroeventos de pelo menos (29)a (causativas) e (29)b (perceptuais), em qualquer das emoldurações que uma língua possa ter, seja compatível com $(48)^{23}$ :

\footnotetext{
${ }^{23}$ É importante notar que o mapeamento sintático do macroevento em línguas emolduradas pelo verbo coincide com o mapeamento de qualquer expressão sintática que apresente duas orações, mas, em línguas emolduradas pelos satélites (e.g., inglês), não ocorre em contextos em que o mapeamento prototípico realiza dois eventos em uma única oração.
} 

emolduradas pelos satélites sobre os predicados complexos encaixados

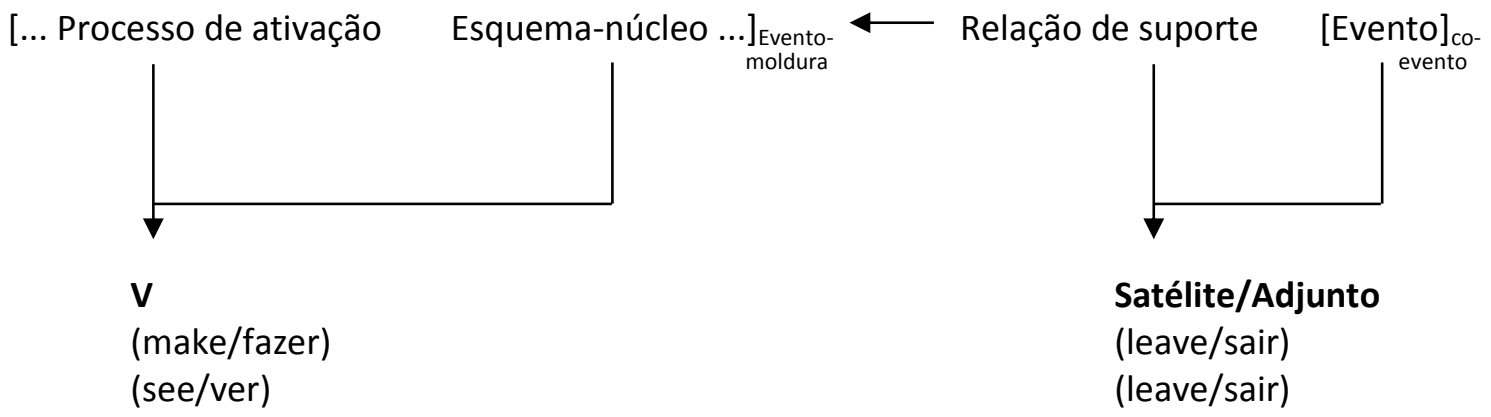

(adaptado de TALMY, 2000, vol.2, p. 223)

Já os predicados complexos presentes em sentenças como (30), que só ocorrem em línguas emolduradas pelos satélites, seriam casos típicos de integração de evento ${ }^{24}$, e, portanto, compatíveis com o esquema em (49), abaixo:

(49) Aplicação da conversão sintática do mapeamento de macroevento em línguas emolduradas pelos satélites sobre os predicados complexos puros

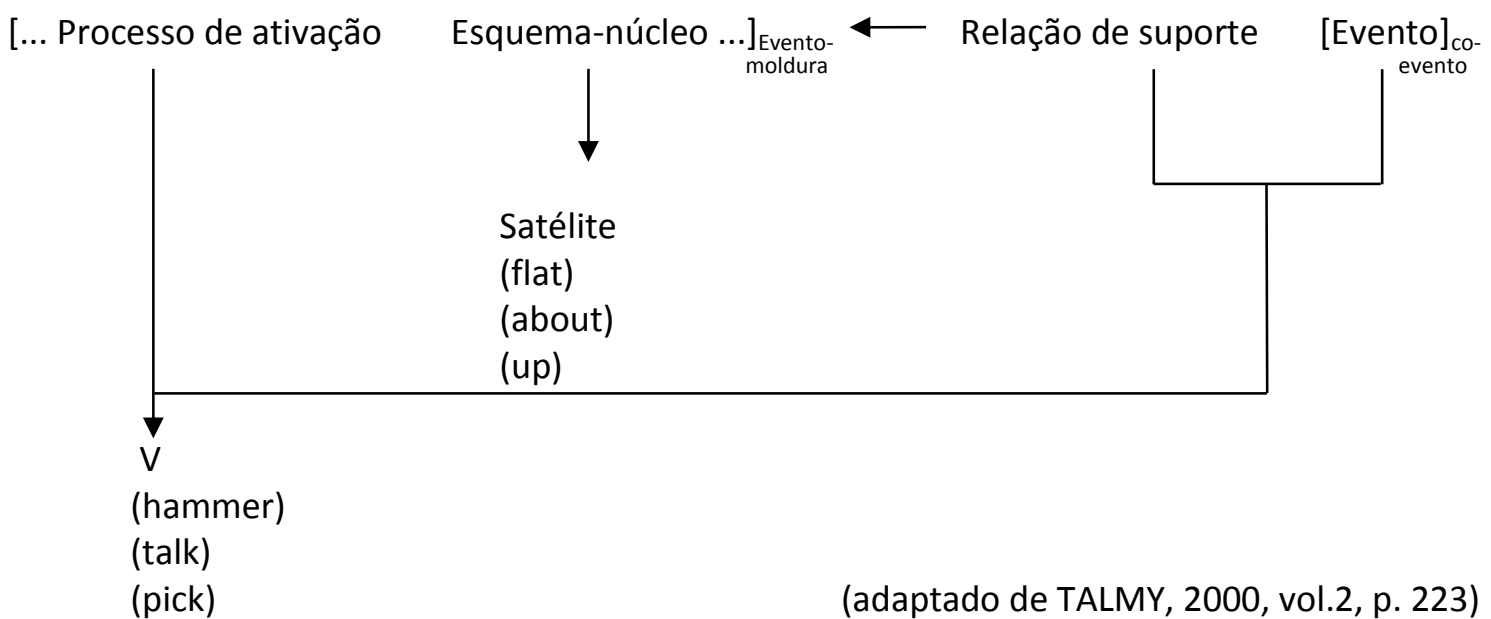

\footnotetext{
${ }^{24}$ Para Talmy (2000), integração de evento é a expressão de um evento complexo (um macroevento) por meio de uma única oração.
} 
Com as definições acima, parece possível excluir predicados encaixados do rol de construções relevantes para o Parâmetro de Composição, ao menos quando colocados em contraste com os predicados complexos "puros" (cf. seção 2.1., acima). Porém, ainda é necessário efetuar uma distinção entre os predicados complexos puros e os predicados pseudocomplexos. Ao invés de dizer que esses predicados complexos sejam formados pela união do verbo e seu argumento interno indireto, será proposto que os objetos direto e indireto sejam selecionados pelo verbo numa espécie de mini oração, formada por uma projeção funcional. Dessa forma, a isometria entre relações semânticas e sintáticas se mantém, e o mapeamento visto em (49) se justifica. Para justificar essa escolha - aparentemente arbitrária nesse primeiro momento - uma discussão dessas construções será feita mais adiante, no capítulo 4. Adotando a proposta em questão, o esquema para os predicados pseudo-complexos se dá como pode ser visto em (50), abaixo:

(50) Aplicação da conversão sintática do mapeamento de macroevento em línguas emolduradas pelos satélites sobre os predicados pseudo-complexos

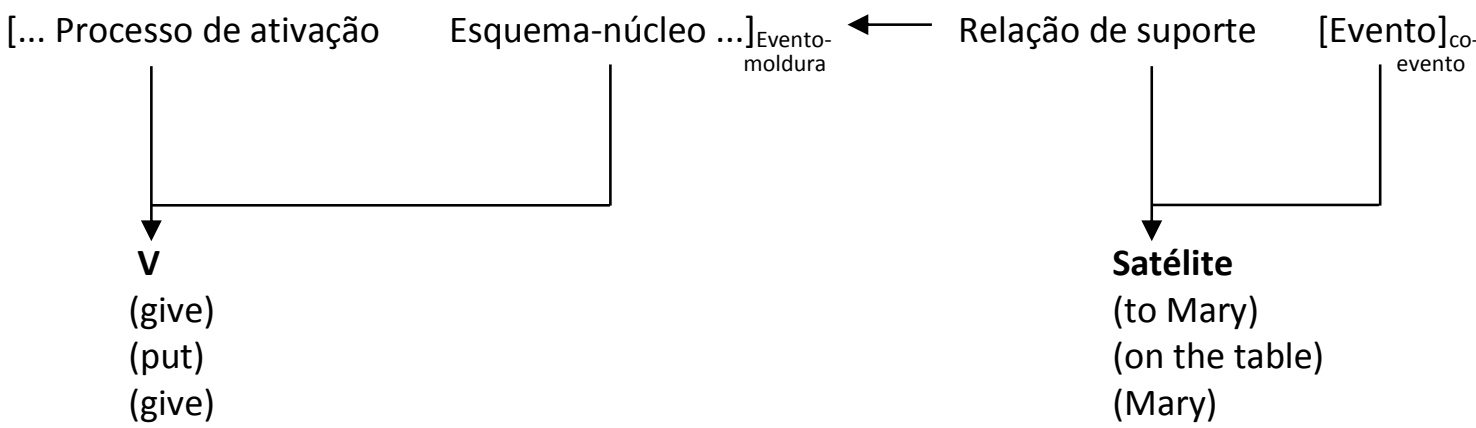

(adaptado de TALMY, 2000, vol.2, p. 223) 
A discussão sobre os predicados pseudo-complexos e sua relação com os predicados complexos puros, bem como a definição de sua importância para a nova definição do Parâmetro de Composição serão feitas mais adiante, nos capítulos 4 e 5 . Na próxima seção, serão apontados argumentos empíricos que permitem excluir definitivamente as construções causativas (e, consequentemente, construções perceptuais) do rol de sentenças relevantes para o Parâmetro de Composição, além de mostrar uma proposta preliminar de estrutura sintática que separe os predicados de acordo com as observações feitas na seção 2.1. (acima) para predicados complexos puros, pseudo-complexos, e encaixados.

\subsection{Questões teorico-conceituais}

Nesta seção, serão apontadas as questões teóricas que são problemáticas quando se tenta aplicar o Parâmetro de Composição (SNYDER, 1995) dentro de análises sintáticas mais refinadas. O trabalho de Snyder lida primeiramente com aquisição de linguagem - e, por conta disso, se preocupa mais com questões empíricas da aquisição em si, ao invés de explicar a estrutura sintática dos fenômenos de maneira detalhada - e, por conta disso, deixa algumas definições de lado, que, de acordo com o que será demonstrado ao longo desta tese, são de importância crucial para que a questão do Parâmetro de Composição se adeque aos desafios que os dados do PB apresentam. A questão mais importante, porém é a definição do termo "predicado complexo". Na próxima seção, serão discutidos alguns pontos de vista na literatura, e será dada uma definição mais sólida, compatível com a proposta da seção 2.2.1. (acima) 


\subsubsection{O que são predicados complexos?}

Sempre que se tenta definir um termo técnico em Gramática Gerativa - ou em qualquer disciplina científica que seja - é bem provável que, após algum tempo, a verdadeira acepção do termo já tenha se perdido, ou que várias definições paralelas tenham surgido, utilizando-se da mesma denotação terminológica (cf. BARBOSA, 2008, acerca das definições do termo construção). O caso do termo predicado complexo, não é uma exceção. Baker (1996) já apontara o fato por meio da seguinte afirmação:

“O termo 'predicado complexo' não apresenta significado preciso na teoria atual; ele pode referir-se a qualquer predicado ao qual um dado pesquisador atribui uma representação com estrutura interna em algum nível."

(BAKER, 1996, p. 338, tradução minha)

Tendo consciência do problema em mãos, o objetivo desta seção não é dizer qual a origem do termo, nem discutir qual a versão correta; afinal, as ciências em geral precisam de metalinguagem para descrever os fenômenos que elas se propõem a investigar. Porém, explicitar qual a acepção do termo predicado complexo que será levada em conta nesta tese se faz necessário, de maneira que seja possível entender os questionamentos que serão feitos sobre a proposta de Snyder (1995) descrita acima, especialmente no que diz respeito às construções agrupadas pelo autor e aos fatos empíricos observados no PB. 
Gonçalves (1999), tomando por base os trabalhos de Williams (1997) e Baker (1996), aponta uma distinção na literatura entre predicados complexos lexicais e predicados complexos sintáticos. Williams (1997, apud GONÇALVES, 1999) faz uma distinção entre construções resultativas (51) e construções de mini oração com verbos do tipo de considerar (52):

(51) John wiped the table clean.

(52) John considers the table clean.

(WILLIAMS, 1997, p. 13, apud GONÇALVES, 1999, p. 39)

De acordo com Gonçalves (op. cit.), Williams (apud GONÇALVES, idem) aponta existir uma diferença de comportamento sintático nestes verbos, apesar de suas formas superficiais idênticas (cf. (53), (54), abaixo):

(53) John wiped clean the table.

(54) *John considers clean the table ${ }^{25}$.

(WILLIAMS, 1997, p. 13, apud GONÇALVES, 1999, p. 39)

${ }^{25}$ Williams (apud GONÇALVES, op. cit.) aponta para o fato de que, em casos de heavy NP shift, a ordem V-predicado-NP é obrigatória:

(i) John considers clean any table with a reflectant surface. 'John considera limpa qualquer mesa com uma superfície brilhante.'

(WILLIAMS, 1997, p. 13, apud GONÇALVES ,1999, p. 39) 
Por conta dessa assimetria, Williams propõe que predicados complexos como (51) sejam formados por meio de uma regra lexical - daí serem chamados predicados complexos lexicais - e seriam os únicos predicados complexos "verdadeiros". Já predicados como (52) não seriam produto de tal regra, assim como construções causativas "faire à dativo" do Francês (55):

(55) Jean fait manger la pomme à Marie.

(WILLIAMS, 1997, p. 13, apud GONÇALVES, 1999, p. 40)

Baker (apud GONÇALVES, 1999), por sua vez, se vale da mesma distinção para ressaltar outra assimetria. O autor argumenta que o fenômeno de incorporação do nome ao verbo em línguas polissintéticas seja fruto de operações de movimento sintático. Desse modo, formas nominais em línguas polissintéticas como as de tiwa do sul (cf. (56), (57), abaixo), por serem incorporadas ao verbo, compõem uma forma verbal que é complexa morfologicamente, carregando marcas de concordância e tempo que associam essas formas nominais ao argumento interno do verbo.

(56) Seuan-ide ti-mu-ban.
Homem-SUF 1sS/AO-ver-PAST ${ }^{26}$
'Eu vi um/o homem.'

(ALLEN; GARDINER; FRANTZ, 1984, apud GONÇALVES, 1999, p. 40)

\footnotetext{
${ }^{26}$ Lista de abreviaturas (apud GONÇALVES, 1999, p. 40, nota 6):

SUF - sufixo flexional nominal

$1 \mathrm{sS}-1^{\mathrm{a}}$ pessoa singular Sujeito

AO - concordância da classe do nome
} 
(57)

Ti-seuan-um-ban.

1sS/AO-homem-ver-PAST

'Eu vi um/o homem.'

(ALLEN; GARDINER; FRANTZ, 1984, apud GONÇALVES, 1999, p. 40)

Em contrapartida, nomes compostos do tipo $\mathrm{V}+\mathrm{N}$ do inglês seriam formados por meio de regras lexicais, já que podem ser usados como verbos (58), não podem ser usados de maneira separada (59), e apresentam diferenças de valor referencial (60); enquanto nos dados de tiwa do sul (cf. (56), (57), acima) os argumentos internos do verbo só possuem uma leitura referencial específica, os complementos de compostos do inglês só podem ser interpretados de maneira genérica. Assim, (60)c não poderia ser a continuação natural de (60)a, mas de (60)b:

(58)

a.I baby-sat for the DeOrios last week.

Eu bebê-sentei para os DeOrios última semana

'Eu trabalhei como babá para os DeOrios na semana passada.'

b. We need

to grocery-shop

tomorrow.

Nós precisar

para mantimentos-comprar

amanhã

'Nós precisamos comprar mantimentos amanhã.'

c. Kevin bar-tends on Friday night.

Kevin bar-atende na sexta-feira noite

'Kevin trabalha de garçom na sexta-feira à noite.'

(BAKER, 1988, apud GONÇALVES, 1999, p. 41; glosa e tradução minhas) 
(59) a. *I sat the baby for the DeOrios last week.

b. *We need to shop the groceries tomorrow.

c. ${ }^{*}$ Kevin tends the bar on Friday night.

(BAKER, 1988, apud GONÇALVES, 1999, p. 41)

(60) a. John is a truck driver.

'John é um motorista de caminhão.'

b. John drives a truck for a living.

'John dirige um caminhão para se sustentar.'

c. It is parked over there behind the gas station.

'Ele está estacionado ali atrás do posto de gasolina.'

(BAKER, 1988, apud GONÇALVES, 1999, p. 41; glosa e tradução minhas)

Pelo que é possível notar com as definições acima, existe uma separação no que diz respeito a dois tipos de predicados complexos: o primeiro deles seria formado no léxico, como produto de operações morfológicas, enquanto o segundo tipo é fruto de operações sintáticas.

Nesta seção, é possível ver que o que pode ser chamado de "predicado complexo" é, de fato, abrangente, mas pode ser dividido de maneira mais uniforme do que inicialmente era imaginado, tendo em vista a citação de Baker (1996) no início da seção (acima). Ainda assim, resta uma questão: quais dos predicados complexos discutidos na seção 2.1.1. são relevantes para a variação paramétrica, e, consequentemente, para a discussão do Parâmetro de Composição?

Costuma-se dizer que o léxico é "o lugar onde se encontram as idiossincrasias". De acordo com o que foi visto acima, processos morfológicos tendem a lidar com uma complexidade semântica maior nos elementos que compõem um predicado complexo lexical. 
Por apresentar tantas propriedades peculiares, e que variam de língua para língua, seria plausível afirmar que os predicados complexos lexicais, em oposição aos predicados complexos sintáticos, são um tipo de predicado complexo mais sujeito à variação paramétrica, dadas as suas maiores peculiaridades. Sem contar que os dados de predicados complexos sintáticos estão presentes em PB, conforme mostrado nas seções 2.1.2.1. e 2.1.2.2., o que inviabilizaria uma análise paramétrica incluindo tais predicados.

Conforme já foi dito, variações paramétricas de nível lexical são objeto de estudo das teorias de análise microparamétrica, que acreditam que apenas as projeções funcionais desses itens contribuem para a variação entre as línguas. Nesse caso, os predicados complexos lexicais apresentam um desafio para as propostas microparamétricas. Como explicar a variação entre as línguas a partir de projeções funcionais?

Esse tipo de comparação parece razoável se levarmos em conta o panorama das teorias que lidam com variação paramétrica mencionadas na seção anterior. Conforme foi visto, as propostas microparamétricas apostam no léxico como o grande responsável pela variação. Desse modo, poderia ser dito que os predicados complexos em questão para variação paramétrica seriam apenas os predicados complexos lexicais. Por outro lado, as propriedades de predicados complexos citadas acima comparam línguas de famílias de relação relativamente distante, uma característica mais próxima do escopo de análises macroparamétricas.

Levando em conta os pontos de vista teóricos sobre variação paramétrica e a classificação de predicados complexos proposta acima, acredita-se que, mantendo as definições de léxico e de variação tal como elas se apresentam, é gerado um paradoxo do qual só é possível escapar caso seja adotada uma nova perspectiva teórica - seja sobre variação paramétrica, seja sobre a noção de léxico. Por mera escolha metodológica, a questão que se 
acredita ser necessário mudar é a da distinção entre formação de predicados complexos sintáticos e predicados complexos lexicais.

A maneira como o léxico deve ser visto dentro de um modelo de representação da faculdade da linguagem é motivo de grande debate na literatura gerativista atual. Seria o léxico um componente da gramática responsável por formar palavras - e, mais importante, formar predicados complexos? A resposta que este trabalho adota para essa questão é não!

Para motivar tal ponto de vista, será utilizado o arcabouço teórico da Morfologia Distribuída (HALLE; MARANTZ, 1993), o qual será explicitado nos pontos relevantes para a compreensão da proposta adotada mais adiante para desenvolver a hipótese de trabalho.

\subsubsection{Morfologia Distribuída: um breve panorama}

Quando se fala de léxico dentro da Gramática Gerativa, o que a maioria dos teóricos assume é a visão clássica de o léxico ser um conjunto de itens, formados sob certas regras e condições de formação autorreguladas. A partir dessa definição, a estrutura que se utiliza em teorias sintáticas lexicalistas (e.g., o Minimalismo) para representar o léxico e seu papel na derivação sintática é a seguinte: 
(61) Exemplo de modelo de arquitetura da Faculdade da Linguagem lexicalista:

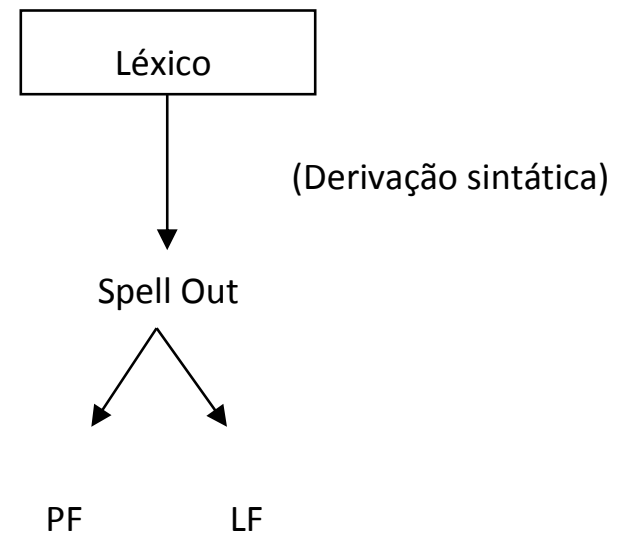

Num esquema como o mostrado acima, o léxico é o ponto de partida para a derivação. Dele, são retirados todos os elementos que vão ocupar os nós terminais da estrutura sintática, e antes da chegada à parte correspondente à realização fonológica da sentença, há a passagem por um componente morfológico, que é responsável pelos processos de reestruturação dos itens lexicais (como alomorfia, por exemplo).

Segundo Marantz (1997), a hipótese lexicalista defende uma proposta ainda mais abrangente para a noção de léxico do que a do esquema acima, que é utilizada pela maioria dos teóricos em Gramática Gerativa. Para o autor, esta hipótese considera que o léxico funciona como um local de armazenamento de itens lexicais prontos, que são retirados para a formação de sentenças. O léxico também manipula palavras com estrutura interna complexa, não apenas itens lexicais formados por elementos fundamentais ou indivisíveis. Nessa teoria as palavras são criadas diretamente no léxico, e tais processos diferem dos processos de formação de sentenças. 
O lexicalismo assume ser possível que, dentro do componente lexical exista tanto uma lista de conexões de som e significado para a criação dos morfemas ${ }^{27}$, quanto os itens que trazem informações idiossincráticas sobre essas conexões. Ou seja, o componente lexical e a sintaxe funcionariam de forma semelhante, relacionando som ao significado nos limites da palavra e nos limites da sentença, respectivamente. O principal argumento dos lexicalistas, segundo Marantz, é que "nós sabemos coisas sobre palavras que não sabemos sobre sintagmas e sentenças" ${ }^{28}$. Marantz é contra esse argumento, dizendo que vários domínios, como o de regras léxico-fonológicas e de aparente correspondência entre estruturas/significados especiais, por exemplo, não coincidem na palavra e que, de fato, esses domínios não se correlacionam um com o outro. Portanto, esse tipo de representação para o léxico seria redundante, já que ele operaria analogamente à sintaxe, além de ser muito abrangente, já que nem todas as regras de correspondência lexical parecem ser aplicadas no léxico.

Embick \& Noyer (2004) afirmam que, pela proposta da Morfologia Distribuída, as palavras seriam montadas pela sintaxe, ou seja, as palavras não são um objeto derivacional privilegiado, quando se considera que todos os objetos complexos (palavras e sentenças) são produzidos por meio de um mesmo sistema gerativo (nesse caso, a sintaxe). Além desses pressupostos iniciais, os autores apoiam-se no quadro do Programa Minimalista de Chomsky (1995), e a partir dele, reafirmam ser improvável a existência de um léxico gerativo, já que Chomsky diz que a gramática deve essencialmente conter:

\footnotetext{
${ }^{27}$ Cabe ressaltar que Marantz (1997) distingue a definição de morfema utilizada pelos lexicalistas em oposição à noção de morfemas da teoria da Morfologia Distribuída, cuja definição se encontra no decorrer do texto.

${ }^{28}$ Marantz, 1997, p. 202 (tradução minha).
} 
- Um conjunto de primitivos;

- Um sistema derivacional que combine esses primitivos em (uma quantidade infinita de) objetos complexos;

- Uma interface com o sistema conceitual/intencional (LF);

- Uma interface com o sistema articulatório/perceptual (PF).

Marantz (op. cit.) acredita ser necessário supor a existência de uma lista (ou mais) de elementos primitivos; listas que o sistema computacional precisa manipular para transformar esses elementos primitivos em unidades maiores de significação. Além disso, essas listas devem ser acessadas em diferentes níveis através do curso da derivação sintática.

As palavras, resultado da derivação e da atuação de três listas (cf. (62), abaixo) durante a derivação, são assumidas como sendo formadas por operações sintáticas (merge e move). Em acréscimo ao sistema descrito acima, haveria um componente morfológico atuando após o spell-out. Além desse componente, alguns processos em PF poderiam modificar e elaborar a estrutura sintática de forma limitada. Essas modificações fariam parte do sistema e ocorreriam excepcionalmente para a "correção" da fonologia. Porém, os autores afirmam que no caso default, a estrutura morfológica em PF é simplesmente a estrutura sintática, ou seja, os processos de modificação não são obrigatórios. Esses processos poderiam ocorrer tanto na sintaxe propriamente dita quanto em PF.

A estrutura de um componente de listas, que, eventualmente substituiriam o léxico numa estrutura sintática derivacional é representada por Embick \& Noyer (2004) pelo seguinte esquema: 
(62)

The Grammar, with Lists

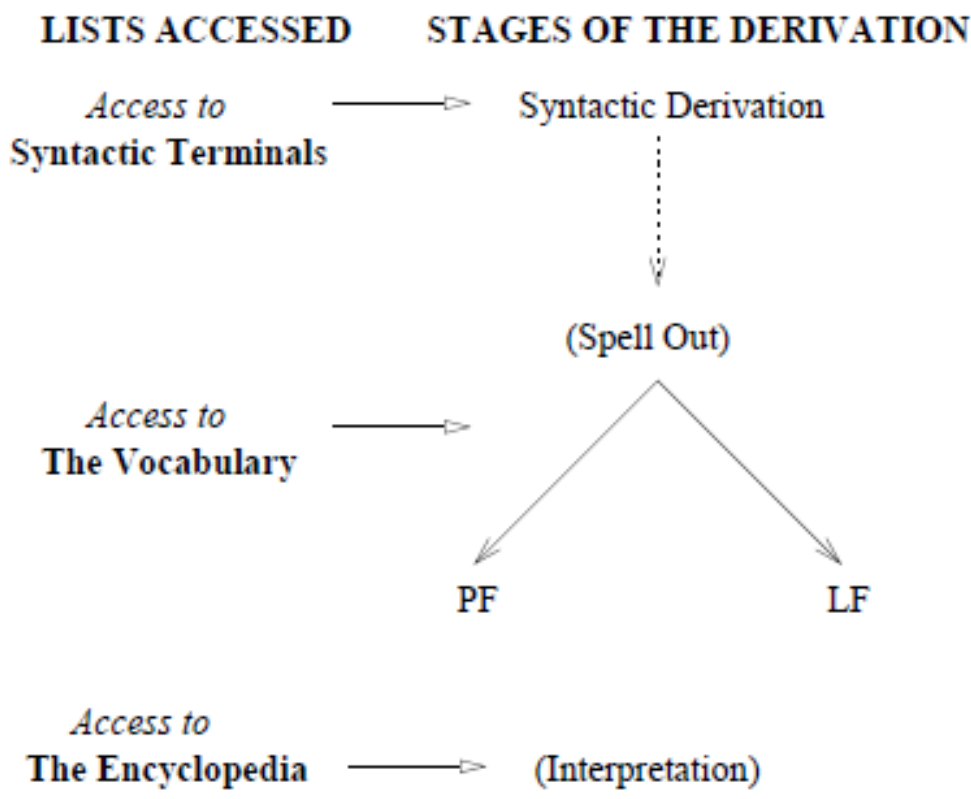

(Embick \& Noyer 2004; p. 9)

Nessa redefinição do componente lexical e suas funções na derivação da estrutura sintática, Embick \& Noyer definem as listas do 'léxico' da seguinte maneira:

\section{(i) Traços morfossintáticos}

Formam uma lista de elementos primitivos, que ocupa o lugar antes creditado ao léxico de outras teorias. Ela é composta por raízes (elementos mínimos de significação) e por elementos primitivos ausentes de conteúdo fonológico (como traços de gênero, pessoa, tempo, entre outros), que formam os morfemas abstratos. Raízes incluem o conjunto de traços fonológicos juntamente com, em alguns casos, traços diacríticos não fonológicos. Como exemplos de raízes, temos, no PB, $\sqrt{ }$ gat-, $\sqrt{ }$ dorm-, ou $\sqrt{ }$ dia. De uma maneira bastante ampla, o 
conceito de raiz pode ser diretamente relacionado com o signo Saussureano, no que diz respeito à indivisibilidade entre significante e significado ${ }^{29}$.

(ii) Itens de Vocabulário

Itens de vocabulário são expressões fonológicas inseridas nos nódulos terminais da sintaxe que possuem um conjunto de morfemas abstratos compatíveis com seu contexto de possível inserção. Apesar da necessidade de inserção de um item de vocabulário que seja compatível com seus traços, um morfema abstrato não necessariamente exige que o item de vocabulário que o preencha seja completamente compatível com seus traços.

Segundo o Princípio do Subconjunto, um item de vocabulário pode ocupar uma posição se 0 item possui todos ou um subconjunto dos traços especificados para aquela posição. 0 item de vocabulário, porém, nunca deve conter algum traço que não esteja presente no morfema abstrato para que possa ser licenciado em um nódulo. No caso de mais de um morfema capaz de preencher esses pré-requisitos, aquele que possuir maior número de traços ocupa o nódulo terminal do morfema abstrato. Um exemplo de item de vocabulário: a expressão regular de plural no português, cuja representação dentro do modelo se dá pela seguinte maneira:

$$
/ s / \leftrightarrow \text { [plural] }
$$

Quando essa regra se aplica ao morfema [plural], o efeito resultante é o de acréscimo desse elemento fonológico àquele nódulo. Mas no português essa não é a única forma de realização para o plural. Há também casos com o de mulheres, e lápis. Nesses casos, há uma

\footnotetext{
${ }^{29}$ Há, dentro da teoria, um debate sobre a presença de conteúdo fonológico na raiz, ou se este é inserido após a derivação sintática. Porém, essa distinção não será relevante para a discussão deste trabalho.
} 
condição adicional de restrição fonológica, e a realização da vogal adicional em mulheres ou da assimilação do segundo /-s/ em lápis ocorrem por meio de reajustes em PF.

(iii) A Enciclopédia: o diálogo com o conhecimento extralinguístico

A Enciclopédia é definida pelos autores como um conjunto de informações semânticas que devem ser listadas como propriedades de uma determinada raiz, obtendo essas propriedades seja pelo conhecimento de mundo, seja pelas interpretações derivadas de um objeto mais complexo construído sintaticamente (expressões idiomáticas como chutar o pau da barraca). Essa lista abrigaria conotações para certas palavras tais como âncora, que tem propriedades polissêmicas, fazendo com que a interpretação dada pelo sistema seja feita de acordo com o contexto de utilização da expressão. No caso de elementos que possivelmente se encontravam nessa relação, e por algum motivo perderam esse núcleo semântico comum através dos tempos - como vela, por exemplo - o componente faz com que se adquira uma nova raiz no conjunto de elementos primitivos, com um mesmo conteúdo fonológico, diferenciadas apenas pelos traços formais nelas contidos.

Nesta seção, foram descritos brevemente os mecanismos com os quais a Morfologia Distribuída trabalha, e mencionadas algumas das propriedades que serão levadas em conta ao longo do desenvolvimento do trabalho. O fator mais importante a ser notado é a ausência de distinção entre o local em que são geradas expressões nominais - os nomes compostos sendo os casos relevantes nesta tese - e as expressões sintáticas, como os predicados complexos. Com o aparato técnico oriundo dessa teoria, será possível integrar as correntes teóricas da semântica cognitiva e da gramatica gerativa, bem como suscitar um importante debate acerca das distinções entre variação micro- e macroparamétrica para a formação de nomes compostos e predicados complexos. 


\subsection{Conclusão}

Neste capítulo, foi discutida a questão do Parâmetro de Composição (SNYDER, 1995, 2001) e os problemas que este apresenta quando são levados em conta os dados do PB, bem como uma apresentação dos modelos teóricos que servirão de base para a análise dos dados do PB na proposta de reformulação do Parâmetro de Composição. O próximo capítulo desta tese tratará dos nomes compostos com base na Morfologia Distribuída, explicando a ausência de produtividade de compostos $\mathrm{N}+\mathrm{N}$ no $\mathrm{PB}$, bem como a busca de uma explicação para os compostos do tipo $\mathrm{N}+$ de $+\mathrm{N}$ nessa língua, e suas propriedades de composto "tradicional". 


\title{
Capítulo 3
}

\section{O Parâmetro da Realização Fonológica de}

\author{
Núcleos: reanalisando a estrutura de
}

\section{expressões nominais}

Neste capítulo, serão introduzidos argumentos em favor de uma análise estrutural para os nomes compostos do inglês por meio de uma estrutura sintática compatível com os compostos $\mathrm{N}+$ de $+\mathrm{N}$ em $\mathrm{PB}$, e será proposto que a variação paramétrica entre as formas de superfície das construções do PB e do inglês se dá no caminho para PF, e não no componente computacional. Antes disso, é importante explicar a motivação para tal análise.

Conforme mencionado na seção 2.1 (acima), o trabalho de Snyder $(1995,2001)$ traz um problema quando se observam os dados do PB. Por abranger um grande número de construções, a hipótese de Snyder acaba enfraquecida. Afinal, conforme foi mostrado no capítulo 2, o conjunto de construções sintáticas evocado por Sugisaki \& Snyder (2002) não confirma suas previsões quando o PB é observado. Considerando que essa língua não é marcada positivamente para o Parâmetro de Composição, ela não deveria possuir qualquer tipo de predicado complexo. Por conta disso, foi feita uma classificação das características sintáticas e semânticas das construções apontadas por Sugisaki \& Snyder (2002), e foi visto 
que - com exceção da construção de objeto duplo ${ }^{30}$ - as únicas construções impossíveis em PB são aquelas cujo esquema de emolduração é impossível em uma língua como o PB.

Por conta desse problema, foi proposta uma definição mais restrita da noção de predicado complexo, de modo a ser possível delimitar o escopo do Parâmetro formulado por Snyder. Com essa definição mais restrita, foi possível determinar propriedades semânticas que separassem as construções que ocorrem em PB, mas não deveriam, se o Parâmetro de Composição estiver correto.

Da mesma forma, mas em sentido oposto, este capítulo tem a intenção de fornecer uma definição mais ampla - ao invés de mais restrita - para o processo de composição. Com base em argumentos de ordem semântica, será mostrado que tanto compostos $\mathrm{N}+\mathrm{N}$ (forma nominal complexa mais produtiva do inglês) quanto compostos $\mathrm{N}+d e+\mathrm{N}$ (forma nominal complexa mais produtiva do PB) apresentam as mesmas propriedades semânticas (de interpretação) entre si.

Com base nessas semelhanças semânticas, será proposto que, apesar de apresentar propriedades de construções superficialmente distintas, o composto $\mathrm{N}+d e+\mathrm{N}$ seja, em $\mathrm{LF}$, estruturalmente idêntico ao composto $\mathrm{N}+\mathrm{N}$ do inglês. A hipótese defendida é a de que ambos os compostos sejam formados na sintaxe e compartilhem a mesma projeção funcional, em uma relação semântica baseada em operadores que nucleiam e determinam as propriedades da relação entre os membros do composto (cf. DI SCIULLO, 2005). Suas diferenças se dão apenas por conta de operações realizadas no componente morfológico, com base na variação paramétrica de realização fonológica de núcleos da projeção funcional que gera tanto os compostos do inglês quanto os compostos do PB.

\footnotetext{
${ }^{30}$ A ausência de construções de objeto duplo, apesar de serem enquadradas como estruturas de línguas emolduradas pelo verbo no capítulo 2 , será explicada mais adiante, no capítulo 4.
} 
Antes de apresentar os argumentos e definir a análise para os nomes compostos, é necessário definir as noções clássicas acerca do tema na literatura, bem como a definição de composição e composto a ser utilizada aqui, de modo a relacionar a análise aqui apresentada ao Parâmetro de Composição. Essa definição é feita abaixo.

\subsection{Processos de Formação de Palavras}

3.1.1. Bases, raízes, afixos, derivação e composição: a formação de palavras no inglês

Numa descrição dos processos de formação de palavras do inglês, Plag (2003) observa que existe uma distinção entre palavras como as em (63)a e (63)b quando comparadas com as palavras em (63)c. Por serem compostas por elementos menores que formam palavras de significado mais complexo, as palavras em (63)a e (63)b são chamadas de palavras morfologicamente complexas.

(63) a. employee

inventor

inability

meaningless

suddenness

unhappy

decolonialization b. apartment building

greenhouse

team manager

truck driver

blackboard

son-in-law

pickpocket c. chair

neighbor

matter

brow

great

promise

discuss 
Uma palavra como neighbor (vizinho) é considerada uma palavra simples porque não pode ser dividida em neighb- e -or, por exemplo, apesar de -or ser um morfema visível em outras palavras, como em inventor (invent- + -or). Já a palavra decolonialization (descolonialização), por sua vez, pode ser decomposta em de-, colony, -al, -ize, e -ation. Dentro desta palavra, é possível ainda perceber que existem morfemas dependentes, como -al, e morfemas independentes, como colony (colônia).

O morfema -al é chamado de afixo, pois precisa estar preso a um outro morfema para ser realizado na língua. Já os morfemas que são independentes são chamados de bases, como colony, por exemplo. Colony também é, por sua vez, uma raiz, pois não pode ser decomposta em qualquer outro morfema visível.

Qualquer palavra formada a partir de uma base (como colony, por exemplo) é uma palavra derivada. Assim, derivação é um dos processos de formação de palavra do inglês. Outro tipo de formação de palavras se dá através da combinação de duas raízes; este processo é chamado de composição, e produtos desse processo de formação de palavras podem ser vistos em (63)b, acima. Existem, ainda, outros tipos de formação de palavras citadas por Plag, como conversão, truncamento e blendinq, que não serão discutidos aqui, já que o objetivo deste capítulo é observar a formação de compostos.

Na próxima seção serão mostradas as definições sobre os processos de formação de palavras em PB, com ênfase no processo de composição, suas propriedades semânticas e seus tipos de formação sintática. A partir dessas definições, será feito um contraste com as propriedades de nomes compostos do inglês, e uma definição para o processo de composição será proposta, de modo a explicar as relações paramétricas propostas pelo Parâmetro de Composição (SNYDER, 1995). 
3.1.2. A formação de palavras no PB: contrastes entre derivação e composição (Basílio 1987)

Assim como no trabalho de Plag (2003) para o inglês, Basílio (1987) também aponta derivação e composição como os processos mais comuns para formação de palavras no PB.

Palavras derivadas são aquelas unidas a partir de uma base e um afixo, tal como retratista (retrato + -ista), livreiro (livro + -eiro), lavável (lava + -vel), contemplação (contempla +-ação), reler (re- + ler), e predispor (pré- + dispor) (BASíLIO, 1987, p. 27). A autora mostra que existem dois tipos de bases: bases livres - palavras que podem ser utilizadas em qualquer sentença sem acréscimo de qualquer afixo - e bases presas, que são dependentes de um afixo para realização, como psicolog-, que por si só não é uma palavra, mas com o acréscimo de um sufixo como -ico, se transforma na palavra psicológico.

Já a composição tem como produto palavras que são a junção de duas bases, como guarda-chuva (guarda + chuva), luso-brasileiro (luso + brasileiro), sociolinguístico (sócio + linguístico) e agricultura (agri- + cultura) (BASíLIO, 1987, p. 28). Nomes compostos podem ser formados tanto com bases presas como agri-, quanto por bases livres.

Para a autora, a diferença entre a derivação e a composição se dá pelo fato de que cada uma delas satisfaz uma necessidade particular de comunicação. Enquanto a derivação dá conta da expressão de categorias nocionais - nomes de interpretação/significação "simples" -, a composição expressa combinações particulares, ou seja, significados idiossincráticos.

Na derivação, os afixos são delimitadores das funções da palavra a qual se unem, e possuem determinados graus de generalidade. Quanto maior o grau de generalidade, maior a sua produtividade. A autora ainda ressalta que a produtividade não tem relação com a 
alteração da categoria gramatical do elemento que recebe o afixo (e.g., a alta produtividade do prefixo de negação des- e do sufixo -ista, e a baixa produtividade do sufixo que forma adjetivos -udo). Quanto mais produtivo um afixo na língua, mais abrangente a sua interpretação se torna.

Na composição, não existe um elemento fixo, do qual o significado necessariamente deriva, e, consequentemente, "não há uma função predeterminada no nível dos elementos" (BASÍLIO, 1987, p. 30). A estrutura é a responsável por dar o papel dos elementos envolvidos no composto. Quando o composto é do tipo substantivo+substantivo, o segundo nome do composto modifica ou especifica o primeiro (e.g., sofá-cama, peixe-espada, couve-flor); se o composto é do tipo substantivo + adjetivo, o adjetivo é o modificador, não importando a ordem (e.g., obra-prima, livre-arbítrio, caixa-alta, belas-artes); já quando o composto é formado de verbo + substantivo, a relação do substantivo é de objeto do verbo (e.g., guardaroupa, mata-mosquito, porta-bandeira). Assim, a autora conclui que composição é "um processo de formação de palavras que utiliza estruturas sintáticas para fins lexicais" (BASíLIO, 1987, p. 31).

Um contraste interessante é feito pela autora no que diz respeito à diferença entre derivação e composição: a derivação gera "expressões comuns e gerais" (BASíLIO, 1987, p. 31), enquanto a composição "vai permitir categorizações cada vez mais particulares" (idem). Ou seja, para a autora, compostos tendem a se distanciar do significado original de suas partes, pois o composto é a "junção de dois elementos semânticos, de existência independente no léxico, em apenas um elemento lexical” (BASíLIO, 1987, p. 31). 


\subsubsection{Kehdi (1992): Propriedades sintáticas dos compostos do PB}

Kehdi (1992) - em concordância com Basílio (1987) - afirma que derivação e composição são os dois processos mais relevantes para formação de palavras no PB. O autor também diz que compostos são produtos da união de dois vocábulos, resultando em um terceiro, de significação distinta dos elementos iniciais, mesmo que exista alguma relação de significado entre os elementos que formam o composto, como no caso de quebra-nozes, que não pode significar um objeto qualquer que seja utilizado para quebrar nozes.

Para Kehdi, existem dois tipos de formação de compostos: (i) justaposição - quando os elementos continuam como itens individuais (e.g., passatempo, sempre-viva) e (ii) aglutinação - quando existe alteração no acento e na fonologia de um dos termos (e.g., boquiaberto, pernalta). Dependendo do grau de fusão, porém, a palavra deve ser considerada um item simples, como "fidalgo, proveniente de filho dalgo (de filho + de + algo $>$ filho dalgo $>$ fi-dalgo > fidalgo)" (KEHDI, 1992, p. 37); daí a formação de itens como fidalguia, produto da análise de fidalgo como item primitivo.

Por conta dos problemas de classificação em torno da ortografia (hifenização), o autor propõe que a classificação dos compostos seja feita a partir de "critérios linguístico-formais". Kehdi aponta, então, quatro propriedades dos nomes compostos: 
(64) Propriedades dos nomes compostos em PB:

(i) Ordem rígida de sucessão dos termos do composto;

a. amor-perfeito, * perfeito-amor

b. amor-perfeito delicado, * amor delicado perfeito

c. casa de detenção destruída/destruída casa de detenção, *casa destruída de detenção

d. estrada de ferro abandonada/abandonada estrada de ferro, *estrada abandonada de ferro mas,

e. rapaz bom, bom rapaz, rapaz muito bom (adaptado de KEHDI, 1992, p. 40)

(ii) Não é permitido substituir ou suprimir um dos membros do composto;
a. amigo dedicado, amigo fiel
(sintagma livre)
b. amor-perfeito, *amor-imperfeito
(composto)
c. [amor-perfeito], [rosa], [margarida]...
d. colher amores-perfeitos, * colher amores $\emptyset$, ${ }^{*}$ colher $\varnothing$ perfeitos ${ }^{31}$

(adaptado de KEHDI, 1992, p. 41)

\footnotetext{
31 Kehdi atenta para o fato de que há contraexemplos em alguns casos de compostos determinado/determinantes, como carta circular > circular e cidade capital > capital, em que, geralmente, o determinado é apagado, mas a significação geral do composto é mantida.
} 
(iii) Compostos são construções paralelas às suas contrapartes sintáticas;

a. mestre de escola $>$ mestre-escola

b. surdo e mudo > surdo-mudo

c. ganha e perde > ganha-perde

(adaptado de KEHDI, 1992, p. 41)

(iv) Compostos funcionam sintaticamente como uma única palavra;

a. Admiro a estrada de ferro.

b. Admiro a pista.

(adaptado de KEHDI, 1992, p. 42)

Quanto às propriedades sintáticas dos compostos no PB, Kehdi propõe que existam 11 formas sintáticas distintas de compostos, classificadas da seguinte maneira:

(65) Tipos sintáticos de compostos, de acordo com Kehdi (1992):

a. $\mathrm{N}+\mathrm{N}$ :

Determinante + determinado: mãe-pátria / papel-moeda;

Determinado + determinante: peixe-espada / escola-modelo (típico de compostos do PE);

b. $N+P+N$ :

baba-de-moça / pé-de-vento;

c. N+A: (ou vice-versa):

amor-perfeito / belas-artes; 
d. $A+A$ :

surdo-mudo / tragicômico;

e. Pronome $+\mathrm{N}$ :

Nosso Senhor / Vossa Senhoria;

f. Numeral $+\mathrm{N}$ :

três-marias / segunda-feira;

g. $A d v+N / A / V$ :

Benquerença / sempre-viva / bem-querer;

h. $\mathrm{V}+\mathrm{N}$ :

lança-perfume / saca-rolhas;

i. $V+($ conjunção $)+V$ :

corre-corre / leva-e-traz;

j. $\quad V+A d v:$

pisa-mansinho / ganha-pouco;

k. Sintagma:

um Deus-nos-acuda / mais vale um toma que dois te darei.

(adaptado de KEHDI, 1992, pp. 42-43)

Kehdi aponta ainda que, além da modificação, dois tipos de relação podem ser inferidos a partir das formações de compostos acima propostas: (i) concordância/coordenação (itens $a, d$, e i), e (ii) subordinação/complementação (itens $b, h$, e j).

É importante lembrar que o Parâmetro de Composição (SNYDER, 1995, 2001) lida apenas com compostos $\mathrm{N}+\mathrm{N}$ endocêntricos; ou seja, os compostos em (64)c-d e (64)g-k não serão abordados nesta tese. Os casos em (64)e-f serão tratados como expressões cristalizadas a partir de estruturas com determinantes em um DP complexo, que não formam compostos. Os compostos em (64)a-b são os mais importantes a serem considerados, enquanto os 
compostos do mesmo tipo de (64)c serão mencionados mais adiante, mas com pouca influência na estrutura do Parâmetro de Composição (SNYDER, op. cit.) ou na sua reformulação proposta mais adiante.

Pelo que pode ser visto até aqui, os compostos se caracterizam principalmente por (i) serem formados a partir de dois elementos lexicalmente independentes, e (ii) por formarem um significado novo, desassociado dos significados individuais de suas partes. Nas próximas seções, serão observadas propriedades dos compostos do inglês de maneira mais aprofundada. Também será feita uma comparação com o PB, de modo a apontar evidências empíricas para a análise evidenciada em sequência.

\subsubsection{Propriedades gerais dos nomes compostos do inglês}

Esta seção tem como objetivo apontar as propriedades características de nomes compostos, de modo a ressaltá-las para a caracterização da análise sintática que será proposta mais adiante. Os trabalhos de descrição de compostos de Spencer (1991), Bauer (2006) e Olsen (2008) serão observados, e, a partir de uma comparação semântica dos dados do inglês e do $\mathrm{PB}$, será feita uma proposta cujo ponto de vista integra os compostos $\mathrm{N}+d e+\mathrm{N}$ do $\mathrm{PB}$ a um processo sintático mais comum do que o demonstrado na literatura, sem deixar de lado as questões de interface entre a morfologia e a sintaxe que tal afirmação carrega consigo. 
3.1.4.1. Spencer (1991)

Spencer (1991) destaca as seguintes propriedades dos nomes compostos: (i) recursividade (66), (ii) estrutura interna de constituintes (interpretação composicional) (67), e (iii) relações semelhantes às relações de sentença (núcleo-modificador, e.g., (67)a; argumentopredicado, e.g., truck driver (motorista de caminhão, lit. "caminhão motorista"); e apositiva, e.g., sofa-bed (sofá-cama)).

(66)
a. student film society
b. student film society committee
c. student film society committee scandal
d. student film society committee scandal inquiry...

(SPENCER, 1991, p. 310)

(67)
a. [student [film society]] = "sociedade estudantil de filmes"
b. $[[$ student film $][$ society $]]=$ "sociedade de filmes estudantis"

(SPENCER, 1991, p. 310)

Spencer ressalta que as propriedades acima apontadas podem ser usadas como argumento para as propostas que afirmam que os compostos sejam formados na sentença (ou em uma interface morfológica), ao invés de serem formados no léxico. Por outro lado, outras propriedades dos compostos permitem que se argumente que eles sejam formados no léxico: (i) lexicalização frequente, por meio de um desvio semântico que torna o composto não- 
composicional (opaco), ou totalmente idiossincrático (e.g., penknife (canivete, lit. "caneta faca".), um tipo de faca utilizada para cortar cálamos ${ }^{32}$ a partir de penas, e atualmente se refere a qualquer tipo de canivete), (ii) não referencialidade: não-núcleos (complementos) do composto nunca se referem a um objeto específico; sua leitura sempre é genérica, e não de um objeto em específico (cf. (60), na seção 2.2.3.1., acima), e (iii) opacidade para flexão : no caso de um composto como pickpocket (batedor de carteira, lit. "pega bolso"), sua flexão como *pickedpocket nunca poderia se referir a algo como ex-pickpocket (ex-batedor de carteira) ou pickpocket victim (vítima de batedor de carteira). Apenas a forma pickpocketed é aceita, e é a forma participial da verbalização (alguém que teve a carteira batida pode ser chamado de pickpocketed, em inglês).

Já no que diz respeito à relação translinguística, Spencer aponta que o sistema de formação de compostos nas línguas românicas, como o francês, estaria em distribuição complementar com o sistema do inglês. O francês teria duas formas produtivas de compostos; uma formada a partir de sintagmas frasais "completos", com palavras funcionais e itens lexicais flexionados (e.g., le cessez-le-feu, "cessar-fogo"), enquanto a outra forma seria um verbo seguido de seu objeto (e.g., porte-parole, "porta-voz"), ambos altamente marginais em inglês. Já compostos $\mathrm{N}+\mathrm{N}$ seriam menos produtivos em francês, e sempre denotando relações apositivas (e.g., homme-grenouille, 'mergulhador', lit. "homem sapo"), que seriam comprovadas graças à flexão dos dois elementos que formam o composto (hommesgrenouilles). Para tal fato, Spencer (1991, p.312) afirma que "Novamente, nós temos um sistema que se parece mais com a lexicalização da sintaxe do que um processo de composição morfológico, específico".

\footnotetext{
${ }^{32}$ Do inglês quill (SPENCER, 1991). A Wikipédia (http://pt.wikipedia.org/wiki/Cálamo) define cálamo da seguinte maneira:
}

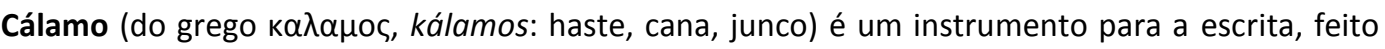
de um pedaço de cana ou junco, talhado obliquamente ou afinado na extremidade, utilizado antigamente para escrever em papiros e pergaminhos. 
3.1.4.2. Bauer (2006)

Bauer (2006) define compostos como palavras formadas por dois lexemas, ao invés de palavras formadas por duas palavras. A autora faz, porém, uma distinção entre lexema e item lexical. Enquanto lexema é a base que possui informação semântica, e pode derivar outras formas pelo acréscimo de itens flexionais, itens lexicais são qualquer coisa listada no dicionário mental de um falante.

Apesar dessa distinção, Bauer afirma que um composto não é um item lexical formado por dois lexemas, mas sim um único lexema. Essa afirmação se deve pelo fato de que apenas o segundo elemento do composto - o núcleo - é flexionado. Além disso, itens com mais de um lexema que são produto de cristalização de estrutura sintática (cf. forget-me-not, lit. "não me esqueça") ou repetição de um mesmo lexema (cf. namby-pamby, shilly-shally) não são considerados compostos, já que não são formados por duas bases (dois lexemas) independentes (BAUER, 2006, p. 485).

Bauer afirma que o núcleo dos compostos sempre é de ordem hiperonímica, ou seja, o elemento que o modifica no composto deve pertencer a um subconjunto de suas propriedades ((68), (69)):

(68)

$$
\begin{array}{ll}
\text { (68) } \quad \text { windmill } & =\text { a type of mill } \\
\text { 'vento + moinho' } & =\text { um tipo de moinho } \rightarrow \text { moinho de vento } \\
\text { (69) sky-blue } & =\text { a type of blue } \\
\text { céu }+ \text { azul } & =u m \text { tipo de azul } \rightarrow \text { azul-céu }
\end{array}
$$


A autora ainda afirma que o elemento final do composto (núcleo), além de semanticamente importante, é determinante da classe gramatical do composto e, na maioria dos casos, do seu padrão flexional:

(70) mouse-mice; flittermouse-flittermice

'rato' - 'ratos' 'morcego' - 'morcegos'

De acordo com a definição de Bauer, compostos não dependem da especialização de significados para serem considerados compostos, e formações novas e criativas, como bookmill (lit. livro + moinho $=$ moinho de livro(s), ou alguém que publica muitos livros em pouco tempo, cf. windmill, (68), acima) são consideradas por sua estrutura, e não por sua rigidez de significado; assim como How do you do? (Como vai você? / Prazer em conhecê-lo, lit. "Como (auxiliar) você faz?") é uma expressão cristalizada, compostos que não possuem significado livre são apenas cristalização de uma construção gerada por um mecanismo produtivo e livre na língua. 
3.1.4.3. Olsen (2008)

Olsen (2008) revisa uma série de trabalhos clássicos sobre compostos. De acordo com o que se observa no trabalho da autora, as propriedades destacadas através do tempo nestes estudos são os seguintes:

(71) Propriedades típicas da composição, de acordo com Olsen (2008):

(i) Um processo produtivo;

(ii) Recursivo (em alguns casos);

(iii) Compostos são vagos e ambíguos;

(iv) $\quad \mathrm{N}+\mathrm{N}$ é seu padrão mais regular;

(v) Compostos estão sujeitos a especializações de significado - mas estes significados "devem estar gravados no léxico".

Quando colocadas em contraste, as propriedades dos compostos elencadas por Olsen (2008) se aproximam bastante das propostas por Spencer (1991) e Bauer (2006) no que diz respeito à interpretação dos compostos, já que todas as propostas afirmam que a interpretação semântica dos compostos se dá composicionalmente. Por outro lado, essa afirmação vai em direção oposta ao que Basílio (1987) e Kehdi (1992) afirmam para os compostos do $\mathrm{PB}$, os quais apresentam sempre uma leitura idiossincrática em relação aos nomes dos quais se originam. 
Aparentemente, os compostos do inglês são produtos de formação sintáticomorfológica que obedecem a um determinado conjunto de restrições de formação, que apenas permite que um grupo semântico determinado (em relação hipônima/hiperônima) produza expressões nominais que obedeçam a regras de concordância, como se fossem apenas um item simples. A formação de significados especiais/cristalizados é uma possibilidade, mas, não é característica fundamental nem obrigatória.

A partir deste contraste, os compostos $\mathrm{N}+d e+\mathrm{N}$ do PB serão observados na próxima seção. O objetivo será mostrar que, apesar de essas expressões aparentarem ser sintaticamente mais complexas, elas apresentam as mesmas características semânticas dos compostos $\mathrm{N}+\mathrm{N}$ do inglês, o que permitirá propor uma análise sintática convergente entre os fenômenos do inglês e do PB.

\subsection{Propriedades das expressões nominais complexas do PB: uma comparação semântica}

\subsubsection{Uma aproximação entre os compostos do $P B$ e do inglês}

Conforme mencionado no capítulo anterior, Snyder (1995) se baseia na questão da produtividade como central para que se determine a presença de uma construção em uma determinada língua. Bauer (2006), na tentativa de definir o que é um composto, afirma que “um processo é produtivo enquanto e na extensão em que é usado na produção de formas novas" ${ }^{\prime 33}$.

${ }^{33}$ Bauer (2006, p. 484, tradução minha). 
Ao longo da literatura sobre compostos, é dito que línguas de origem românica - PB como parte deste grupo - não apresentam produtividade em seu processo de composição. Porém, como foi mostrado nas seções 3.1.2. e 3.1.3. (acima), o PB possui compostos dos mais variados tipos, e o processo de composição é considerado o mais relevante na formação de palavras, juntamente com a derivação. Por outro lado, existe uma variação semântica crucial quando os trabalhos sobre compostos no inglês e no PB são comparados. Enquanto os trabalhos do PB afirmam que os compostos são um elemento de significação nova, sem relação com as partes que o compõem, os trabalhos do inglês apenas indicam que esse é um resultado possível do processo de composição. Snyder (1995) advoga que a produtividade é o fator central para determinar a ocorrência de uma construção em determinada língua. Ou seja, se compostos em PB fossem uma forma produtiva, deveriam aparecer em casos de novas formações, e essa forma nova seria passível de utilização em contextos de significação variados. $\mathrm{O}$ que é visto em $\mathrm{PB}$, porém, é que apenas expressões de conteúdo semântico idiossincrático são produzidas, e que essas expressões apresentam, em sua maioria, leituras cristalizadas. É por conta dessa restrição de produtividade que esta tese defenderá que compostos $\mathrm{N}+\mathrm{N}$ em $\mathrm{PB}$ não são produtivos, e, por sua vez, não podem ser considerados equivalentes aos compostos $\mathrm{N}+\mathrm{N}$ do inglês.

Com base nesse contraste, surge a seguinte dúvida: existem dois tipos de composição, um que gera compostos de interpretação independente de suas partes, e outro processo que gera compostos semanticamente transparentes? Caso existam dois processos, qual seria a diferença entre eles?

Snyder (1995) defende que a formação de compostos seja um processo de afixação que também está disponível para a formação de predicados complexos, como construções verbo+partícula, por exemplo: 
“... a intuição por detrás de $(6)^{34}$ é que exista um único mecanismo permitindo

a afixação de coffee a cup no processo produtivo de composição exemplificado em (5a) $\left[N^{\circ}\left[N^{\circ}\right.\right.$ coffee $]\left[N^{\circ}\right.$ cup $]$, e permitindo afixação de up a call em um composto ocorrendo em um nível de representação mais abstrato para (4b) [= John called Mary up]."

(SNYDER, 1995, p. 27, tradução minha)

Ou seja, o Parâmetro de Composição (Snyder 1995) afirma que, em línguas em que um dos processos de formação de palavras é bloqueado (ou pouco produtivo), a formação de predicados complexos não seria possível. É crucial para esta tese que a questão do processo formador de compostos e predicados complexos seja discutida, pois é a partir dessa operação que gera todas essas construções, em conjunto com o modelo da Morfologia Distribuída, que será possível explicar a análise aqui proposta. Afinal, esse modelo sintático permite que palavras e sentenças sejam formadas no componente sintático, uma característica desejável, dada a estrutura do Parâmetro de Composição. Ou seja, esse parâmetro não exclui construções, mas o processo que gera essas construções. Dessa maneira, o que explicará a presença "inesperada" de determinadas construções em PB será a maneira com a qual este processo interage com a gramática do PB - em contraste à gramática do inglês - de modo a derivar a gama de estruturas presentes em cada língua.

Assim sendo, existiria um processo de composição capaz de gerar expressões nominais com significado especializado, permitido em PB e inglês, e outro processo, em que o

\footnotetext{
${ }^{34}$ O item (6) em Snyder (1995) é sua formulação do Parâmetro de Composição, repetida abaixo em (i):

(i) Parâmetro de Composição: a gramática (não) permite livremente que itens lexicais de classe aberta não-afixais sejam marcados como [+Afixal].
}

(SNYDER, 1995, p. 27, tradução minha) 
significado é composicional com suas partes, permitido apenas em inglês? Ou ainda, haveria algum tipo de restrição em PB que "obriga" que compostos sejam sempre interpretados como uma palavra de significado novo, dissociado das partes que o compõem?

A questão que esta tese se põe frente à possibilidade de ocorrência de compostos no PB é a seguinte: Será que existem línguas em que não seja possível expressar a relação entre dois nomes de modo a denotar uma terceira entidade, cujo significado deriva da união entre esses dois elementos, ou ainda, a simples interpretação composicional destes dois nomes?"

Jakobson (1971, p. 264) afirma que: "as línguas diferem essencialmente no que elas devem expressar, e não no que elas podem expressar". Caso se tome essa afirmação por verdadeira, não existe língua incapaz de gerar nomes compostos - ou, ao menos, expressões equivalentes derivadas por mecanismos computacionais diferentes. Seguindo essa ideia, a proposta avançada aqui é que existam componentes explícitos dentro de uma expressão nominal em PB que licenciam o mesmo tipo de relação que nomes compostos $\mathrm{N}+\mathrm{N}$ do inglês. Essas expressões, em $\mathrm{PB}$, são licenciadas pela preposição de, um elemento de natureza relacionadora (HALE; KEYSER, 2002). A preposição de seria, portanto, a responsável pelo bloqueio de leituras composicionais em $\mathrm{PB}$, enquanto seu apagamento fonológico, no inglês, permite (ou, talvez, obrigue) a formação de compostos $\mathrm{N}+\mathrm{N}$ a partir da mesma estrutura.

Para confirmar empiricamente esta hipótese, os dados abaixo são evocados, de acordo com as propriedades gerais de compostos já mencionadas. Essas propriedades são: (i) recursividade, (ii) produtividade ( $\mathrm{N}+\mathrm{N}$ sendo o padrão mais regular), (iii) interpretação variável (vaga/ambígua/composicional), (iv) significado especial (lexicalizado).

Observando os compostos $\mathrm{N}+$ de $+\mathrm{N}$, é possível notar enorme semelhança nos critérios acima observados. No que diz respeito à (i) recursividade, assim como acontece com os compostos $\mathrm{N}+\mathrm{N}$ do inglês, o PB é capaz de formar compostos $\mathrm{N}+$ de $+\mathrm{N}$ de tamanho praticamente ilimitado: 
(72) [[Bolo de [merengue de limão]] de [[dona de casa] de [cidade de interior]]] é sempre gostoso.

(Cf. '(A) countryside city's housewife lime meringue cake is always tasty', em inglês)

No caso de (ii) - produtividade/ $\mathrm{N}+\mathrm{N}$ ser o padrão mais regular do inglês -, pode ser citado o fato de que de é a palavra mais escrita no $\mathrm{PB}$, especialmente quando precedida por nomes, conforme mostrado em Villavicencio, Finatto \& Possamai (2005), baseados no Banco de Português - http://www2.lael.pucsp.br/corpora/bp/index.htm, composto então por 223 milhões de palavras.

Em outro estudo, apoiado tanto em PB quando PE, Davies \& Preto-Bay (2008) mostram que de é a segunda palavra mais usada no português - aparecendo 1.691 .442 vezes em um corpus de 20 milhões de palavras, baseado majoritariamente na seção dos anos 1900 do Corpus do Português (www.corpusdoportugues.org).

Teixeira (2009), em um estudo sobre a semântica dos nomes compostos, parte de um corpus de dez edições da revista National Geographic. Ao analisar os dados a fim de observar os correspondentes de tradução dos compostos em seu corpus, a autora observa que

“... a construção $N$ de $N$ é de fato a mais utilizada por tradutores humanos para expressar a relação entre os elementos de um composto em língua portuguesa, totalizando 91 (incluindo as expressões com artigos) das 165 ocorrências analisadas, conforme dados da tabela..."

(TEIXEIRA, 2009, p. 135) 
Além da produtividade, Teixeira ressalta o fato de que "devido ao seu aspecto polissêmico, a preposição de pode expressar qualquer uma das relações analisadas nesta seção: função, origem, material, parte, conteúdo, local, tempo e posse" (TEIXEIRA, 2009, p. $135)$.

A título ilustrativo, pode ser citado um dicionário de compostos do inglês de conteúdo aberto, o Wiktionary (http://en.wiktionary.org/wiki/Category:English compound words), existem 7.148 entradas (último acesso em 18/05/2012), enquanto na versão em português, o Wikcionário (http://pt.wiktionary.org/wiki/Categoria:Substantivo composto (Português)), existem apenas 217 entradas $^{35}$. Destas 217 entradas, 74 (34,1\%) são formadas com a preposição de. Ou seja, é inegável a produtividade de expressões com a preposição de, seja na forma de compostos lexicalizados, seja na sua forma "sintática".

Gomes (2009) também fala da abrangência da preposição de nos compostos. A autora vai contra a proposta de Neves (2000, apud GOMES, 2009), que afirma que a preposição de estabelece uma relação no tempo e no espaço; Gomes aponta que em compostos como jantar do sábado ou mesa do fundo, a preposição "de" está ali apenas como elemento de ligação entre o antecedente, e as referências de tempo ou espaço são dadas por sábado e fundo, respectivamente. A autora conclui que "... fora do contexto, o significado da preposição "de" é imprevisível, pois esta é extremamente dependente dos elementos que a antecedem e sucedem." (GOMES, 2009, p. 109). Apesar desse fato, a preposição ainda aparenta carregar algum conteúdo semântico, por mais vago que seja. Esse problema será discutido mais adiante, no capítulo 4.

\footnotetext{
${ }^{35}$ É óbvio que estas listas não correspondem à realidade lexical das línguas, nem refletem a frequência da formação de compostos em inglês ou em português. Porém, dicionários também apresentam uma infinidade de termos que fogem do conhecimento lexical da grande maioria dos falantes de qualquer língua, e, mesmo o mais culto dos falantes não é capaz de saber todas as acepções de todos os nomes compostos de sua língua. Assim sendo, a utilização dos dados aqui mencionados são por fator de ilustração, já que qualquer tentativa de formação de um corpus de compostos de inglês e PB seria tarefa que foge do escopo do trabalho aqui delineado.
} 
O fato de a preposição de apresentar um caráter genérico é um argumento importante em favor do item (iii) (interpretação variável (vaga/ambígua/composicional)). Apesar de os itens (iii) e (iv) dizerem respeito a propriedades semânticas opostas - já que é impossível ser vago e apresentar um significado especializado ao mesmo tempo -, a relação entre composicionalidade e lexicalização é muito próxima quando se observa a formação de compostos pelo panorama da Morfologia Distribuída, e o papel da preposição de se revelará crucial para explicar as diferenças entre PB e inglês. Este fato será discutido na seção 3.3.2.

Pensando na questão da lexicalização das expressões com de em contraposição à liberdade de formação de compostos de interpretação livre/composicional no inglês, é possível ver que a preposição de mostra o mesmo tipo de ambiguidade que um composto quando em contraste com uma expressão com a preposição para no PB (73), abaixo. Ou seja, expressões em PB com de também possuem informações implícitas, dependentes de contexto.

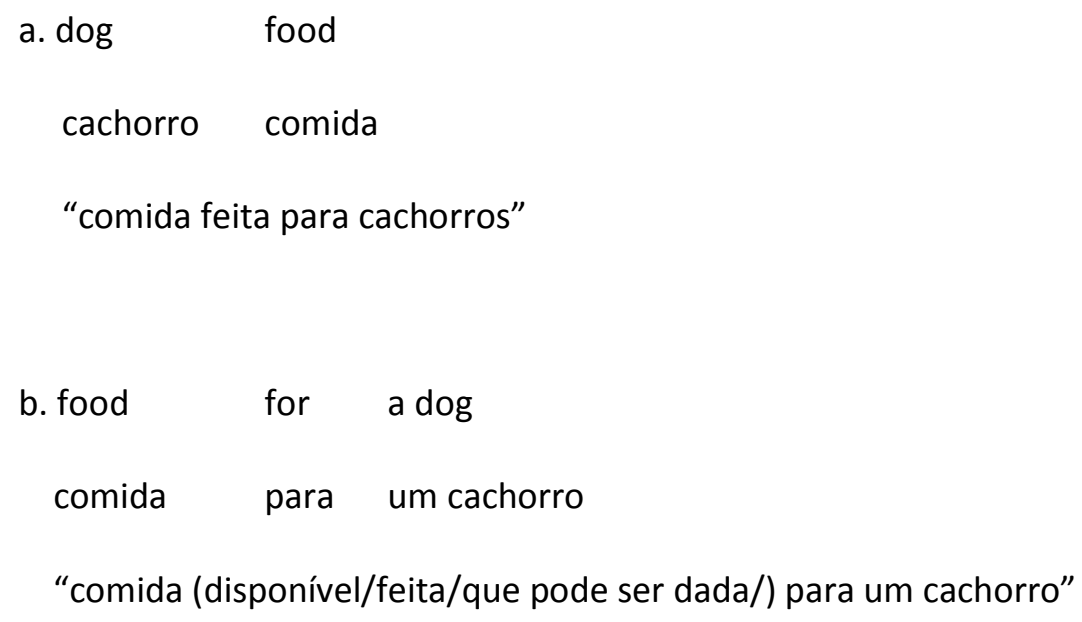

(OLSEN, 2008, p.10)

c. comida de cachorro

d. comida para cachorro 
O mesmo pode ser dito dos dados de (74) e (75). Dependendo do elemento que modifica o núcleo das expressões com de no PB, surge uma interpretação idiomática, que depende de conhecimento extralinguístico para sua interpretação, assim como a palavra pancake (panqueca), cuja interpretação não corresponde à interpretação de suas partes, pode ser decomposta em pan (frigideira) + cake (bolo) $=$ (lit. 'bolo de frigideira'), mas carrot cake (bolo de cenoura) mantém sua interpretação literal. Um argumento interessante pode ser notado em (74). Enquanto o PB faz uma distinção entre (74)b e (74)c, o mesmo nome composto denota os dois objetos no inglês (74)e-f. No caso dos contrastes entre (75)b-c e (75)e-f, a expressão do PB em (75)c é equivalente a um único item lexical do inglês.

(74)
a. colher de brinquedo
b. colher de madeira
c. colher de pau
d. toy spoon
brinquedo colher
"colher de brinquedo"
e. wooden spoon
"madeiral" colher
"colher de madeira"
f. wooden spoon
"madeiral" colher
"colher de pau" 
(75)
a. cara de boneca
b. cara de madeira
c. cara de pau
d. doll face
boneca rosto
"cara de boneca"
e. wooden face
"madeiral" rosto
"cara de madeira"
f. chutzpah ${ }^{36}$
"cara de pau"

É importante destacar que não apenas expressões $\mathrm{N}+\mathrm{N}$ possuem equivalentes em $\mathrm{PB}$ por intermédio da preposição de; compostos adjetivais como (76), por exemplo, aparentam ter as mesmas propriedades quando convertidas em expressões $A+d e+A$. Os adjetivos que são núcleos da expressão (à direita, no inglês; à esquerda, no PB) recebem um tipo de modificação de grau, equivalente a um advérbio/locução adverbial de modo (cf. (76)a"-b" e (76)a"'-b"'). 0 interessante é que este tipo de composição é extremamente distinto da contraparte sintática em (77) (abaixo), que também usa a preposição de (of, no inglês); por outro lado, a expressão em colchetes indica o complemento do adjetivo, e não o grau deste.

\footnotetext{
${ }^{36}$ A palavra chutzpah advém de um empréstimo do hebraico, cujo significado na língua de origem é audácia ou insolência.
} 
(76)

a. I'm dead tired.

a'. Eu estou morto de cansado/cansaço.

a". I'm extremely tired.

a'". Eu estou extremamente cansado.

b. The kids are crazy hungry.

$b^{\prime}$. As crianças estão doidas de fome.

$b^{\prime \prime}$. The kids are very hungry.

b'". As crianças estão com muita fome/muito famintas.

c. The students are zombie sleepy.

c'. Os alunos tão zumbis de sono/mortos de sono/acabados de sono.

$c^{\prime \prime}$. The students are quite sleepy.

c'". Os alunos estão com muito sono/muito sonolentos.

(77) a. I am tired [of waiting for the bus].

a'. Eu estou cansado [de esperar pelo ônibus].

b. Her parents are proud [of her good grades].

$b^{\prime}$. Os pais dela estão orgulhosos [de suas notas boas].

De acordo com os dados apresentados até aqui, surge um problema quanto à classificação do que é composto, seja em PB, seja em inglês; foi visto acima que os compostos do $\mathrm{PB}$ formados por $\mathrm{N}+$ de $+\mathrm{N}$ são de caráter produtivo, o que evidencia sua capacidade de interpretação não-lexicalizada, assim como os compostos $\mathrm{N}+\mathrm{N}$, representantes característicos do processo de composição do inglês. Logo, é possível afirmar que PB possui o processo de composição, e que também forma unidades no nível da palavra. A diferença é que, enquanto compostos $\mathrm{N}+\mathrm{N}$ do inglês são representantes tanto de formas composicionais livres quanto de 
formações com significação especial, o PB apresenta compostos $\mathrm{N}+\mathrm{N}$ apenas para formações de significação especial, enquanto expressões $N+d e+N$ representam o equivalente ao inglês, formando tanto compostos lexicalizados quanto compostos livres.

Além disso, também foi visto que estes compostos do PB também correspondem a grande porcentagem do número de compostos de significado especial que não resulta de suas partes (lexicalizados). Da mesma maneira, os compostos do inglês de forma $\mathrm{N}+\mathrm{N}$ são altamente produtivos, e são grande parte das expressões nominais cristalizadas.

Um contraponto que poderia ser argumentado é o seguinte: Snyder (1995) afirma que um composto do francês - uma língua românica, marcada negativamente para o Parâmetro de Composição assim como PB - como tasse à café (copo de café) é o equivalente sintático de coffee cup, e, ao contrário do inglês, a expressão do francês não pode ser considerada uma unidade no nível da palavra. Logo, expressões $\mathrm{N}+$ de $+\mathrm{N}$ seriam produto de formação sintática, exceto quando sua união resulta em uma palavra com novo significado. Porém, os dados acima não permitem ignorar a semelhança semântica entre compostos $\mathrm{N}+d e+\mathrm{N}$ do PB e os compostos $\mathrm{N}+\mathrm{N}$ do inglês, o que faz crer que exista uma semelhança sintática entre essas expressões, em algum momento da sua formação.

Por consequência da distinção entre "interpretação especial dos compostos surge no léxico" versus "interpretação composicional é feita na sintaxe", a distinção entre $\mathrm{N}+\mathrm{N}$, formado no léxico e $\mathrm{N}+d e+\mathrm{N}$, formado na sintaxe, pode explicar a formação de compostos do inglês como paralela à formação de compostos $\mathrm{N}+d e+\mathrm{N}$ do $\mathrm{PB}$. Se os compostos do inglês são interpretados como uma palavra morfologicamente complexa, devem ser formados no léxico. Apesar disso, a produtividade de expressões $\mathrm{N}+\mathrm{N}$ é enorme, fato geralmente correspondente à expressões sintáticas, e não lexicais.

Assim sendo, ao invés de afirmar que compostos $\mathrm{N}+\mathrm{N}$ interpretados de maneira composicional são formados na sintaxe - o que seria um problema para a distinção 
léxico/sintaxe -, a hipótese a ser desenrolada nesta tese é a de que os compostos do inglês são gerados como $\mathrm{N}+d e+\mathrm{N}$, e outros processos fazem com que o produto final seja $\mathrm{N}+\mathrm{N}$; essas questões serão explicadas com base no modelo da Morfologia Distribuída, em especial a noção de Marantz (2001) para a definição de palavra, e para determinar as questões de interpretação especial nos compostos. Na próxima seção, o trabalho de Marantz é exposto, de modo a auxiliar na análise dos compostos do PB e do inglês.

3.2.2. Marantz (2001) e a questão da idiomaticidade: explicando a interpretação composicional

Em um texto que defende a existência de apenas um componente computacional responsável pela formação de sentenças e palavras, Marantz (2001), dentro do panorama da Morfologia Distribuída, propõe que a noção clássica de "dois lugares" para a formação de objetos computacionalmente complexos, atribuídos previamente ao léxico (para a formação de palavras) e à sintaxe (para a formação de sentenças) seja substituída por composição gerada apenas na sintaxe, a partir das relações estruturais - posições na árvore sintática - e derivacionais dos itens presentes na estrutura sintática, envolvendo, segundo o autor, domínios cíclicos. Dessa forma, Marantz faz as seguintes afirmações: 


\begin{abstract}
“A uniformidade da morfofonologia advém da natureza interpretativa da [própria] morfofonologia, que uniformemente forma a sintaxe."

"A uniformidade da composicionalidade advém do fato de a sintaxe realizar todas as operações de concatenação [merger], incluindo aquelas entre morfemas nos limites da palavra."
\end{abstract}

(MARANTZ, 2001, p. 6, tradução minha)

Seguindo essa proposta, Marantz propõe que existam duas maneiras de formar uma palavra derivacionalmente. Na primeira, pode-se unir morfemas (head, cf. (78)a, abaixo) a uma a raiz, que, por sua vez, será então categorizada (nome, verbo, adjetivo, etc.). A outra maneira de formar palavras é modificando essa raiz já categorizada, onde um elemento $x(n, a, v)$ intervém entre a raiz e esse morfema formador de palavra (head em (78)b).

(78) a.

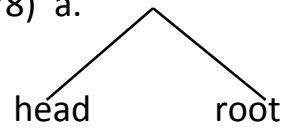

b.

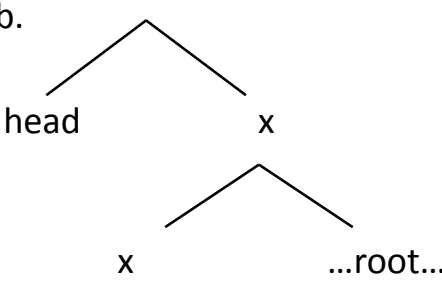

(MARANTZ, 2001, p. 6)

Marantz (2001) afirma que esses núcleos ( $x$, correspondentes aos núcleos $n, v$, ou $a$ ) determinam a "borda" de um domínio cíclico, ou uma fase, nos termos de Chomsky (1999). Ou seja, morfemas que se unem à raiz antes da inserção desse núcleo $x$ ainda estão no domínio da palavra (78)a, enquanto morfemas que não são c-comandados por $x$ estão fora desse domínio (78)b. A estrutura formada pela união da raiz com esse núcleo x é enviada para LF e PF para interpretação fonológica e semântica, e o significado da raiz no contexto de x"zinho" é "negociado", nos termos de Marantz, usando conhecimento Enciclopédico (lista 3; cf. seção 
1.4., acima). Assim, núcleos que se unem a x"zinho" selecionariam como complemento uma estrutura em que o significado (e a pronúncia) já teriam sido negociados (79):

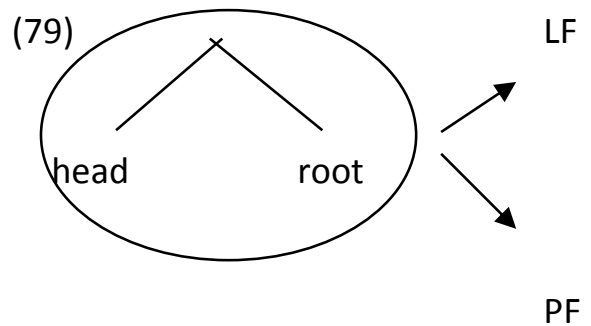

PF

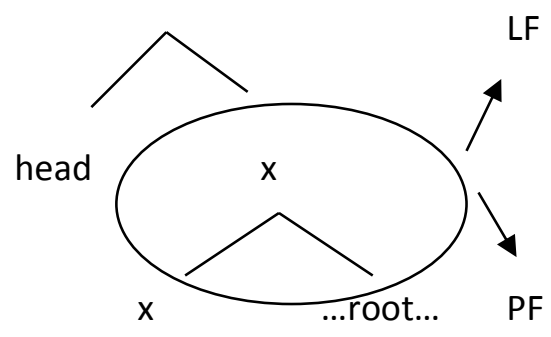

(MARANTZ, 2001, p. 7)

Marantz argumenta que, "se um núcleo se concatena fora de x"zinho", ele vê os traços de $\mathrm{x}$ localmente, mas não os traços, propriedades, ou identidade da raiz concatenada com $\mathrm{x}^{\prime \prime 37}$. Nesse caso, as propriedades de seleção de um núcleo são satisfeitas pelos traços de $x$, e não pelas propriedades da raiz, que são, segundo Marantz, "idiossincráticas à língua e ao falante individual" (80)b. Se o núcleo se une à raiz, os requerimentos de seleção passam a ser satisfeitos pelas propriedades idiossincráticas da raiz (80)a:

(80) a.

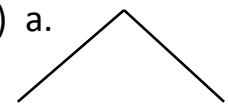

head $\longrightarrow$ root b.

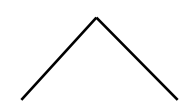

head
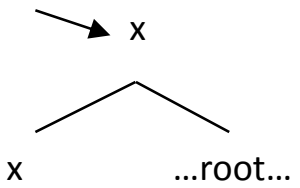

...root...

domínios de localidade para seleção

(MARANTZ, 2001, p.7, tradução minha)

\footnotetext{
${ }^{37}$ Marantz, 2001, p.7.
} 
Com a proposta de Marantz, tem-se um instrumental teórico que explicaria a noção de "dois lugares" para formação de palavras. As propriedades clássicas de palavras "formadas no léxico" e palavras "formadas na sintaxe" se dão pela junção dos morfemas derivacionais no domínio de localidade relevante para a sua interpretação.

Com a diferença estrutural ressaltada acima, ficam explicadas, sem a necessidade de um léxico, as oposições (i) interno vs. externo, (ii) semiprodutivo vs. produtivo, (iii) tem a ver com a semântica das raízes vs. tem a ver com a estrutura argumental sintática, (iv) é associado com significados especiais vs. é associado com significados previsíveis. Dizer que essas relações estão diretamente ligadas aos núcleos categorizadores de raízes explicará a relação entre os compostos do inglês e do PB, apesar de suas formas superficiais distintas.

Antes de relacionar as noções de Marantz aos compostos, é necessário determinar qual a estrutura sintática para os compostos. Na próxima seção, o trabalho de Di Sciullo (2005) é tomado como ponto de partida para a definição da estrutura que aproxime os compostos do inglês e do PB, de acordo com a aproximação observada empiricamente na seção 3.2.1., acima.

\subsection{Uma nova proposta de análise para os compostos a partir dos dados do PB}

\subsubsection{Di Sciullo (2005) e a projeção $F$}

Di Sciullo (2005) faz uma proposta para a estrutura de compostos com base no seguinte argumento: seja qual for a relação entre os membros do composto ((i) núcleomodificador, que a autora chama de composto raiz; (ii) argumento predicado, chamado de 
composto deverbal e (iii) apositivos, chamados de dvandva), nomes compostos possuem uma propriedade em comum: todos incluem uma projeção funcional. Em sua Teoria de Assimetria, a autora também argumenta que a ordem de constituintes desses compostos se dá pelo fato de que, se a relação dos compostos é simétrica (exocêntrica), ela ocorre em um plano morfológico, enquanto relações assimétricas (endocêntricas) são manipuladas em um plano sintático do espaço computacional.

Segundo a autora, essa projeção funcional pode ter ou não realização fonológica. Porém, o núcleo sempre é legível no nível de interpretação semântica (Forma Lógica (LF)). Modificadores $(\alpha)$ ocupariam a projeção de especificador dessa projeção funcional, enquanto o núcleo do composto ocupa a posição de complemento ( $\beta$ ) (cf. (81), abaixo). O núcleo dessa projeção pode ser realizado por uma raiz (possivelmente uma preposição) ou um afixo.

(81)

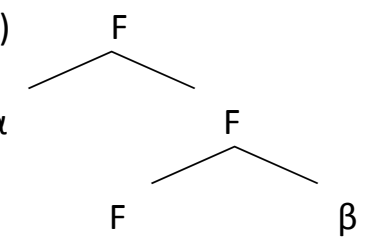

Para argumentar em favor dessa estrutura para os compostos, Di Sciullo (2005) aponta o fato de que os compostos raiz (ou endocêntricos, ou núcleo-modificador, na terminologia de SPENCER, 1991) incluiriam uma relação de modificação (82). Um segundo argumento em favor da hipótese da árvore-F é que a árvore-F deve ser parte da estrutura dos compostos por considerações da legibilidade da interface. Assim, um conectivo deve ser legível em PF nos compostos dvandva, tais como em (83), os quais não são bem formados de outra maneira. 
a. black board, happy hour, floppy disk

'quadro negro', 'hora feliz', 'disco flexível'

b. blue gray, pink orange, dark beige

'cinza azulado', 'laranja rosado', 'bege escuro'

c. fountain pen, ash tray, golf ball

'caneta-tinteiro', 'cinzeiro (lit. bandeja de cinzas)', 'bola de golfe'

(83)

a. bed-and-breakfast, hit-and-run, truth-or-dare

b. *bed-breakfast, *hit-run, *truth-dare

c. vai-e-vem, sobe-e-desce, verdade-ou-desafio

(Adaptado de DI SCIULLO, 2005, p. 17) ${ }^{38}$

Assim sendo, conjunções e disjunções seriam categorias funcionais, cujas presenças nos compostos fornecem evidência de que compostos incluem uma projeção funcional. Há três tipos de operadores que podem nuclear a projeção funcional: AND, OR ou SORT. Enquanto os dois primeiros aparecem em compostos de relação apositiva (dvandva), SORT aparece nos compostos de relação núcleo-modificador (compostos-raiz):

\footnotetext{
${ }^{38}$ É possível notar a partir de (83)c que, no $\mathrm{PB}$, compostos dvandva poderiam não apresentar conectivos fonologicamente realizados, como no caso de vaivém, e sobe-desce. Porém, parece que esse "desaparecimento" do conectivo é, na verdade, um caso de assimilação fonológica dada sua semelhança vocálica com a terminação do primeiro elemento do composto. Por outro lado, compostos desse tipo que terminam em outras vogais não permitem essa suposta ausência do conectivo (ii), com exceção de compostos formados por repetição da mesma palavra (iv), em que o conectivo não pode ocorrer:
}

(i) compra-e-vende, chega-e-sai, pega-e-larga.

(ii) *compra-vende, ${ }^{*}$ chega-sai, * pega-larga.

(iii) pega-pega, esconde-esconde, (carrinho) tromba-tromba

(iv) *pega-e-pega, *esconde-e-esconde, (carrinho) tromba-e-tromba 
(84) Estrutura funcional dos compostos com operadores (conjunções)

a.

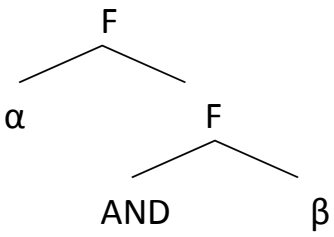

b.

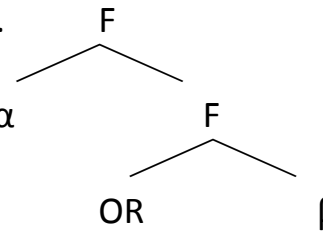

c.

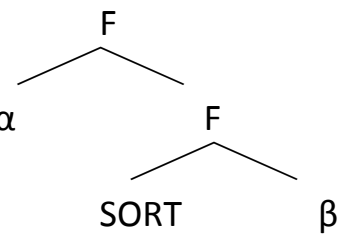

(DI SCIULLO, 2005, p. 17)

Assim como Spencer (1991), Di Sciullo diz que os compostos do inglês são derivados no domínio morfológico e os compostos do francês são derivados no domínio sintático. Por conta disso, nos casos em que os compostos são formados na sintaxe, como o francês, uma operação morfológico-sintática inverteria a ordem dos especificadores e complementos da projeção F.

Na próxima seção, a projeção F será adaptada aos moldes da Morfologia Distribuída, de modo a explicar a relação entre os compostos do inglês e PB.

3.3.2. A projeção F na Morfologia Distribuída: analisando os compostos do inglês e do PB

Tendo em mente a discussão apontada por Spencer (1991), é visível que a formação de compostos sempre foi um objeto de debate dentro das teorias sintáticas e morfológicas acerca da estruturação do léxico e dos fenômenos que nele podem (ou não) ocorrer. Porém, se compostos e expressões $\mathrm{N}+$ de $+\mathrm{N}$ - consideradas como expressões derivadas sintaticamente - são, de fato, expressões sintáticas distintas que expressam o mesmo conteúdo semântico, 
qual seria a necessidade de pensar que nomes compostos sejam de fato, formados em um lugar diferente de sentenças?

Já não é novidade na teoria gerativista a ideia de que exista um paralelismo entre nomes e sentenças (e.g., ABNEY, 1987, inter alia). Conforme descrito acima na seção 2.3., a teoria da Morfologia Distribuída propõe que qualquer formação que necessite lidar com operações computacionais para formar estruturas - sejam elas estruturas de palavras ou de sentenças - deva ser gerada em um único componente gerativo - neste caso, o componente sintático.

A proposta aqui apresentada sugere que, apesar de possuírem propriedades ditas "do léxico", compostos sejam gerados na sintaxe ${ }^{39}$. A partir do arcabouço teórico da Morfologia Distribuída, juntamente com as noções de variação paramétrica abordadas na seção 1.1.1. (acima), acredita-se que, para dar conta das relações paramétricas descritas no Parâmetro de Composição de Snyder (1995, 2001), seja necessário postular uma estrutura sintática que seja comum tanto aos compostos de línguas germânicas como o inglês quanto aos compostos de línguas românicas como o PB. Ao mesmo tempo, essa estrutura explicaria a variação entre essas línguas por meio de traços, que se acredita ser a maneira mais adequada de explicar a disparidade sintática entre os compostos de línguas germânicas e românicas vistas por Spencer (1991) e Di Sciullo (2005). No capítulo 4, a utilização de traços será motivada por meio de uma explicação teórica, de modo a ressaltar a relação empírica observada entre a presença de predicados complexos e nomes compostos.

É possível observar que, nos compostos do inglês, apenas aqueles que são classificados como endocêntricos respeitam a right-hand rule (WILLIAMS, 1981), que afirma que o núcleo dos compostos deve sempre estar à direita. No PB, estes compostos nunca aparecem lexicalizados com a preposição de, o que faz ser possível afirmar que os compostos de

\footnotetext{
${ }^{39}$ Para uma análise do fenômeno de composição baseada na Morfologia Distribuída, cf. Minussi (2008).
} 
formação endocêntrica nunca possuem interpretação composicional, e são sempre produto de lexicalização de significado.

Assim sendo, apenas nos casos endocêntricos (em que um dos membros do composto é o núcleo), o processo de composição opera livremente no inglês, o que explicaria a ordem distinta entre núcleos ((85)a e (85)c e não-núcleos ((85)b, (85)d):

(85) Comparação entre compostos do inglês e PB, divididos por relação sintática:

a. Relações núcleo-modificador (endocêntricas)

i. student film society = sociedade de filme de estudante(s)

b. Relações argumento-predicado (exocêntricas)
(ii) pick pocket
(v) fura-olho
(iii) cut-throat
(vi) quebra-galho
(iv) lazy-bones
(vii) risca-faca

c. Relações argumento-predicado (endocêntricas)

(viii) truck driver $=$ motorista de caminhão

(ix) jet pilot $\underline{\emptyset}=$ piloto de jato

d. Relações apositivas (exocêntricas)
(x) mother-child (relationship)
(xiii) (relação) mãe (e) filho
(xi) sofa-bed
(xiv) sofá-cama
(xii) bed and breakfast
(xv) entra (e) sai

Enquanto Di Sciullo (2005) afirma que a estrutura de projeção funcional F pode sofrer uma operação de espelhamento, se o composto é formado na parte sintática da derivação, a análise a ser proposta aqui é que a projeção F seja uniforme, respeitando sempre o Axioma de Correspondência Linear (Linear Correspondence Axiom (LCA), KAYNE, 1994). Na estrutura 
proposta, o elemento determinado (o núcleo semântico do composto) ocupa a posição de especificador, e o elemento determinante ocupa a posição de complemento. Dessa forma, a estrutura para um composto do PB seria como (86), com o operador sort ${ }^{40}$ fazendo o papel de núcleo da construção:

(86)

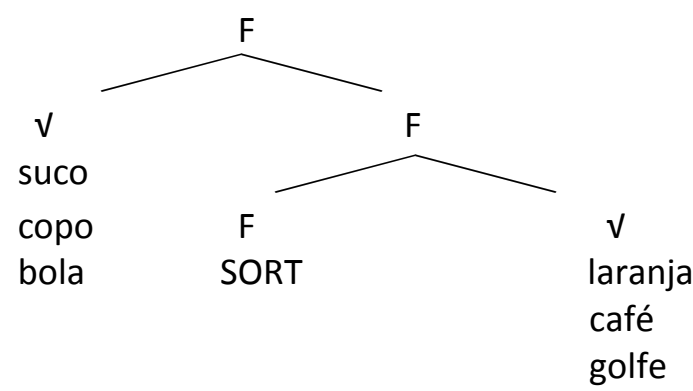

Na estrutura acima, os elementos se relacionam graças ao conteúdo relacionador da preposição. De acordo com Hale \& Keyser (2002), preposições são elementos birrelacionais por natureza, pois "especificam uma relação (espacial, temporal, ou outra) entre duas entidades (ou dois eventos, circunstâncias, etc.)". (HALE; KEYSER, 2002, p.8). Este tipo de relação estrutural é totalmente compatível com as propriedades semânticas dos compostos que foram mostradas nas seções anteriores, frequentemente tidas como vagas e abrangentes.

Apesar de núcleo, a raiz suco não pode, por si só, selecionar um elemento como laranja de maneira autônoma, já que não possui informações de seleção em seu conteúdo. Ou seja, a preposição de é quem faz a seleção tanto do determinado (complemento) quanto do determinante (especificador) do composto. Seguindo as noções de categorização de Marantz (2001), a categorização das raízes é necessária para que se determinem as funções sintáticas

\footnotetext{
${ }^{40}$ Mais adiante, será proposto que os traços [posse] e [locativo], desencadeadores do conteúdo fonológico de, derivem as mesmas propriedades que um operador do tipo SORT, como o proposto por Di Sciullo (2005).
} 
das mesmas. Assim, um nó funcional $n$ seleciona a estrutura em (86), gerando a estrutura em (87):

(87)

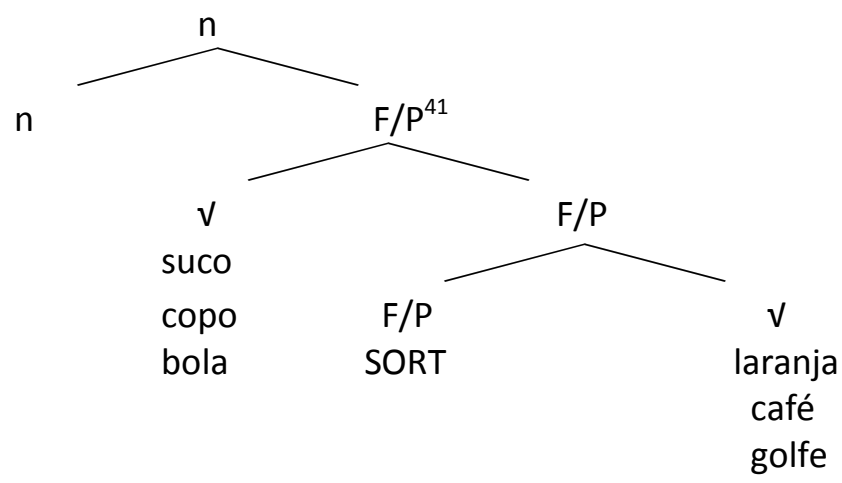

O detalhe mais relevante dessa estrutura é que, enquanto categorizador de $F, n$ permite que a estrutura como um todo tenha sua "negociação de significado" resolvida na lista 3, a Enciclopédia. Quando existe, no conhecimento de mundo do falante/ouvinte, uma interpretação não-composicional da estrutura, o composto é interpretado como um único item. Quando não há correspondência, a estrutura é interpretada de maneira composicional.

Dessa forma, se explica a produtividade dos compostos $\mathrm{N}+$ de $+\mathrm{N}$ nas expressões "lexicalizadas", ao mesmo tempo em que se explica a produtividade e interpretação vaga / composicional permitida por tal formação estrutural.

No caso do inglês, a estrutura seria a mesma; a interpretação da relação seria dada da mesma maneira, e a estrutura seria a seguinte:

\footnotetext{
${ }^{41}$ É possível que a projeção $\mathrm{F}$ seja, de fato, $\mathrm{P}$, nos casos acima. Porém, a terminologia será mantida até o capítulo 5, quando será discutida a relação entre projeções diádicas (Hale \& Keyser 2002) e a formação de predicados complexos.
} 
(88)

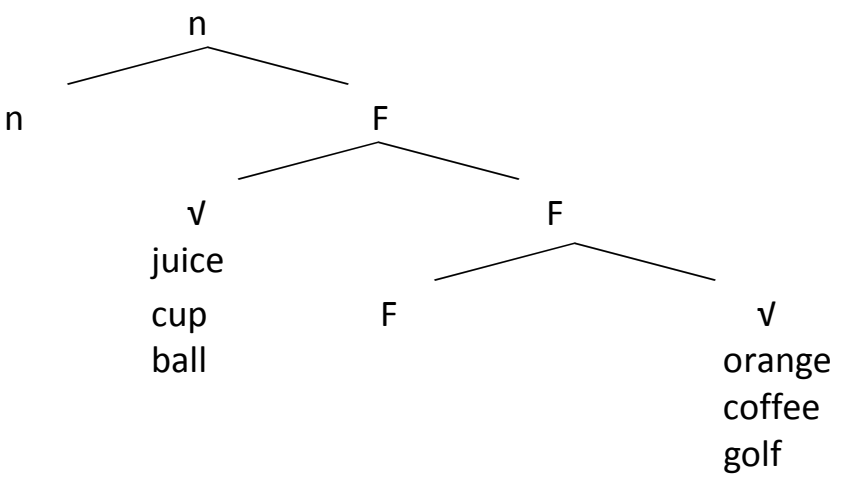

Com a estrutura acima, surge a seguinte questão: como explicar a diferença linear dos núcleos em inglês, e a ausência da preposição equivalente a de? Pelo que foi mostrado ao longo deste capítulo, os compostos do inglês e do PB são equivalentes semanticamente. Logo, a estrutura sintática dos compostos do inglês deve ser idêntica em Forma Lógica (LF), para que sua interpretação se mantenha a mesma do PB. Neste momento, a Morfologia Distribuída apresenta a maneira ideal de lidar com essa questão. Enquanto a estrutura encaminhada para LF permanece inalterada, a estrutura que sofre alterações e inserções do componente morfológico, no caminho para PF é alterada. Para tal, é postulada a regra morfológica de deslocamento compulsório, em (89)a, e a estrutura resultante da aplicação de (89)a sobre (88) é (89)b:

Um elemento ocupando a posição [Comp, F] deve se concatenar a [Spec, F], sempre que F não tiver conteúdo fonológico. 
b.

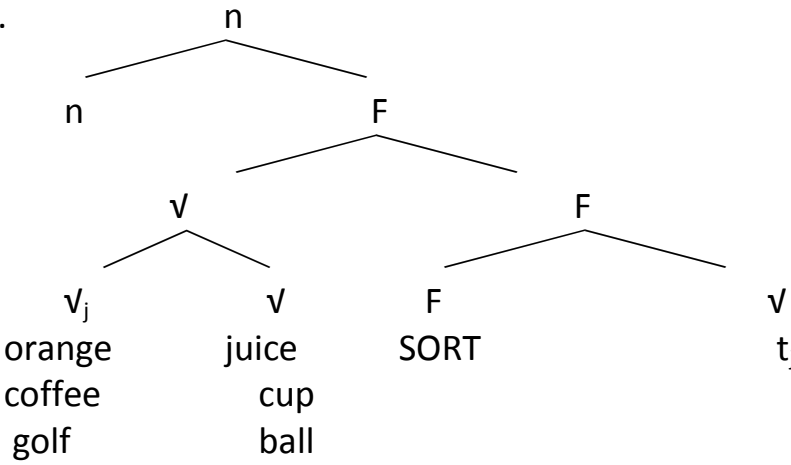

É importante notar que essa operação não ocorre nos compostos $\mathrm{N}+d e+\mathrm{N}$ do $\mathrm{PB}$. Caso deslocamento compulsório ocorresse livremente, ou compostos do PB com a forma $\mathrm{N}+\mathrm{N}$ cujos núcleos semânticos são sempre à esquerda também sofreriam este tipo de movimento, o que geraria estruturas não existentes na língua.

Para restringir a aplicação da regra de deslocamento compulsório, é necessário que a língua seja marcada positivamente para o Parâmetro de Realização Fonológica de Núcleos:

(90) Parâmetro de Realização Fonológica de Núcleos

Uma língua permite que uma projeção funcional $\mathrm{F}$ omita o conteúdo fonológico de seu núcleo em PF.

$$
\begin{aligned}
& \{\operatorname{sim}\}=\text { inglês } \\
& \{\text { não }\}=\text { PB }
\end{aligned}
$$

A partir da estrutura em (89)b, ainda se mantém o problema de linearização da estrutura, pois não há c-comando assimétrico entre o núcleo e seu complemento, ao contrário da estrutura proposta para o PB (que se mantém em PF).

Embick (2007) propõe uma operação de linearização baseada em propriedades de Deslocamento Local, no qual elementos que pertencem ao grupo que Embick chama de 
subpalavra (elementos morfologicamente dependentes) sofrem um processo de linearização inverso; dentro dessas subpalavras, o elemento mais baixo da relação de c-comando é aquele que precederá o elemento que o c-comanda.

Assim, palavras como ferrovia, que poderiam ser consideradas etimologicamente como um composto derivado de via de ferro (91) e hoje são interpretadas como um item lexical único, poderiam ter sua estrutura como a vista em (92) em algum momento da história, e suas propriedades de subpalavra a fariam ser linearizada de maneira correta, apesar da raiz via c-comandar a raiz ferro.

(91)

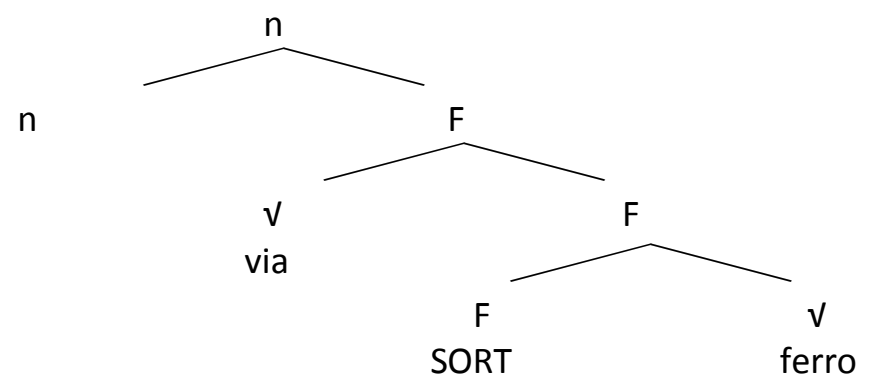

(92)

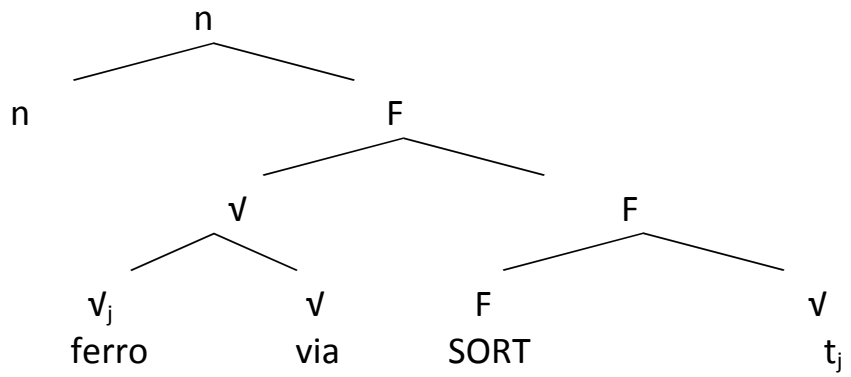

É extremamente desejável que palavras dessa natureza possuam a mesma estrutura dos compostos, apesar de utilizarem afixos derivacionais, já que o Parâmetro de Composição (SNYDER, 1995) afirma que os elementos do composto em línguas como o inglês apresentariam uma propriedade [+Afixal]. Ou seja, a mesma estrutura que forma palavras 
como ferrovia através de afixos ${ }^{42}$ em qualquer língua - inclusive $\mathrm{PB}$, que não é marcada positivamente para o Parâmetro de Composição - formaria compostos, já que, em inglês, qualquer raíz pode ser vista como um afixo. Desse modo, a análise aqui proposta é totalmente compatível com os argumentos levantados por Snyder (op. cit.), apesar da divergência quanto à representação estrutural de variação de estrutura de compostos quando são comparados PB e inglês. Por conta dos argumentos apresentados ao longo do capítulo, acredita-se que a estrutura proposta para os compostos do inglês em (89)b se justifique do ponto de vista sintático.

Com a análise delineada acima, acredita-se ter uma proposta uniforme para os nomes compostos, capaz de explicar a assimetria entre compostos exocêntricos e endocêntricos, além de mostrar que a variação de traços na projeção funcional F é o fator responsável pela diferença na formação de nomes compostos entre (pelo menos) PB e inglês.

\subsection{Conclusão}

Neste capítulo, foi argumentado que, ao contrário do que sempre foi proposto na literatura que afirma que línguas como o inglês apresentam um tipo de formação lexical peculiar, que está ausente em línguas românicas, existem equivalentes semânticos de compostos em línguas como o PB, e sua variação em forma é produto de um parâmetro que

\footnotetext{
${ }^{42}$ Neste caso, assume-se que -via seja interpretado como um afixo, dada a sua produtividade em outros itens, como rodovia, hidrovia, aerovia, dutovia, mas que não apresentam formação análoga a via de ferro (cf. *via de rodas, ?via de águas, *via de ares e ?via de dutos).
} 
condiciona a marcação fonológica a determinadas operações sintáticas que fazem com que, no inglês, uma estrutura sintaticamente idêntica à do PB em LF seja transformada de tal modo que aparente ser um tipo de formação lexical.

Com a análise acima proposta, acaba o problema clássico do caráter híbrido dos compostos; a formação dessas construções é sintática, assim como todos os objetos manipulados por ela; não existe a necessidade de um elemento formador de expressões que unem som e significado; as operações ditas lexicais são realizadas pela sintaxe, e, a variação entre compostos "lexicalizados" e compostos "composicionais" se dá pela presença de uma interpretação armazenada em seu conhecimento enciclopédico, que interpreta a estrutura categorizada como uma única palavra opaca, ou como uma palavra de interpretação baseada nas raízes que a compõem.

No próximo capítulo, as construções dativas e de objeto duplo, e a mesma estrutura proposta para os compostos será estendida aos dados da chamada alternância dativa, de modo a explicar, de maneira estrutural, a relação entre compostos e predicados complexos, a partir de um único sistema gerador de expressões "lexicais" ou sintáticas: a componente computacional. 


\section{Capítulo 4}

\section{Derivando a alternância dativa a partir do}

\section{Parâmetro da Realização Fonológica de}

\section{Núcleos}

Neste capítulo, o objetivo é analisar as construções que compreendem o fenômeno chamado de alternância dativa - construções dativas e construções de objeto duplo rotuladas de predicados pseudo-complexos no capítulo 2 .

A proposta de Snyder $(1995,2001)$ relaciona nomes compostos e construções de alternância dativa por meio de evidências de aquisição, afirmando que ambas possuem a mesma estrutura. Na análise apresentada no capítulo anterior, foi proposto que a estrutura de compostos não seja exclusividade do inglês, e que a variação entre PB e inglês é muito mais consequência de um conjunto de restrições e operações que ocorrem no caminho da estrutura sintática para PF do que uma mera ausência do fenômeno sintático em PB.

Para provar que a formação das construções participantes da alternância dativa compartilha propriedades comuns à formação de nomes compostos, a comparação dos dados de PB e inglês se torna imprescindível, mais uma vez. A partir da observação das propriedades semânticas dos dados da alternância dativa do inglês, será possível propor uma estrutura 
comum para os dois grupos de fenômenos (compostos $\mathrm{N}+\mathrm{N}$ versus $\mathrm{N}+$ de $+\mathrm{N}$, e construções de objeto duplo versus construções dativas).

Acreditando na formação de nomes compostos no PB, a premissa deste capítulo é que as construções dativas sejam sintaticamente equivalentes às expressões $\mathrm{N}+d e+\mathrm{N}$, porém, no âmbito verbal. Dessa forma, as construções de objeto duplo seriam excluídas do PB a partir dos mesmos axiomas que restringem a realização obrigatória de um núcleo da projeção funcional $\mathrm{F}$ em $\mathrm{PB}$, enquanto a possibilidade de ausência de fonologia neste núcleo do inglês desencadeia o fenômeno tradicionalmente conhecido como alternância dativa. A diferença entre as estruturas nominais e verbais é dada exatamente pelo tipo de núcleo que seleciona e categoriza $\mathrm{F}$ ( $n$ e $v$, respectivamente), o qual explica as diferenças sintáticas vistas entre os compostos e as construções de alternância dativa.

Apoiando-se em trabalhos que afirmam que as construções de objeto duplo sejam derivadas a partir das construções dativas (e.g., LARSON, 1988, PESETSKY, 1995, HARLEY, 2002), será mostrado que essas análises possuem um problema quanto à necessidade de duas estruturas distintas para a interpretação semântica entre construções dativas e de objeto duplo. Dados do PB mostram que as interpretações ditas "exclusivas" das construções de objeto duplo estão disponíveis em dativas (pelo menos no PB). Com base nos trabalhos de Bresnan \& Nikitina (2008) para o inglês, e Scher (1996) e Armelin (2011) para o PB, serão apresentados argumentos que invalidam a hipótese de que construções de objeto duplo sejam especiais no que diz respeito às suas restrições semânticas, quando comparadas às construções dativas.

Após a apresentação dos testes relevantes para a discussão, será proposta uma extensão da análise para os nomes compostos feita no capítulo 3 , de modo que a projeção $F$ seja responsável também pela representação estrutural dos argumentos dos verbos que participam das construções dativas. 
A mesma restrição paramétrica que proíbe a formação de nomes compostos $\mathrm{N}+\mathrm{N}$ em PB seria a responsável por derivar o bloqueio de construções de objeto duplo no PB, um resultado compatível com a restrição translinguística que o trabalho de aquisição feito por Snyder $(1995,2001)$ propõe. Porém, a atenção aqui será voltada para a questão da influência do conteúdo fonológico das preposições sobre os reflexos informacionais em jogo na escolha de uso entre construções de objeto duplo e construções dativas no inglês (BRESNAN; NIKITINA, 2008), bem como a anulação dos conhecidos efeitos de assimetria entre dativas e construções de objeto duplo (cf. BARSS; LASNIK, 1986). Na próxima seção, a definição clássica da alternância dativa será apresentada, bem como uma justificativa sobre o viés teórico com o qual a análise será desenvolvida neste capítulo.

\subsection{A Alternância Dativa: uma breve descrição}

A alternância dativa é caracterizada pela inversão da posição dos argumentos internos de um verbo que seleciona um argumento tema como seu objeto direto, e um argumento alvo, tradicionalmente marcado pela preposição dativa to no inglês. A construção análoga, que faz contraste com a construção dativa, por sua vez, apresenta o argumento alvo em forma acusativa - sem a presença de preposição - intervindo entre o verbo e o argumento tema, (cf. (93), abaixo). 
a. Peter sent a letter to Mary.

Peter enviou uma carta para Mary

'Peter enviou uma carta para Mary.'

b. Peter sent Mary aletter.

Peter enviou Mary uma carta

'Peter enviou uma carta para Mary.'

Pelo fato de Mary em (93) estar em uma posição mais próxima do verbo e não apresentar qualquer marca dativa, este fenômeno é conhecido como construção de objeto duplo. Ou seja, tanto Mary quanto a letter são considerados objetos do verbo, apesar do DP Mary não apresentar as características prototípicas de objeto direto (e.g., possuir a interpretação de tema). Ainda assim, Mary se comporta como um genuíno objeto direto em (94)b, quando em comparação com o objeto direto da construção dativa em (94)a, como é possível ver nos testes de passivização aplicados abaixo:

(94) a. John sent a letter to Mary.

$a^{\prime}$. A letter $r_{i}$ was sent $\left[t_{i}\right]$ to Mary.

a". *Mary ${ }_{i}$ was sent a letter to $\left[t_{i}\right]$.

b. John sent Mary a letter.

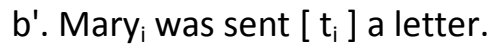

$b^{\prime}$. ?*A letter was sent Mary $\left[t_{i}\right]$.

(adaptado de LARSON, 1988, p. 363)

É importante notar que a terminologia adotada na literatura implica um viés transformacional para a análise dos dados acima. Quando se menciona alternância dativa, 
pressupõe-se que uma das construções "alterne", ou seja, uma das construções necessariamente deve ser vista como produto de operações sintáticas sobre a primeira. Esse tipo de ponto de vista surge desde Chomsky (1955), e inspirou a análise clássica de Larson (1988) para esses fenômenos no inglês. O trabalho de Larson será examinado na próxima seção, bem como as consequências da adoção do ponto de vista transformacional sobre as construções dativas e de objeto duplo.

4.1.1. VP shell: $a$ análise de Larson (1988)

Larson (1988) parte da observação de Barss e Lasnik (1986) sobre assimetrias em Construções com Duplo Objeto (DOCs), em especial no que diz respeito à relação de ccomando entre os argumentos internos do verbo.

O autor afirma que nas construções de objeto duplo em (95) (abaixo), o segundo argumento (tema) está no domínio do primeiro argumento (alvo), mas o contrário não é verdadeiro. Por conta dessa assimetria de domínios, temas nunca podem c-comandar o alvo nestas construções.

'Eu mostrei [Mary] [ela mesma].'

* I showed [herself] [Mary]. 
b. I gave [every worker $\mathrm{i}_{\mathrm{i}}$ [his $\mathrm{s}_{\mathrm{i}}$ paycheck].

(ligação de quantificador)

'Eu dei [cada trabalhador ${ }_{i}$ ] seu $_{i}$ contracheque].'

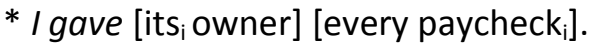

c. [Which $\operatorname{man}_{\mathrm{i}}$ ] did you send [his, paycheck]?

(cruzamento fraco)

'[Qual homemi] você enviou [seu contracheque]?'

* Whose ${ }_{\mathrm{i}}$ pay did you send $\mathrm{his}_{\mathrm{i}}$ mother?

'O pagamento de quem ${ }_{i}$ você enviou para a mãe dele $e_{i}$ ?'

d. Who did you give which paycheck?

(superioridade)

'(Para) quem você deu qual contracheque?'

*Which paycheck did you give who?

e. I showed each man the other's socks.

(cada... o outro)

'Eu mostrei cada homem as meias do outro.'

*I showed the other's friend each man.

'Eu mostrei o amigo do outro cada homem.'

f. I showed no one anything.

(itens de polaridade negativa)

'Eu mostrei ninguém nada.'

*I showed anyone nothing.

(adaptado de LARSON, 1988, pp. 336-337) 
A mesma assimetria aparece nas construções dativas, com a diferença que, neste caso, é o (PP) alvo que não pode c-comandar o (NP) tema:

(96)

*I presented/showed [herself] [to Mary].

b. I gave/sent every check $\mathrm{i}_{\mathrm{i}}$ to $\mathrm{its}_{\mathrm{i}}$ owner.

(ligação de quantificador)

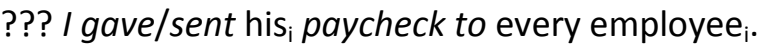

c. Which check $\mathrm{k}_{\mathrm{i}}$ did you send to its owner? ow

(cruzamento fraco)

*Which worker ${ }_{\mathrm{i}}$ did you send his $_{\mathrm{i}}$ check to?

d. Which check did you send to who?

(superioridade)

*Whom did you send which check to?

(*To whom did you send which check?)

e. I sent each boy to the other's parents.

(cada... o outro)

*I sent the other's check to each boy.

f. I sent no presents to any of the children. (itens de polaridade negativa)

* I sent any of the packages to none of the children.

(adaptado de LARSON, 1988, p.338) 
Como as estruturas propostas para essas construções na época não davam conta de contrair as relações corretas de c-comando entre os argumentos internos do verbo, Larson propõe a seguinte estrutura abaixo para explicar a assimetria observada nas construções dativas:

(97)

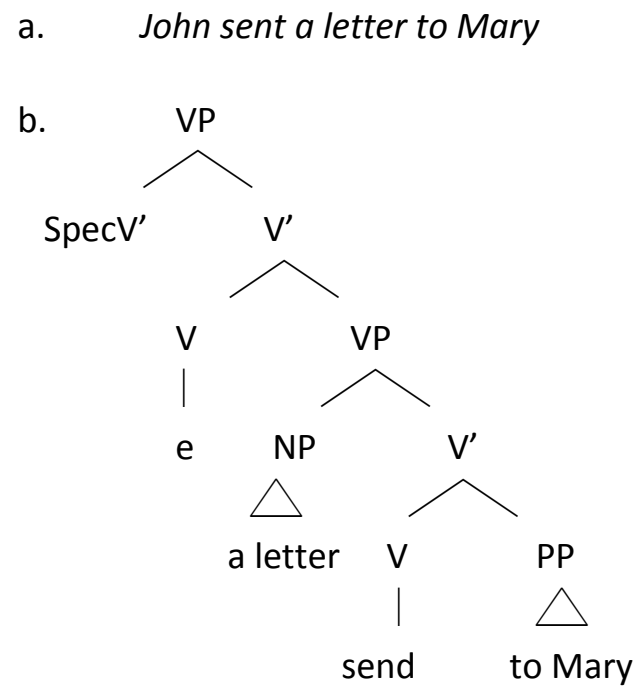

(LARSON, 1988, p. 348)

Com a estrutura em (97), Larson mantém os requerimentos de ramificação binária e ccomando assimétrico que os dados apontados por ele requerem. Forma-se uma espécie de predicado complexo entre send e to Mary, porém, como '*John a letter send to Mary' não é uma sentença bem-formada no inglês, o verbo não pode ficar na posição inferior, aparecendo à esquerda de $a$ letter. Assim, tem-se uma espécie de "concha", com dois VPs - um VP shell.

Ainda é possível afirmar que essa estrutura está de acordo com as observações de:

- Roberts (1985): $\vee$ deve ser núcleo de uma posição regida por Infl (para receber informações de tempo e concordância); 
- Stowell (1981), Travis (1985) e Koopman (1985): Caso do NP é atribuído sob regência, e a direção para o inglês é à direita (assim send pode atribuir caso acusativo para $a$ letter);

- Chomksy (1955/1975): Com o alçamento de V, o OD c-comanda OI, independente da estrutura do PP.

Para as construções de objeto duplo, Larson propõe que ocorra uma derivação semelhante às construções passivas. Como o argumento com o papel temático de alvo pode ser passivizado, é ele que ocupa a posição de argumento interno do VP. Assim como nas passivas, em que o elemento com o papel temático de sujeito é introduzido em uma posição de adjunto, o argumento tema nas construções de objeto duplo possui este status, sendo adjungido à V', a partir do que Larson chama de rebaixamento de argumento (92):

(98) "Rebaixamento" de Argumento:

Se $\alpha$ é um papel $\theta$ atribuído por $X^{i}$, então $\alpha$ pode ser atribuído (opcionalmente ou não) a um adjunto de $X^{i}$

A partir da operação de rebaixamento de argumento, observam-se os seguintes fatos; (i) o Caso do objeto indireto é absorvido, acarretando o apagamento (absorção) da preposição to; (ii) o papel temático atribuído ao sujeito de VP (argumento tema) é rebaixado, reduzindo tal posição ao status de não temática, já que é atribuído por $V^{\prime}$ (o equivalente a $X^{i}$ ), e pode, portanto, ser omitido, como um sujeito de passiva, por exemplo. O papel $\theta$ de tema, atribuído ao sujeito de VP, passa a ser atribuído em configuração de adjunção; (iii) pelo fato de o alvo estar sem Caso na posição mais baixa, a posição de sujeito de VP - vazia e não-temática, serve 
como local de movimento do argumento alvo (99); (iv) send é alçado para a posição de núcleo do $V$ mais alto, de onde atribui caso à direita para a posição de sujeito (100):

(99)

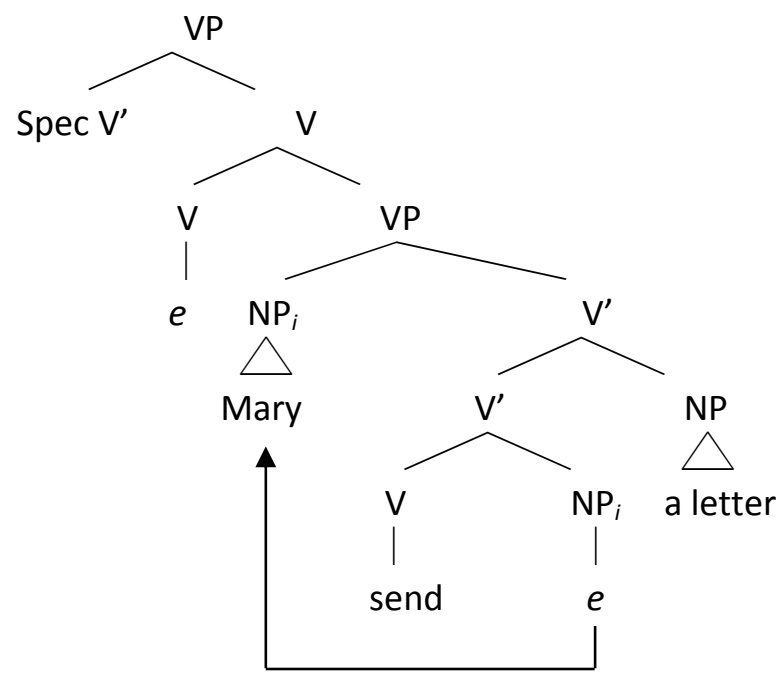

(LARSON, 1988, p. 353)

(100)

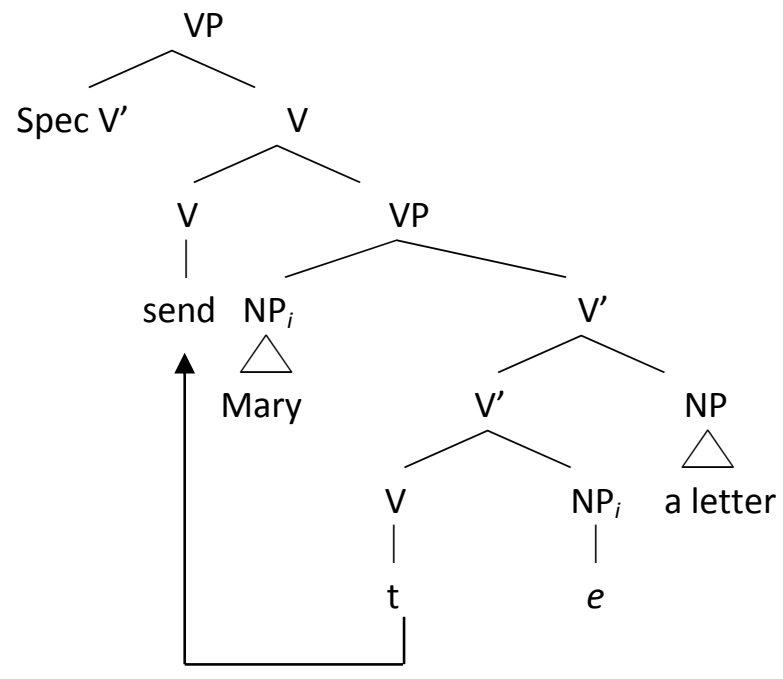

(LARSON, 1988, p. 353)

Apesar de a operação de deslocamento nas construções de objeto duplo serem análogas a operação presente na formação de passivas, as construções de objeto duplo seriam distintas pelo fato de que essa "passivização" da sua estrutura não requer a realização do morfema -en, assim como não é possível apagar o argumento interno da mesma maneira que é feito o apagamento do argumento externo das passivas. 
Para explicar a atribuição de Caso ao NP adjunto, Larson propõe que ocorra uma reanálise de $V^{\prime}$, que licencia a atribuição de caso ao argumento tema, e esse $V^{\prime}$ marcado é analisado como $\mathrm{V}$, já que tem um papel temático para descarregar. O NP a letter recebe caso na configuração canônica dos objetos diretos, regida pelo verbo, que, após movimento, ocupa posição superior na estrutura e c-comanda o NP em questão.

Alguns problemas importantes surgem quando essa proposta é levada em conta, apesar da cobertura empírica adequada. Esses problemas são de ordem de coerência interna do modelo. Quando a operação de reanálise e atribuição de papel temático ocorrem após o movimento do verbo, quebra-se uma regra fundamental dos níveis de representação gramatical do modelo de Regência e Ligação, no qual Larson se baseia: movimentos sintáticos só ocorrem em SS (estrutura superficial), um nível de representação no qual os filtros da teoria temática já foram aplicados. Logo, a atribuição de papel temático do argumento tema da construção de objeto duplo ocorre em um nível que não é responsável por checar a gramaticalidade desta atribuição.

Essa questão foi um dos vários desafios apresentados pelos autores em Teoria de Regência e Ligação que contribuíram para uma reavaliação, e, consequentemente, para o desenvolvimento do Programa Minimalista (CHOMSKY, 1995 et. seq.). Além disso, a noção de camadas de VP foi extremamente importante para o desenvolvimento das teorias sintáticas pós-Regência e Ligação, como a teoria de estrutura argumental de Hale \& Keyser (1993, 1998, 2002), e o próprio Minimalismo (CHOMSKY, 1995). A partir desses desenvolvimentos teóricos, outras análises foram propostas para o fenômeno da alternância dativa, dentre as quais duas correntes podem ser observadas: (i) a corrente derivacional e (ii) a corrente alternativa. A corrente derivacional postula duas estruturas diferentes, com uma estrutura básica, e outra estrutura derivada. Para os seguidores dessa proposta, a distinção de significados entre as construções da alternância dativa é nula, ou depende de fatores externos (e.g.: peso fonológico, fatores informacionais, cf. BRESNAN; NIKITINA, 2008). A corrente alternativa 
propõe que existam duas estruturas diferentes, de origens - e, consequentemente, de interpretações semânticas - diferentes. Os seguidores dessas propostas afirmam que a variação semântica das leituras entre as construções da alternância dativa justifica a proposta de mais de uma estrutura, com uma variação das relações entre os verbos e cada argumento (tema e alvo) para cada construção.

A proposta de Larson (1988) se encaixa no primeiro grupo. Como pode ser visto, existem problemas conceituais quando se observa mais a fundo o modelo teórico com o qual Larson trabalha. Na próxima seção, serão observadas duas análises da corrente alternativa, bem como seus argumentos para a rejeição da proposta de Larson.

\subsubsection{Pesetsky (1995) \& Harley (2002): interpretações diferentes, estruturas diferentes}

Pesetsky (1995) propõe que exista uma espécie de afixo vazio fonologicamente, o qual ele chama de $G$, e que explicaria uma série de alternâncias sintáticas e morfológicas no inglês. Para o autor, $G$ é uma espécie de preposição, e, no caso das construções de objeto duplo, assume a função de to. Para o autor, o verbo give faz uma seleção temática indireta do objeto da preposição to ou da preposição $G$, e uma seleção direta do DP que ocupa a posição de especificador. Tanto $G$ quanto to formam uma estrutura de tipo mini oração, com a diferença de que enquanto o complemento de $G$ recebe o papel de tema, o complemento de to deve ser alvo.

Para justificar as duas estruturas diferentes, o autor propõe que, nos casos de construções de objeto duplo, o verbo só pode selecionar argumentos que ele chama de "alvos 
verdadeiros". No caso das dativas, outros tipos de argumentos, como locativos, podem ser licenciados por to. Assim, o autor consegue explicar a motivação para que construções de objeto duplo sejam diferenciadas pela propriedade de transferência de posse (PINKER, 1989).

(101) Estrutura para as construções dativas (PESETSKY, 1995)

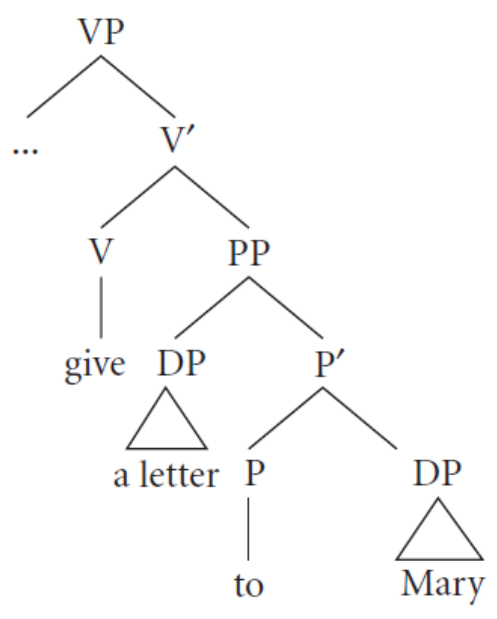

(102) Estrutura para as construções de objeto duplo (PESETSKY, 1995)

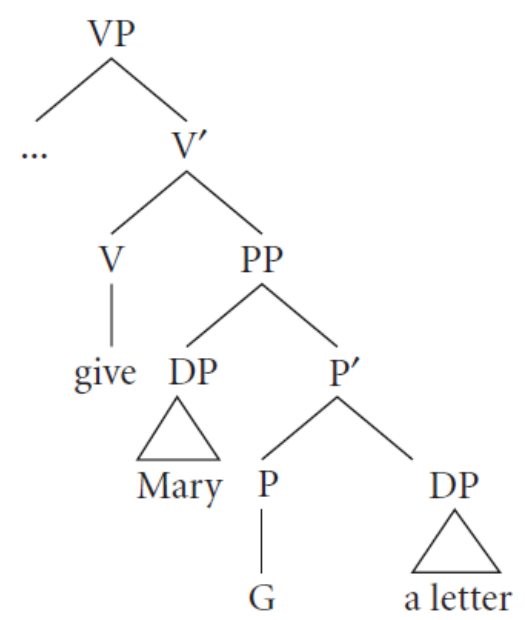

Para Pesetsky (op. cit.), as construções de objeto duplo poderiam apenas representar um subconjunto das interpretações semânticas que as construções dativas permitem, já que a 
interpretação locativa não é possível em construções de objeto duplo. Como é possível ver em (103), quando o tema é um local (Philadelphia), a construção de objeto duplo não é aceita ${ }^{43}$ :
a. The editor sent the article to Sue.
O editor enviou o artigo para Sue
'O editor enviou o artigo para Sue.'
b. The editor sent the article to Philadelphia.
O editor enviou o artigo para Philadelphia
'O editor enviou o artigo para Filadélfia.'
c. The editor sent Sue the article.
d. ??The editor sent Philadelphia the article.

(HARLEY, 2002, p. 35)

Harley (2002) segue a mesma linha de raciocínio de Pesetsky (1995) e mostra que as diferenças entre construções dativas e de duplo objeto possuem uma forte relação com interpretações de locação e posse.

A autora também mostra que existem variações de implicatura nos dados das duas construções; em (104)a é possível inferir que os alunos tenham, de fato, aprendido Francês, algo que não é obrigatório em (104)b. Neste caso, pode-se dizer que há uma transferência de posse metafórica, no sentido em que o conhecimento do professor passa para os alunos.

\footnotetext{
${ }^{43}$ Com exceção do caso em que Philadelphia seja interpretada como um grupo de pessoas que estão/residem neste local. Assim, se configuraria uma denotação animada para o alvo, e a sentença se tornaria aceitável.
} 
(104)

a. John taught the students French.

John ensinou os alunos francês

'John ensinou francês para os alunos.'

b. John taught French to the students.

John ensinou francês para os alunos

'John ensinou francês para os alunos.'

(HARLEY, 2002, p. 35)

Algo parecido acontece em (105), em que, na construção dativa (105)a, o bebê pode nem ter nascido, e ser apenas um plano dos pais. Quando a mesma sentença aparece na construção de objeto duplo, porém, só é possível interpretar como um suéter para um bebê já nascido.
a. I knitted this sweater for our baby.
Eu tricotei esse suéter para nosso bebê

'Eu tricotei esse suéter para nosso bebê.'

b. I knitted our baby this sweater.

Eu tricotei nosso bebê esse suéter

'Eu tricotei esse suéter para nosso bebê.'

(HARLEY, 2002, p. 36)

Com base nessas observações, Harley propõe que $G$ seja chamado de $P_{\text {HAVE, }}$ pois a autora acredita que este núcleo apresenta uma contribuição semântica maior do que apenas a presença de um "alvo verdadeiro", mas também seleciona um possuidor, o que traz uma relação obrigatória de transferência de posse entre o tema e o alvo. Para justificar a 
representação estrutural dessa relação, Harley (2002) aponta argumentos em favor de que to não seja o elemento exclusivo que garante a variedade de interpretações entre as dativas e as construções de objeto duplo, tal como Pesetsky (1995) propõe. A autora aponta que, ao contrário do que se deveria esperar, as construções com to não apresentam mais possibilidades de interpretação, já que existem leituras de objeto duplo que não aparecem nas construções dativas (cf. (104)-(105), acima), especialmente em casos de interpretação idiomática ((106)-(107)).

(106)
a. Mary gave John a kick.
Mary deu John um chute
'Mary deu um chute no John.'
b. *Mary gave a kick
to John.
Mary deu um chute
para John
c. Bill threw Mary a glance.
Bill lançou Mary um olhar
'Bill paquerou Mary'
d. *Bill threw a glance to Mary.
Bill lançou um olhar para Mary

(HARLEY, 2002, p. 39)

(107)

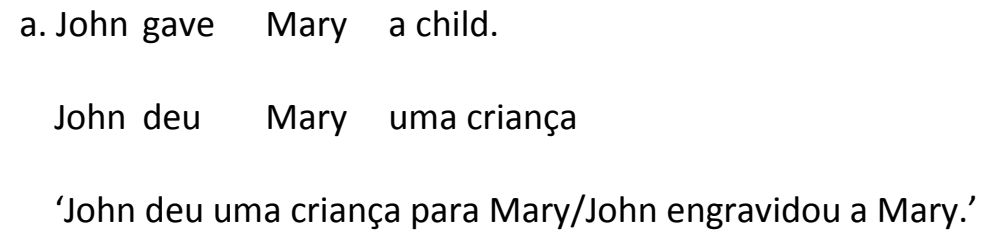




b. John gave a child to Mary.
John deu uma criança para Mary
'John deu uma criança para Mary.'

(HARLEY, 2002, p. 40)

Uma questão importante é levantada pela autora no que diz respeito a interpretações idiomáticas; enquanto Larson (1988) argumenta que a relação entre V e PP nas dativas é necessária para a interpretação idiomática de uma expressão como send _ to the showers (mandar __ pro chuveiro), Harley mostra que a relação é, de fato, entre o verbo e o argumento tema, e não entre o verbo e o adjunto alvo. Tal fato pode ser observado em (108):

(108)
a. Max gave his all to Linguistics.
Max deu seu tudo para Linguística
'Max deu tudo de si para a Linguística.'

b. Alice gives hell to anyone who uses her.
Alice dá inferno para qualquer um que use dela
training wheels.
treinamento rodas

'Alice inferniza qualquer um que use as suas rodinhas de bicicleta.' 


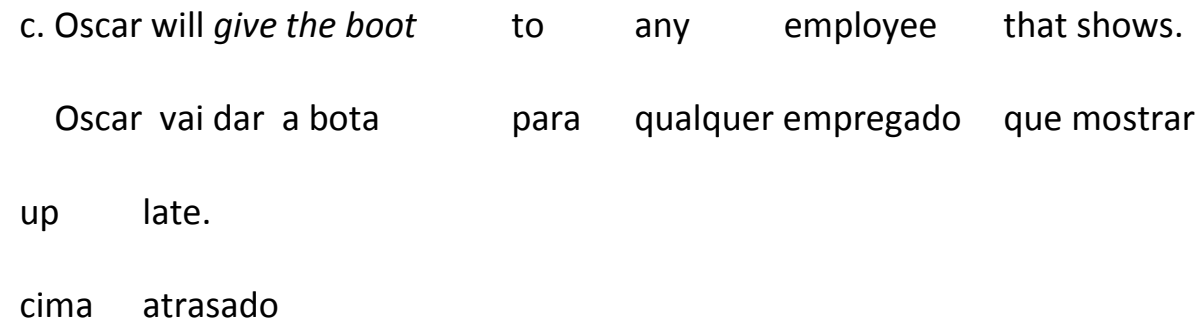

(HARLEY, 2002, p. 41)

Harley mostra que um contra-argumento poderia ser apontado por Larson (1988), que não considera que dados como os de (108) sejam idiomáticos, pelo fato de ser possível formar paráfrases dessas sentenças com o verbo get:

(109) a. Linguistics gets [my all].

b. I caught/got [hell] from Alice.

c. Peter got [the boot].

d. Geez, you get [the creeps] just looking at him. 
Richards (2001), porém, mostra que, caso isso fosse verdade, era de se esperar que o NP em questão em (111), abaixo, tivesse a mesma liberdade dos casos em (110):

(110) a. John is buying another white elephant.

b. White elephants have ruined many a company.

c. A white elephant's legacy is often financial ruin.

(111) a. *I was sorry to hear about the boot.

b. *The boot has ruined many an employee's Christmas.

c. ${ }^{*}$ The boot's legacy is often severe psychological problems.

(RICHARDS, 2001, p. 189)

Com os dados acima, Harley justifica a proposta de $\mathrm{P}_{\text {HAVE }}$ e a presença do alvo como especificador da preposição, ficando assim mais próximo do verbo, e justificando a leitura idiomática. Para o caso dos dados apontados por Larson (1988) nas construções dativas, a estrutura com $\mathrm{P}_{\mathrm{Loc}}$, que apresenta tema em [Spec, $\mathrm{P}_{\mathrm{Loc}}$, e alvo em [Comp, $\mathrm{P}_{\mathrm{Loc}}$ ] - ordem inversa em comparação a $P_{\text {HAVE }}$ - formaria uma relação idiomática no nível de $P^{\prime}$. Essa relação idiomática explicaria a impossibilidade de alternância nos moldes da proposta de Larson, favorecendo a escolha por um modelo mais próximo ao proposto por Pesetsky (1995).

Até aqui, as duas abordagens (derivacional e alternativa) foram apresentadas, e cada uma delas apresenta vantagens empíricas e teóricas para a análise das construções da alternância dativa. Nas próximas seções, os dados do PB serão observados, de modo a contribuir para a escolha pela abordagem mais apropriada para a explicação da ausência de alternância dativa no PB, bem como sua relação paramétrica com o Parâmetro da Realização Fonológica de Núcleos. 


\subsection{Fatores que bloqueiam a alternância dativa no PB: estendendo o alcance do Parâmetro de Realização Fonológica de Núcleos}

Nesta seção, o objetivo é apresentar argumentos que permitam uma aplicação do Parâmetro de Realização Fonológica de Núcleos aos dados de alternância dativa, de modo a explicar a ausência das construções de objeto duplo em PB como um caso de aplicação da operação de deslocamento compulsório (cf. cap. 3) em estruturas verbais, assim como acontece na variação entre nomes compostos do inglês e do PB. Partindo das propostas de Scher (1996) e Armelin (2011) para o PB, serão observadas as propriedades das dativas no PB, em favor de uma proposta de estrutura em comum entre as construções da alternância dativa do inglês e as dativas do PB. A partir dos dados do PB, será apontado que as construções dativas dessa língua apresentam as mesmas propriedades de transferência de posse, assim como também apresentam a possibilidade de formação idiomática.

A partir desses dados será proposta uma estrutura que capture as propriedades tanto da corrente alternativa quanto da corrente derivacional. Mantendo o modelo da Morfologia Distribuída como apoio para a análise proposta, será feita uma decomposição de traços inerentes nas preposições dos dados da alternância dativa, em comparação às preposições dos dados de compostos, que explicará o comportamento destes fenômenos em inglês e PB. 
4.2.1. Não existe alternância dativa no PB: Scher (1996) \& Armelin (2011)

Com base na observação do dialeto da região da Zona da Mata mineira, Scher (1996) e Armelin (2011) fazem importantes contribuições para a discussão da possibilidade de formação de construções de objeto duplo no PB. Scher (1996) mostra que os dados do dialeto mineiro (PBM), apesar de superficialmente semelhantes às construções de objeto duplo do inglês, não se comportam da mesma maneira quando se observa seus resultados frente aos diagnósticos sintáticos de restrição de verbos dativos românicos (112), de ausência da preposição na ordem dativa (113), e de passiva (114):
a. O João doou muito dinheiro ao orfanato.
b. João doou o orfanato muito dinheiro.
c. O Pedro distribuía seus agradecimentos aos amigos.
d. O Pedro distribuía os amigos seus agradecimentos.

(SCHER, 1996, p. 31)
e. John donated money
to charity.
John doou dinheiro
para caridade
'John doou dinheiro para a caridade.'
f. *John donated charity the money.
g. I distributed apples to the children
Eu distribuí maçãs para as crianças
'Eu distribuí maçãs para as crianças.'
h. ${ }^{*}$ I distributed the children apples.

(LARSON, 1988, p. 371, apud SCHER, 1996, p.30, nota 20) 
(113)
a. A Maria deu um livro aos/pros meninos.
b. Um livro foi dado aos/pros meninos.
c. ${ }^{*}$ Pros/aos meninos foi dado um livro.
d. *Os meninos foram dados um livro.

(114)
a. Eu entrego o livro o pai da Ana.
b. Ela deu o retrato o Pedro.
c. Mostra o carrinho os meninos!
d. Dá o recado o seu irmão.

(SCHER, 1996, p. 39)

Por conta dessas e outras assimetrias, a autora propõe que a alternância vista no PBM não seja considerada equivalente às construções de objeto duplo do inglês, mas que o fenômeno do PBM seja tratado como uma instância de topicalização do objeto indireto, enquanto a ausência da preposição seja consequência de um apagamento morfofonológico.

Armelin (2011) toma por base a análise feita por Scher (1996), e mantém a ideia de que não existam construções de objeto duplo no PB(M). Além de apoiar a hipótese de Scher (1996), a autora traz argumentos importantes em favor de uma análise para as construções dativas em que o argumento preposicionado não seja adicionado da mesma maneira que um aplicativo (PYLKÄNNEN, 2002), mas que possua uma relação de complemento estrutural do verbo $^{44}$. Para tal, a autora mostra que construções dativas com PP podem apresentar leituras idiomáticas (115), e a alteração do argumento tema não afeta a interpretação especial que a união entre o verbo e o PP gera (116):

\footnotetext{
${ }^{44}$ Apesar de afirmar que o argumento preposicionado seja adicionado da mesma maneira que um aplicativo, Armelin (2011) adota uma estrutura sintática diferente para a concatenação desse argumento. Enquanto Pylkännen (2002) propõe uma projeção funcional que licencia esse argumento, Armelin (2011) afirma que o argumento preposicionado seja gerado como núcleo+complemento.
} 
(115)
a. Entregar pra Deus.
b. Mandar/enviar pro espaço.
c. Chamar pra briga.
d. Dar no João.
e. Colocar na berlinda.

(ARMELIN, 2011, p. 125)

(116) Mandar o chefe pro espaço.
b. Mandar a pesquisa pro espaço.
c. Mandar a tristeza pro espaço.
d. Mandar o problema pro espaço.

(ARMELIN, 2011, p. 126)

Armelin também mostra que existem algumas questões no que diz respeito à semântica das preposições $a$ e para nos dados do PB e do PBM. Para a autora, a preposição para é ambígua entre a leitura de dativo e a leitura de beneficiário, enquanto a preposição $a$ permite apenas a leitura dativa:

a. O Pedro deu o livro [para a Maria] $\longrightarrow$ Interpretação default: alvo b. A Maria comprou um presente ao João, que estava fazendo aniversário, mas não pode ir à festa e pediu que o Pedro entregasse o presente ao João no lugar dela.

(ARMELIN, 2011, p. 104) 
Outra questão apontada pela autora é a de que apenas os verbos que aceitam $a$ como preposição (118) podem omiti-la em PBM (e, consequentemente, apresentar a sequência VNPNP), em contraste com verbos que só aceitam para (119):

(118) a. O pai deu o presente ao menino.

b. O pai deu o presente o menino.

(ARMELIN, 2011, p. 103)

(119) a. O pai consertou a bicicleta (para o/*ao) menino.

b. *O pai consertou a bicicleta o menino.

(adaptado de ARMELIN, 2011, p. 103)

Além dos fatos mencionados acima, a autora mostra que, apesar da ausência de alternância dativa, as construções dativas no PB (e no PBM) apresentam uma leitura de transferência de posse, cuja estrutura proposta pela autora é como em (120): 
(120)
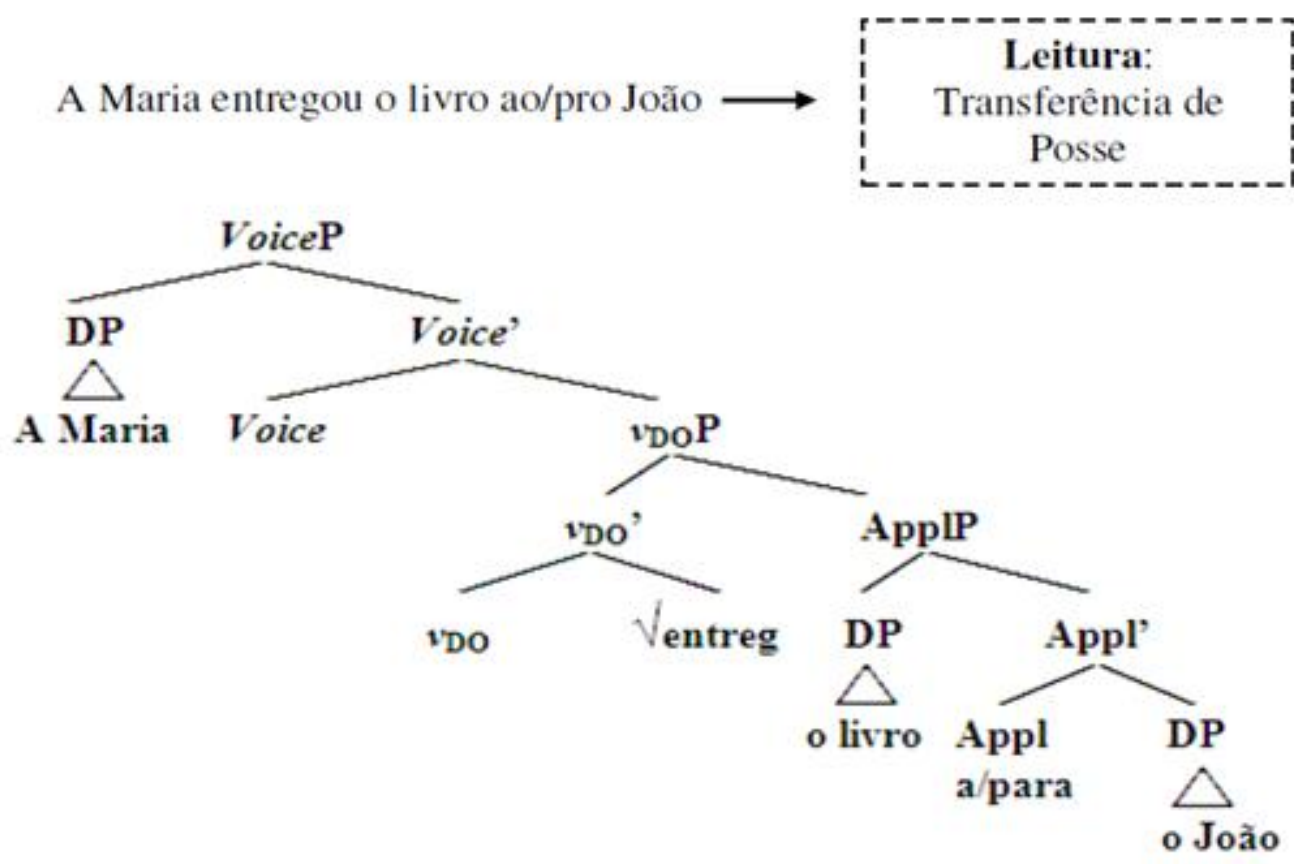

(ARMELIN, 2011, p. 139)

Retomando a proposta de Torres-Morais (2007) para o PE - em que se afirma a possibilidade de construções de objeto duplo nessa língua -, Armelin mostra que no PB a relação de transferência de posse aparece apenas nas construções em que para apresenta leitura dativa, e que a semântica da preposição $a$ em PE (121), difere do que é visto em PB (122):

(121) PE

a. A Maria fez um jantar aos convidados/fez-lhes um jantar.

b. A Maria fez um jantar para os convidados.

(TORRES-MORAIS, 2007, apud ARMELIN, 2011, p. 64) 
a. *A Maria fez o jantar ao amigo.

b. A Maria fez o jantar para o amigo.

$\longrightarrow A M B I G U I D A D E$

(ARMELIN, 2011, p. 65)

Nos casos acima citados, é possível ver que a preposição $a$ em PE apresenta a ambiguidade de leituras que são vistas no PB com a preposição para. Essa ambiguidade que para apresenta no PB e $a$ apresenta no PE é equivalente à distinção entre as preposições for e to no inglês. Porém, $a$ em PE também possui interpretação de origem, como a preposição de no PB:

a. PB

O Itaquerão roubou *ao/do Morumbi o título de sede da Copa de 2014.

b. PE

O Itaquerão roubou (?)do/ao Morumbi o título de sede da Copa de 2014.

Com esses fatos em mente, fica claro que a semântica das preposições envolvidas no fenômeno da alternância dativa é de suma importância. A diferença vista entre PB e PE advém dos diferentes conteúdos semânticos veiculados pelas suas preposições, e é importante apontar que, apesar de apresentar fenômenos sintáticos diferentes do PB no que diz respeito à ordem dos seus argumentos, o PE só pode formar as estruturas que Torres-Morais (2007) chama de construções de objeto duplo quando ocorre movimento/redobro de clíticos ou quando a preposição $a$ está presente. Ou seja, o fenômeno do PE apresentado por TorresMorais (2007) não aparenta ser um caso de alternância dativa no sentido tradicional da literatura sobre o fenômeno no inglês, mas uma variação devida às características polissêmicas da preposição $a$ em PE. De qualquer maneira, o foco da tese será mantido apenas nas 
estruturas do PB, deixando a discussão sobre a possibilidade de construções de objeto duplo no PE para trabalhos futuros.

Voltando para a questão da polissemia das preposições, é possível notar que existe uma diferença entre os traços de preposição que aparecem em PB e inglês no que diz respeito à semântica das construções dativas. Conforme mencionado, Harley (2002) afirma que a construção de objeto duplo é a responsável por carregar exclusivamente a leitura de transferência de posse, enquanto a construção dativa possui um caráter apenas locativo, sendo essa a sua principal característica.

A partir das observações de Armelin (2011) sobre a polissemia que as estruturas com para apresentam no PB, Barbosa \& Armelin (2012) apresentam a seguinte tabela sobre os fatos de inglês, PB e PBM:

(124) Tabela 4: Relação ordem de argumentos / presença de preposição em inglês, PB, e PBM

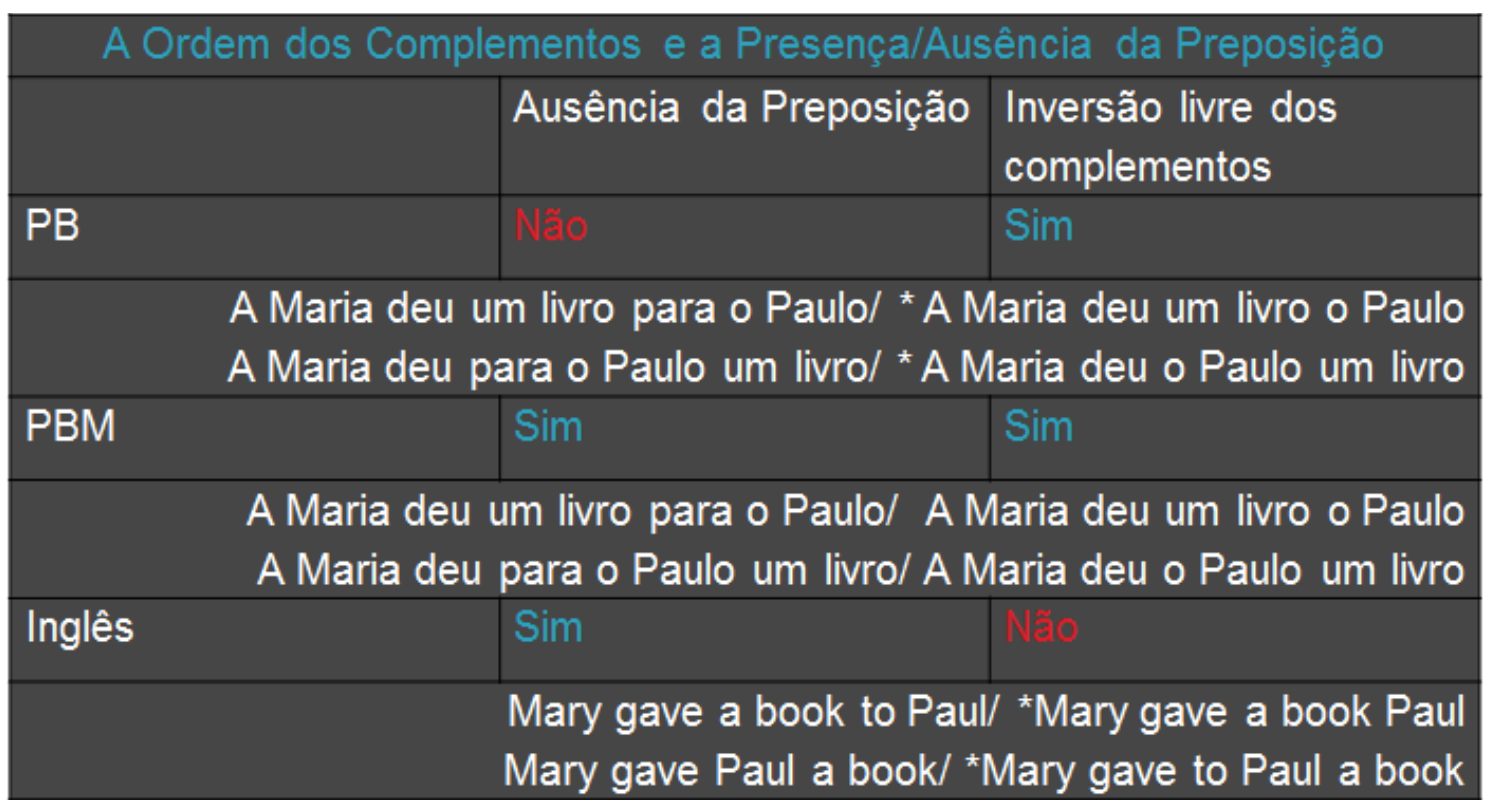

(BARBOSA; ARMELIN, 2012) ${ }^{45}$

\footnotetext{
${ }^{45}$ É importante notar que, nos casos em que o NP apresenta conteúdo fonológico "pesado", ocorre um deslocamento obrigatório do complemento, chamado de heavy NP shift (cf. (ii), abaixo):
} 
Quando a impossibilidade da sequência * Mary gave to Paul a book é levada em consideração, fica claro que a semântica da preposição to apresenta um papel muito mais forte do que para em PB, e que a liberdade de ordem no PB é um fenômeno completamente diferente da alternância dativa presente no inglês, assim como Scher (1996) e Armelin (2011) advogam. Na próxima seção, será proposta uma análise que explique a relação entre a impossibilidade de formação de construções de objeto duplo no PB e o PRNF, buscando explicar, a partir das relações dos traços dos compostos e dos dados da alternância dativa as questões sobre (i) a semântica das preposições, (ii) da semântica de transferência de posse nas dativas do PB (iii) as possibilidades idiomáticas na alternância dativa e (iv) as assimetrias apontadas por Barss \& Lasnik (1986).

\subsection{O Parâmetro de Realização de Núcleos Funcionais e a alternância dativa: uma proposta} de decomposição de traços

\subsubsection{Preposições ambíguas e a decomposição de $F$}

Conforme mostrado na seção anterior, as construções dativas do PB apresentam três interpretações possíveis: (i) uma leitura locativa, (ii) uma leitura de transferência de posse - as duas leituras que são utilizadas para apontar a distinção semântica entre as construções dativas e as construções de objeto duplo - e (iii) uma leitura de beneficiário, na qual a preposição para apresenta a semântica semelhante a for no inglês. Convém notar que, assim

(i) *John gave to Paul a book.

(ii) John gave to Paul a book about the rainforest. 
como no caso dos compostos no $\mathrm{PB}$, a agramaticalidade da construção de objeto duplo não acarreta a impossibilidade de apresentar uma leitura semântica que se assemelhe aos correlatos sintáticos vistos como exclusivos de línguas como o inglês. Assim como discutido no capítulo anterior, não seria possível continuar a discussão dos assuntos aqui abordados caso fosse mantida a enganosa concepção de que "se não existe determinada estrutura, não existe determinada leitura" ${ }^{46}$, pois essa visão impede que as variações translinguísticas sejam observadas como diferenças estruturais, ao invés de meras restrições no que uma língua é capaz de expressar. Por isso, a premissa central da análise desenvolvida neste capítulo será a mesma da análise para os compostos em PB e inglês: existe apenas uma estrutura para a alternância dativa, e a distinção de sua ordem se dá em operações de linearização, no caminho para PF.

Um ponto de vista que propõe uma estrutura única para essas construções vai de encontro às análises até aqui apresentadas para a alternância dativa, já que, ao longo do curso da evolução das discussões acerca do tema na literatura, sempre foi proposto que existissem duas estruturas sintáticas distintas para cada ordem dos argumentos dos verbos dativos, com o debate se constituindo sempre em torno de duas alternativas: (i) uma abordagem em que operações transformam uma construção em outra com os instrumentos disponíveis pelo sistema computacional - a abordagem derivacional, ou (ii) uma abordagem em que existam duas estruturas distintas para as dativas e as construções de objeto duplo - a abordagem alternativa.

Para explicar essa ruptura com a tradição das abordagens sobre o fenômeno da alternância dativa, a proposta teórica da Morfologia Distribuída aparece novamente como

\footnotetext{
${ }^{46}$ É importante notar que a análise proposta mantém, de fato, duas estruturas sintáticas para as construções dativas e as construções de objeto duplo. A diferença entre a análise aqui proposta e as demais é que a variação entre uma estrutura e outra se dá em PF, ao invés de LF. Assim, é explicado o porquê de construções de objeto duplo não estarem presentes em PB - apesar de a leitura de transferência de posse ser possível em dativas nessa língua - por meio de uma restrição paramétrica mais abrangente e que se justifica apenas por meios formais (estruturais), e não por distinções semânticas vagas e contestáveis.
} 
ponto de partida para explicar certas restrições e propriedades. Em primeiro lugar, o fato da ambiguidade das preposições em PB deve ser analisado. Conforme mostrado na seção anterior, a preposição $a$ em PB e PE apresentam leituras variadas, em que $a$, no PE, aparece em alguns contextos ocupados por de no PB. Da mesma maneira, para permite que uma leitura de beneficiário seja observada em alguns casos de construções dativas em PB. Assim como para é ambíguo nas dativas do $\mathrm{PB}$, de nos compostos do $\mathrm{PB}$ pode apresentar ambiguidade entre leituras de posse (125)a e origem (125)b:

(125) a. bolo de cenoura, casa de madeira, parque de diversões...

b. garota de Londres, aluno da USP, peixe de água doce...

Apesar de notar que essas leituras são passíveis de um refinamento semântico mais detalhado (é possível dizer que fubá e madeira são materiais de bolo e casa, respectivamente, ou que diversões não é algo que o parque possua, mas proporcione, ou que a garota não veio de Ipanema, mas frequentava aquela praia, etc.), a ideia geral a ser adotada aqui é a de que essas relações vagas e ambíguas dos compostos (OLSEN, 2008) são produto de traços semânticos mais básicos, o que permite a variedade de significados e interpretações nestas construções, aliadas ao conhecimento de mundo de cada falante. No caso do inglês, é possível observar que existe uma ambiguidade entre of e with nos contextos possessivos, e entre of e from nos contextos de origem/locativos (126):

a. carrot cake $=$ a cake made of $/$ with carrots

'bolo de cenoura $=$ um bolo feito de/com cenouras'

b. wooden house $=$ a house made of/with wood

'casa de madeira = uma casa feita de/com madeira' 
c. amusement park = a park with amusing rides...

'parque de diversões = um parque com brinquedos divertidos'

d. London girl = garota (que está sempre/vem) em/de Londres

e. USP student $=$ aluno (que estuda/vem) na/da USP

f. freshwater fish = peixe (que vive/é encontrado) em água doce

Com base nesses dados, serão utilizados aqui os traços [posse] e [locativo] como componentes dos nomes compostos, seja no inglês ou no PB. A distinção de aplicação desses traços deriva a diferença semântico-sintática vista entre as línguas em questão. A postulação desses traços é desejável, já que a estrutura a ser proposta para a alternância dativa apresenta variação em suas leituras exatamente em torno das questões de transferência de posse (compatível com o traço [posse]) e indicação de um ponto final de deslocamento (compatível com o traço [locativo]).

Decompondo os traços dessas preposições com relação ao que é visto no inglês e em PB, é proposta a seguinte distinção: quando a projeção $F$ é categorizada por $v$, a estrutura é interpretada como uma construção verbal; quando categorizada por $n$, é interpretada como uma expressão nominal. É devido ao categorizador que os traços [posse] e [locativo] apresentam realizações fonológicas distintas em cada caso. No caso do inglês, a realização desses traços se dá conforme apresentado na tabela 5, abaixo: 
inglês

\begin{tabular}{|c|c|c|c|}
\hline INGLÊS & & & \\
\hline [causa] & v & $n$ & $n$ \\
\hline+ & [causa] & [entidade] & [entidade] \\
\hline F & + & + & + \\
\hline [posse] $(\varnothing)$ & [locativo] (to) & [locativo] $(\varnothing)$ & [locativo] (from) \\
\hline Objeto duplo & [posse] ('s) & [of) \\
\hline
\end{tabular}

Em inglês, construções de objeto duplo apresentam o traço [posse], enquanto dativas apresentam o traço [locativo]. Para os compostos, ambos os traços são permitidos; porém, a realização do traço [posse] pode ser evidenciada pela marca de genitivo ' $s$. Nos compostos preposicionados, a preposição from realiza o traço [locativo] enquanto of é o correspondente fonológico para o traço de $[p o s s e]^{48}$. No caso das construções dativas, to é a realização fonológica de [locativo], enquanto nas construções de objeto duplo, o traço [posse] não possui realização fonológica correspondente $(\varnothing)$.

\footnotetext{
${ }^{47}$ Apesar de representar a função de realização de [posse] nos compostos do inglês, a marca 's não é realizada como núcleo de $F$, pois não é fonologicamente autônoma para ocupar tal posição. Seu estatuto morfofonológico distinto explicaria o comportamento sintático diferente dos compostos tradicionais do inglês.

${ }^{48}$ Conforme será mostrado na seção 4.3.1.1., é possível, em alguns casos, que haja uma ambiguidade de interpretação entre uma leitura de transferência de posse e uma leitura de movimento. A solução mais simples seria dizer que tanto o traço [locativo] quanto o traço [posse] estão presentes, e a interpretação é dada pelo contexto pragmático. Nos casos em que tal competição ocorresse, o traço mais relevante para a interpretação semântica se sobreporia, permitindo a inserção do conteúdo fonológico mais apropriado para sua interpretação. Com base nos dados de Bresnan \& Nikitina (2008), será proposto que apenas um traço apareça por estrutura, e que a ambiguidade seja explicada de outra maneira. Essa questão será retomada na seção 4.4 .
} 
Já no caso do $\mathrm{PB}$, não existem preposições exclusivas para a denotação do traço [locativo] ou para a denotação do traço [posse], conforme se pode observar na tabela 6, abaixo:

(128) Tabela 6: Possibilidades de combinação dos traços [posse] e [locativo] em PB

\section{PB/PBM}

\begin{tabular}{|c|c|c|c|}
\hline v & V & $\mathrm{n}$ & $n$ \\
\hline [causa] & [causa] & [entidade] & [entidade] \\
\hline+ & + & + & + \\
\hline \multirow[t]{2}{*}{$\mathrm{F}$} & $F$ & $\mathrm{~F}$ & $\mathrm{~F}$ \\
\hline & $\begin{array}{c}\text { [locativo] (a/para) } \\
\text { [posse] (a/para) }\end{array}$ & & $\begin{array}{c}\text { [locativo] (de) } \\
\text { [posse] (de) }\end{array}$ \\
\hline$=$ & $=$ & $=$ & $=$ \\
\hline Impossível & Dativo & Impossível & $\begin{array}{c}\text { Compostos } \\
\text { preposicionados }\end{array}$ \\
\hline
\end{tabular}

Como nem construções de objeto duplo nem compostos N+N não são possíveis em PB, é postulado que os traços [posse] e [locativo] só possam aparecer em construções nas quais a preposição é sempre realizada. Seja qual for o traço relevante, a constituição dos itens de vocabulário do PB só apresenta uma opção para os compostos (de), e aceita tanto a quanto para nas duas interpretações possíveis para as construções dativas (cf. Tabela 4, acima).

Conforme o que foi apresentado nos capítulos 1 e 2, a relação tipológica entre a realização do traço de [modo] entre línguas românicas e germânicas feita por Talmy (2000) aparenta ser crucial para a explicação de determinadas questões relacionadas ao Parâmetro de Composição (Snyder 1995, 2001). Por conta disso, é interessante observar que a questão da incorporação do traço [modo] (ou [manner]) também é apontada nos trabalhos que lidam com a alternância dativa. Seguindo o que é apresentado pela literatura sobre a alternância dativa, as construções de objeto duplo não apresentam leitura de movimento (Pesetsky 1995), nem permitem serem formadas a partir de verbos que denotem determinados modos de 
movimento, ou verbos com modo de fala (LEVIN, 1993, PINKER, 1989, KRIFKA, 2001). A possibilidade dessas instâncias de [modo] ocorrendo no verbo apenas nas construções de objeto duplo - mas não nas dativas - é um problema para a proposta feita até aqui. Se o traço de [modo] pode ocorrer no verbo em inglês, qual seria a restrição de ocorrência em construções dativas dessa língua?

Da mesma maneira em que essa aparente assimetria de [modo] pode ser apontada, os traços [locativo] e [posse] também apresentam problemas, especialmente quando são comparados PB e inglês. Para que a tabela 3 (sobre o inglês, acima) estabelecesse um paralelo desejável com a tabela 4 (sobre o PB, acima), era de se esperar a presença tanto de [posse] quanto de [locativo] nas construções de objeto duplo e nas construções dativas, já que a restrição maior quanto à formação de construções é em PB, e, nas variedades em que elas são permitidas (dativas e compostos preposicionados), os traços [posse] e [locativo] estão presentes sem qualquer restrição.

Em favor de uma uniformidade dos dados, o trabalho de Bresnan \& Nikitina (2008) será levado em conta na seção a seguir, de maneira a explicar os problemas apontados acima.

4.3.2. Argumentos em favor de uma análise unificadora para a alternância dativa: Bresnan \& Nikitina (2008)

Nesta seção, o objetivo é apontar argumentos recentes dentro da teoria gerativa, de modo a mostrar que a discussão da alternância dativa caminha na direção das análises derivacionais (e.g., LARSON, 1988), em detrimento de análises alternativas (com duas 
estruturas não relacionadas, e.g.. PESETSKY, 1995, HARLEY, 2002). O trabalho de Bresnan \& Nikitina (2008) aponta evidências empíricas interessantes nesse sentido. A partir das evidências empíricas apresentadas nesta seção, será proposta uma estrutura única para as construções da alternância dativa que explique os problemas de c-comando da quantificação e os argumentos de variação paramétrica desenvolvidos nesta tese.

Adotando os pressupostos da Teoria da Otimidade (T.O.), Bresnan \& Nikitina (2008) vão em direção oposta às análises gerativistas, e propõem que a alternância dativa seja considerada um fenômeno que depende de restrições baseadas em questões informacionais: (i) a natureza discursiva dos argumentos do verbo, (ii) a relação entre informação nova versus informação dada, ou (iii) a restrição de ordem por proeminência (e.g., pronomes precedem NPs, pois são mais proeminentes no discurso).

Os dados relevantes para as autoras são os apresentados em (129)-(131), os quais sempre foram levados em consideração ao longo das discussões acerca das construções de objeto duplo. De acordo com a literatura anterior sobre esses dados, foi sempre dito que verbos de aplicação contínua de força com movimento acompanhado ${ }^{49}$ (129) e verbos com

${ }^{49} \mathrm{O}$ contraste a ser feito é entre (i) verbos de aplicação instantânea de força causando algum movimento de projétil e (ii) verbos de aplicação contínua de força causando algum movimento acompanhado (PINKER, 1989); apenas os verbos em (i) permitem a construção de objeto duplo, enquanto os verbos em (ii) só aceitam a construção dativa:

(i)

$$
\begin{aligned}
& \text { Lafleur throws/ tosses/ flips/ slaps/ kicks/ } \\
& \text { Lafleur joga/ lança/ joga virando de ponta cabeça/ dá um tapa/ chuta/ } \\
& \text { pokes/ flings/ blasts him the puck; } \\
& \text { cutuca/ arremessa/ passa com toda a força (lit. explode) ele o disco; } \\
& \text { he shoots, he scores! } \\
& \text { ele dá o tiro, ele marca! }
\end{aligned}
$$

(cf. Lafleur throws/tosses/flips/slaps/kicks/pokes/flings/blasts the puck to him; he shoots, he scores!)

(ii) *Icarried/ pulled/pushed/ schlepped/ lifted/

Eu carreguei/ puxei/ empurrei/ carreguei com dificuldade/ ergui/

lowered/ hauled John the box.

abaixei/ arrastei John a caixa

(cf. I carried/pulled/pushed/schlepped/lifted/lowered/hauled the box to John.) 
modo de fala ${ }^{50}(130)$ ocorrem apenas em construções de objeto duplo, mas não em suas variantes dativas, assim como se diz impossível a alternância give $\mathrm{NP}_{2} \mathrm{NP}_{1}$ para give $\mathrm{NP}_{1}$ to $\mathrm{NP}_{2}$ quando as sentenças possuem leitura idiomática (131):

a.I threw the box to John. I threw John the box.

Eu arremessei a caixa para John

"Eu dei a caixa para John arremessando-a."

b. I lowered the box to John. $f *$ Ilowered John the box.

Eu abaixei a caixa para John

"Eu dei a caixa para John abaixando-a/levando-a para baixo."

(BRESNAN; NIKITINA, 2008, p.3)

(130)

a. Ann faxed the news to Beth. $\sim$ Ann faxed Beth the news

Ann fax(passado) as notícias para Beth

"Ann mandou as notícias para Beth por fax."

b. Ann yelled the news to Beth. * $^{*}$ Ann yelled Beth the news.

Ann gritou as notícias para Beth

"Ann deu as notícias para Beth gritando."

(BRESNAN; NIKITINA, 2008, p.3)

\footnotetext{
${ }^{50}$ No caso dos verbos de modo de fala, o contraste relevante é o seguinte:

(i) Susan

cabled/ emailed/faxed/phoned/telegraphed/... Rachel the

Susan (mandou por) cabo/ e-mail/ fax/telefone/telegrama/... Rachel as

news.

notícias

(cf. Susan cabled/emailed/faxed/phoned/telegraphed/... the news to Rachel.)

(ii) *Susan whispered/yelled/mumbled/barked/muttered... Rachel the news.

Susan sussurrou/gritou/ resmungou/latiu/ murmurou... Rachel as notícias

(cf. Susan whispered/yelled/mumbled/barked/muttered... the news to

Rachel.)
} 
(131)

The lighting here gives me a headache.

A iluminação aqui dá $\operatorname{mim}$ uma dor-de-cabeça

"A iluminação aqui me dá dor-de-cabeça"

$\uparrow^{*}$ The lighting here gives a headache to me.

(BRESNAN; NIKITINA, 2008, p.3)

Apesar dos dados acima serem utilizados para apontar características exclusivas das construções de objeto duplo, Bresnan \& Nikitina (2008) mostram que, ao contrário do que sempre foi afirmado a partir das intuições sobre os dados de alternância dativa de (129)-(131) acima, existem, em dados na internet, várias instâncias de realização tanto de verbos de aplicação contínua de força com movimento acompanhado (132), como de verbos com modo de fala (133), bem como possibilidade de alternância idiomática de give $\mathrm{NP}_{2} \mathrm{NP}_{1}$ para give $\mathrm{NP}_{1}$ to $\mathrm{NP}_{2}(134)^{51}$ :

(132) VERBOS DE APLICAÇÃO CONTÍNUA DE FORÇA

a. Karen spoke with Gretchen about the procedure for registering a complaint, and hand-carried her a form, but Gretchen never completed it. $\underline{\text { mão-carregou ela um formulário }}$

b. As Player A pushed him the chips, all hell broke loose at the table. empurrou ele as fichas

c. Therefore, when he got to purgatory, Buddha lowered him the silver thread abaixou ele a teia prateada of a spider as his last chance for salvation.

\footnotetext{
${ }^{51}$ Dada a natureza peculiar da interpretação dessas sentenças, serão destacados com glosa apenas os trechos relevantes dos dados em questão.
} 
d. Nothing like heart burn food. "I have the tums." Nick joked. He pulled himself

puxou ele mesmo

a steaming piece of the pie. "Thanks for being here."

$\underline{\text { um fumegante pedaço de a torta }}$

e. "Well... it started like this..." Shinbo explained while Sumomo dragged him a

arrastou ele uma

can of beer and opened it for him, "We were having dinner together and..."

$\underline{\text { lata de cerveja }}$

(BRESNAN; NIKITINA, 2008, p.4)

(133) VERBOS DE MODO DE FALA

a. Shooting the Urasian a surprised look, she muttered him a hurried

resmungou ele uma apressada

apology as well before skirting down the hall.

desculpa

b. "Hi baby", Wade says as he stretches. You just mumble him an answer. You

$\underline{\text { balbuciar ele uma resposta }}$

were comfy on that soft leather couch. Besides...

c. The shepherd-dogs, guardians of the flocks, barked him a welcome,

latiu ele uma boa-vinda

and the sheep bleated and the lambs pattered round him.

d. I think he was poking fun at the charges that Blackmore has been making that he chronically forgets words - he went over to Jon Lord during 'Smoke' and seemed to be getting Jon to yell him the words!!

gritar ele as palavras 
e. I still can't forget their mockery and laughter when they heard my question.

Finally a kind few (three to be exact) came forward and whispered me the

sussurrar me a

answer.

$\underline{\text { Resposta }}$

(BRESNAN; NIKITINA, 2008, p.5)

(134)

EXPRESSÕES IDIOMÁTICAS "EXCLUSIVAS DE DOUBLE OBJECT"

a. GIVE A HEADACHE TO (DAR UMA DOR-DE-CABEÇA)

(i) From the heads, offal and the accumulation of fishy, slimy matter, a stench or smell is diffused over the ship that would

give a headache to the most athletic constitution.

dar uma dor-de-cabeça para a mais atlética constituição

(ii) Design? Well, unless you take pride in

giving a headache to your visitors

dar uma dor-de-cabeça para seus visitantes

with a flashing background?

b. GIVE A PUNCH TO (DAR UM SOCO)

(i) When the corpse was bloodless, he got up and grinned to Ethanvampire, oh so happy. "Oh yesssss!". He gave [a punch tol ${ }^{52}$ his

deu um soco para seu

old mate. "Let's find a bar, Ethan."...

velho companheiro

52 Parte do dado deduzida a partir dos dados restantes, já que não aparece no texto original provavelmente, por um erro de digitação. 
(ii) "Well, mate, you asked for it." - And he gave a punch to the guy

deu um soco para o cara

in the middle of his face, splotching...

(iii) All three headed toward Mulan. She dropped kicked the first. Next she gave a punch to the second man. He blocked so she grabbed his deu um soco para o segundo homem arm and flipped him...

c. GIVE A BREAK TO (DEIXAR EM PAZ)

(i) PUC gives a break to big users of energy dá uma folga para grandes usuários de energia

(ii) "Why can't we give a break to the people who organise them dar uma folga para as pessoas que organizam eles [the matches]?"

(iii) Give a break to the overburdened who have Dê uma folga para os sobrecarregados quem tem no place to rest.

$\underline{\text { nenhum lugar para descansar }}$

d. GIVE A HARD TIME TO (DAR TRABALHO)

(i) The silly clowns sometimes give a hard time to the emperor.

dão um duro tempo para o imperador

(ii) The Necromancer has a wide area of spells he can use to either stay out of trouble or give a hard time to his opponents.

dar um duro tempo para seus oponentes 
(iii) Those who have come before traditionally give a hard time

dão um duro tempo

to those who have just come.

para aqueles quem tem apenas chegado

e. GIVE GRIEF TO (DAR UMA BRONCA)

(i) Still, I took it back today and gave some grief to the assistant

dei algum pesar para a assitente

and came out with a better scanner than I had paid for on Tuesday.

(ii) He gave grief to those taking their time near the rear, deu pesar para aqueles tomando seus tempos perto o fundo

I remember watching him from outside the bus while we stood on the yellow footprints.

(BRESNAN; NIKITINA, 2008, pp. 5-7)

Tomando essa base empírica em favor da análise aqui proposta, parece que os argumentos em favor de uma análise alternativa (e.g., PESETSKY, 1995, HARLEY, 2002) deixam de ser relevantes, já que a exclusividade de ocorrência das construções de objeto duplo como um tipo de construção distinta estruturalmente e semanticamente da construção dativa não se sustenta como sempre foi proposto. Apesar disso, se a construção de objeto duplo não é tão especial quanto aparentava ser, o que impede a ocorrência deste fenômeno em línguas como o PB? 
Seguindo as propostas de Bresnan \& Nikitina (2008), as análises alternativas para a alternância dativa devem ser descartadas, em favor de análises derivacionais para o fenômeno. Com um novo ponto de vista delineado sobre as propriedades das construções que participam da alternância dativa, apresenta-se o instrumental teórico e empírico adequado para argumentar em favor de uma análise para essas construções a partir do Parâmetro de Realização de Núcleos Funcionais. Essa análise será desenvolvida na seção a seguir.

\subsection{Aplicando o Parâmetro de Realização de Núcleos Funcionais à alternância dativa: resultados e consequências}

Até aqui, foi mostrado que as construções dativas do PB apresentam as mesmas leituras que caracterizam as construções de objeto duplo como especiais no inglês. Ao que tudo indica, essas leituras "especiais" e as interpretações que são consideradas impossíveis nas construções de objeto duplo aparecem também em formas dativas, conforme apresentado pelos dados de Bresnan \& Nikitina (2008) na seção anterior. Portanto, seria coerente adotar uma proposta de análise derivacional para as construções da alternância dativa.

$\mathrm{Na}$ análise definida abaixo existe, contudo, uma pequena mudança em relação aos trabalhos que defendem a construção de objeto duplo como originada da construção dativa. A ideia a ser explorada nesta tese é a de que a estrutura da construção dativa é a única estrutura disponível em LF. Ou seja, a semântica das construções dativas e de objeto duplo é, essencialmente, a mesma. A diferença entre a construção de objeto duplo e a construção 
dativa se dá na morfologia, pós-spell-out. O que determina se a estrutura será realizada como uma construção dativa é a presença de [locativo], enquanto a presença de [posse] garante a interpretação como uma construção de objeto duplo.

Com essa proposta, a estrutura sintática superficial da construção - ou seja, a forma resultante em PF - é determinada pelas propriedades semânticas presentes na estrutura comum às duas interpretações em LF, ao contrário das análises tradicionais, nas quais a interpretação semântica é o produto da estrutura sintática, que relaciona cada interpretação a uma estrutura diferente. Se a estrutura em LF é a mesma para as duas construções no que diz respeito à ordem dos argumentos, o que determina a estrutura de superfície em PF é a realização fonológica dos traços [posse] e [locativo] em PF, dependendo do conjunto de itens de vocabulário disponíveis para inserção na língua. Como é possível observar na tabela 5, repetida abaixo em (135), a realização de [posse] e [locativo] em estruturas c-comandadas por $v$ possuem apenas um correspondente para a realização de cada um dos traços em questão.

(135) Tabela 5: Possibilidades de combinação dos traços [posse] e [locativo] em inglês

\section{INGLÊS}

\begin{tabular}{|c|c|c|c|}
\hline v & v & $n$ & $\mathrm{n}$ \\
\hline [causa] & [causa] & [entidade] & [entidade] \\
\hline+ & + & + & + \\
\hline $\mathrm{F}$ & $\mathrm{F}$ & $\mathrm{F}$ & $\mathrm{F}$ \\
\hline [posse] $(\varnothing)$ & [locativo] (to) & $\begin{array}{c}\text { [locativo] }(\varnothing) \\
\text { [posse] ('s) }\end{array}$ & $\begin{array}{c}\text { [locativo] (from) } \\
\text { [posse] (of) }\end{array}$ \\
\hline$=$ & $=$ & $=$ & $=$ \\
\hline Objeto duplo & Dativo & "Compound" & $\begin{array}{c}\text { Compostos } \\
\text { preposicionados }\end{array}$ \\
\hline
\end{tabular}


De acordo com o que é proposto, não há conteúdo fonológico a ser inserido para o traço [posse]. Se o Parâmetro de Realização Fonológica de Núcleos - repetido em (136), abaixo - for adotado para a alternância dativa da mesma forma que nos compostos nominais, as estruturas sobre as quais PF opera são as seguintes:

Parâmetro de Realização Fonológica de Núcleos

Uma língua permite que uma projeção funcional $F$ omita o conteúdo fonológico de seu núcleo em PF.

$$
\begin{aligned}
& \{\operatorname{sim}\}=\text { inglês } \\
& \{\text { não }\}=\text { PB }
\end{aligned}
$$

(137)

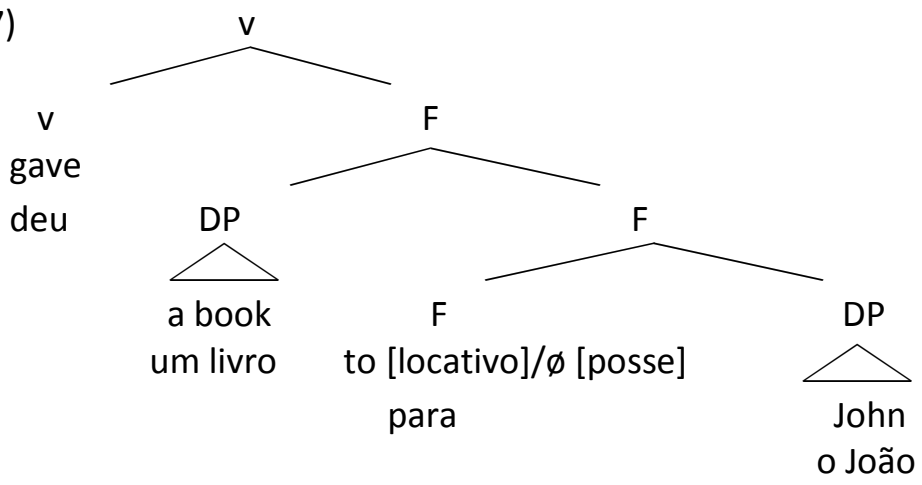

Como a estrutura dativa está disponível tanto em PB quanto em inglês, as duas línguas produzem a representação em (137) em LF. Em inglês, a presença de to é correlacionada à presença de [locativo], já que esse traço desencadeia a inserção desse conteúdo fonológico. Assim, os casos em que LF denota uma construção dativa, o conteúdo fonológico de to é inserido no componente morfológico. Nos casos em que a construção de objeto duplo é o conteúdo denotado em LF - graças à presença de [posse] - nessa estrutura, o conteúdo fonológico é nulo, o que desencadeia a regra de deslocamento compulsório, repetida aqui em 
(138). A aplicação dessa regra gera a estrutura em (139), que gera a alternância dativa, ou seja, a inversão dos argumentos internos do verbo give:

\section{Regra de Deslocamento Compulsório}

Um elemento ocupando a posição [Comp, F] deve se concatenar a [Spec, F], sempre que F não tiver conteúdo fonológico.

(139)

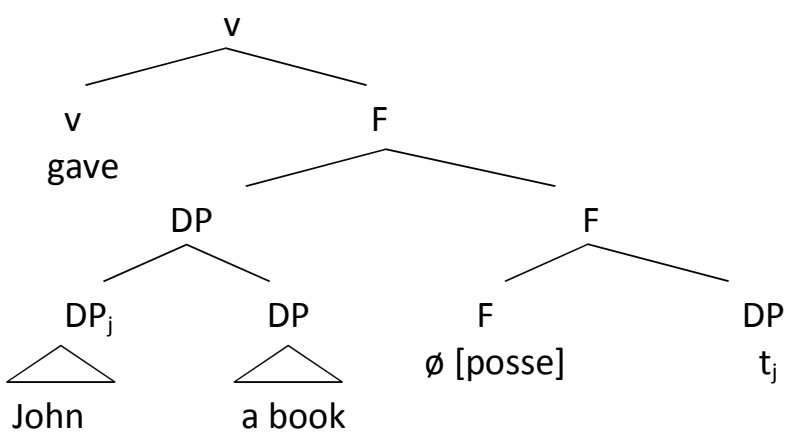

Dependendo do traço que o falante deseja ressaltar naquela sentença ([posse] ou [locativo]), a estrutura prototipicamente mais compatível com o traço (posse para objeto duplo, locativo para dativo) é selecionada desde o início da derivação, que, por sua vez, desencadeará (ou não) o efeito de preenchimento fonológico do núcleo F.

Ao contrário do que é dito na literatura, é proposto aqui que a os traços presentes na derivação garantem a interpretação relevante desde o início da formação da sentença. Esses traços controlam o produto da formação tanto das interpretações locativas quanto das interpretações de transferência de posse, o que se acredita ser uma opção melhor do que postular uma formação sintática distinta para cada variante da alternância, para que essa seja associada a determinada interpretação. Considerando os dados de Bresnan \& Nikitina (2008) apresentados acima, a alternativa aqui proposta se justifica. 
Apesar dessa preferência de estruturas definir a realização superficial de determinadas construções, não é possível apresentar leituras de transferência de posse para construções dativas em inglês, por exemplo. Por outro lado, essa ambiguidade é vista em PB. Esse fato se dá por não haver diferença na realização fonológica do traço [posse] e do traço [locativo]. Em $\mathrm{PB}$, o mesmo item de vocabulário preenche qualquer um dos traços, o que torna a estrutura ambígua, e, consequentemente, passível de apresentar as duas interpretações da alternância dativa do inglês - sem mencionar a ambiguidade de para como benefactivo, o que resulta, em alguns dialetos, numa terceira interpretação.

A análise aqui proposta é desejável, pelo fato de relacionar um tipo de predicado complexo ao Parâmetro de Realização Fonológica de Núcleos, além de manter a mesma proposta de estrutura para os compostos. Com essa aproximação entre compostos e a alternância dativa, esta tese apresenta um novo ponto de vista sobre a hipótese de Snyder (1995, 2001), já que a possibilidade de formação de predicados complexos compartilha mais propriedades com a estrutura morfológica dos nomes compostos do que Snyder poderia prever.

Na verdade, a análise pode ir além desses fatos, quando se pensa na questão morfológica, e nas propostas baseadas em modelos derivacionais anteriores, como Larson (1988), por exemplo. Larson cita a questão de Caso inerente para o argumento alçado da posição de alvo, pois a sua atribuição de Caso não seria canônica na estrutura proposta dentro do modelo de Princípios e Parâmetros. Na estrutura proposta em (139), acima, o alvo também é alçado. Porém, a atribuição de Caso é resolvida antes de spell-out. Ou seja, apenas PF é afetada. Apesar disso, a questão de casos morfológicos surge de maneira interessante. Quando se pensa nas passivas das construções de objeto duplo do inglês (140)a, vê-se que seu correspondente em PB é impossível (140)b. Porém, quando uma forma pronominal é utilizada para representar o argumento com papel temático de alvo, a sentença pode ser gramatical, desde que acompanhada por um marcador de Caso como a ou para (140): 
(140)

a. John was given a book.

b. *John foi dado um livro.

c. *(Para/A) mim foi dado um livro como presente de aniversário.

d. ${ }^{*} \mathrm{Er} / \quad \mathrm{hm} \quad$ wurde ein Buch gegeben.

*Ele (nominativo)/ Ele (dativo) foi um livro dado

'Um livro foi dado a ele.'

(HAEGEMAN, 1994, p. 188)

Assim como no PB, no alemão é possível que um sujeito com a marca morfológica de dativo participe dessa construção (cf. (141)d). Essa observação resolveria uma questão levantada por Snyder (2001, nota 3), que afirma que alemão, apesar de apresentar compostos nominais, não apresenta construções de objeto duplo. Talvez, a questão esteja em como cada língua manipula seus elementos nominais, e qual o grau de compactação morfológica que ela permite. Estas questões serão retomadas nos capítulos seguintes.

\subsection{Conclusão}

Neste capítulo, foi mostrado que a alternância dativa do inglês, assim como os compostos $\mathrm{N}+\mathrm{N}$ dessa língua, é um produto do Parâmetro de Realização Fonológica de Núcleos, resultante da presença do traço [posse], que, por não apresentar correspondente fonológico na língua, obriga a ausência de conteúdo fonológico do núcleo F, que por sua vez sofre a operação de deslocamento compulsório. 
A partir de argumentos empíricos e teóricos, a escolha de uma análise derivacional foi justificada, assim como foi justificada a possibilidade de PB apresentar leituras dativas de [posse] e [locativo], dada a ambiguidade das preposições a/para nessa língua.

No próximo capítulo, as construções denominadas de predicados complexos puros no capítulo 2 serão o objeto de análise. Com base no trabalho de Barbosa (2008) sobre as construções resultativas, será proposta uma convergência entre a análise da alternância dativa, da análise de compostos nominais e dessas construções, de maneira a explicar a ausência de todas elas em PB, bem como aproximar a relação do Parâmetro de Composição de Snyder $(1995,2001)$ à distinção tipológica vista entre PB e inglês por meio das observações de Talmy (2000) e as emoldurações distintas dessas duas línguas. 


\title{
Capítulo 5
}

\section{Construções resultativas e construções}

\section{verbo+partícula: consequências da aplicação}

\author{
do Parâmetro de Emolduração
}

5.1. Retomando a discussão: o Parâmetro de Composição ainda se faz relevante?

No capítulo 2, foi proposta uma classificação para os predicados complexos elencados por Snyder (1995) como participantes do Parâmetro de Composição. Nessa classificação, três tipos de predicados complexos foram propostos dentro das propriedades sintático-semânticas observáveis das construções em questão: (i) os predicados complexos encaixados, (ii) os predicados pseudo-complexos e (iii) os predicados complexos puros.

A partir dessa separação, foi proposto que os predicados complexos encaixados, por estarem presentes no PB de maneira uniforme e apresentarem o padrão de lexicalização de línguas emolduradas pelo verbo (que é o caso do PB), não aparentam ser construções de fato 
relevantes para a discussão do Parâmetro de Composição. Já os predicados pseudo-complexos foram analisados no capítulo 4, e, se a análise proposta estiver correta, o Parâmetro de Realização Fonológica de Núcleos explica a formação dessas construções e a ausência de construções de objeto duplo e de compostos no PB, apesar da presença de construções dativas e locativas nessa língua. Dessa forma, resta analisar os predicados complexos puros (construções resultativas e construções verbo+partícula), já que este tipo de predicado complexo é representado exclusivamente pelos dados ausentes de maneira uniforme em PB.

É interessante notar que Snyder (1995) aponta a construção resultativa como o predicado complexo prototípico para definir se uma língua apresenta - ou não - predicados complexos. Apesar dessa asserção que condiciona fortemente as bases translinguísticas de sua proposta, o autor não apresenta dados de aquisição comprovando o surgimento de resultativas nos dados de aquisição por ele utilizados, argumentando que essas construções envolvam outros fatores gramaticais, e que, apesar de não surgirem cedo na gramática dos falantes de inglês, devam ser levadas em conta como o diagnóstico de marcação positiva de uma língua para o Parâmetro de Composição.

Ainda que essa questão sobre a proposta de Snyder (1995) seja ignorada e sua proposta seja aplicada para o PB, é complicado afirmar que o PB seja marcado negativamente para o Parâmetro de Composição, especialmente se o trabalho de Barbosa (2008), que defende a impossibilidade de formação de construções resultativas em PB, for tomado como correto. Apesar de ser possível afirmar que PB não apresenta resultativas, não é possível garantir alguns dos predicados complexos mencionados por Snyder (2001) e Sugisaki \& Snyder (2002) - conforme mostrado no capítulo 2 - não ocorram nessa língua. Além disso, foi visto, no capítulo 3, que existe um tipo de formação nominal em PB, formada por $\mathrm{N}+$ de $+\mathrm{N}$, muito próxima dos compostos do inglês, com exceção da presença fonológica do núcleo que relaciona os dois nomes do composto. 
Apesar de as afirmações empíricas feitas por Snyder $(1995,2001)$ não se sustentarem perante os dados do $\mathrm{PB}$, não é possível que o Parâmetro de Composição seja simplesmente descartado, pois ele apresenta uma série de observações pertinentes e aponta uma relação interessante entre a formação de uma série de construções sintáticas que estão aparentemente interligadas - mesmo que por motivos diferentes, conforme visto no capítulo 4.

Tomando por base as observações feitas até aqui, parece que o Parâmetro de Composição lida com mais estruturas do que deveria, e que línguas como o PB não sejam estruturalmente tão diferentes do inglês, ao menos no que diz respeito às possibilidades de denotação de alguns desses fenômenos. Por isso, este capítulo mostrará que a restrição sobre construções resultativas e construções verbo+partícula em PB é fruto de um parâmetro distinto daquele que explica a presença/ausência de nomes compostos e os predicados complexos analisados no capítulo 4.

Analisar as construções resultativas e verbo+partícula e relacionar suas características sintáticas às propriedades tipológicas apontadas a partir do trabalho de Talmy (2000) será o objetivo principal deste capítulo. Graças à relação entre a tipologia de Talmy e os dados do inglês e do PB, foi possível demonstrar que, para que a cobertura empírica proposta por Snyder (1995) seja representada sintaticamente de maneira eficiente, o Parâmetro de Composição necessita ser dividido em dois parâmetros distintos: (i) o Parâmetro de Emolduração ((25), capítulo 1), e (ii) o Parâmetro de Realização Fonológica de Núcleos ((136), capítulo 4). Essa distinção parece se justificar quando são levadas em conta as observações empíricas feitas até aqui, em especial as características sintáticas de cada um dos dois tipos de predicados complexos (pseudo-complexos e complexos puros).

A partir das noções de estrutura argumental de Hale \& Keyser (2002), será adotado que a projeção que forma construções resultativas seja a diádica composta em oposição ao comportamento da estrutura diádica básica. A estrutura diádica básica, por sua vez, forma os 
compostos e construções locativas e de alternância dativa. Antes disso, a análise de Barbosa (2008) - ponto de partida para as considerações deste capítulo - será apresentada brevemente na próxima seção.

\subsection{Derivando o Parâmetro de Emolduração a partir dos predicados complexos puros}

5.2.1. Não existem construções resultativas em PB: Barbosa (2008)

Barbosa (2008) faz um estudo das construções resultativas do inglês, e argumenta contra a existência de um fenômeno equivalente a essas construções em PB. Apesar de aparentes semelhanças superficiais, é mostrado que as construções chamadas de "resultativas do PB" na literatura compreendem um tipo diferente de estruturas de predicação secundária, pois existe uma diferença semântica quanto ao tipo de modificação que o predicado resultativo exerce sobre a sentença em inglês e em PB. Enquanto o predicado resultativo em inglês denota o estado resultante da ação, o predicado secundário "resultativo" em PB é, na verdade, um modificador do estado resultante, já denotado pelo conteúdo semântico expresso no complexo verbo+argumento interno. Essa distinção permite explicar as diferenças de acarretamento e de paráfrases entre (141) e (142), abaixo: 
(141) a. John hammered the metal flat.
$\rightarrow$ The metal was hammered.
('O metal foi martelado')
$\rightarrow$ The metal got flat.
('O metal ficou achatado')
$\rightarrow$ The metal was flattened.
('O metal foi achatado')

b. John flattened/caused the metal to become flat by hammering it.

'João achatou/deixou o metal achatado martelando-o.'

(BARBOSA, 2008, p. 63)

(142) a. Ele martelou o prego torto.

$\rightarrow$ O prego foi martelado. (cf. Ele martelou o prego)

$\rightarrow O$ prego ficou torto. (cf. $\neq$ Ele entortou o prego)

$\rightarrow$ ?O prego foi entortado. (cf. $\neq$ Ele entortou o prego)

b. ?Ele entortou/deixou o prego torto martelando-o.

(BARBOSA, 2008, p. 64)

Retomando as representações de Talmy em (20) e (21), repetidas em (143) e (144), abaixo, é mostrado que a lexicalização de certos traços e os verbos em línguas germânicas é diferente da lexicalização em línguas românicas, o que afeta a possibilidade de formação de resultativas. Enquanto inglês realiza a semântica de estado resultante em um satélite, e modo e causa amalgamados ao verbo (143), PB realiza no verbo os traços de causa e estado resultante amalgamados ao verbo, e o modo é denotado pelo predicado secundário (144): 
(143)

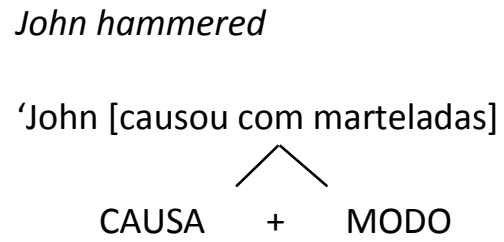

the metal flat.

o metal [ficar achatado]'

ESTADO RESULTANTE

John flattened/caused the metal to become flat by hammering it.

'João achatou/deixou o metal achatado martelando-o.'

(BARBOSA, 2008, p. 51)

(144)

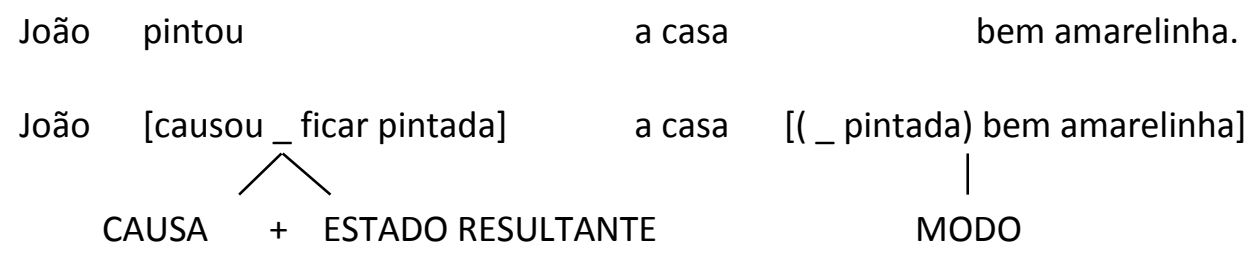

(adaptado de BARBOSA, 2008, p. 80)

A restrição de formação desses predicados complexos em PB seria explicada pela marcação negativa do Parâmetro de Composição nessa língua, (Snyder, 1995), que impediria a inserção de itens lexicais de classe aberta (raízes) em posições marcadas com o traço [+Afixal].

Em uma análise baseada na teoria de estrutura argumental de Hale \& Keyser (2002), Barbosa (2008) propõe que as raízes do inglês sejam marcadas com o traço [+Afixal], formando a estrutura em (145). No caso do PB, as raízes não podem ser marcadas com esse traço, o que explica a impossibilidade de leitura resultativa (146), e o bloqueio da estrutura em (147):

(145)

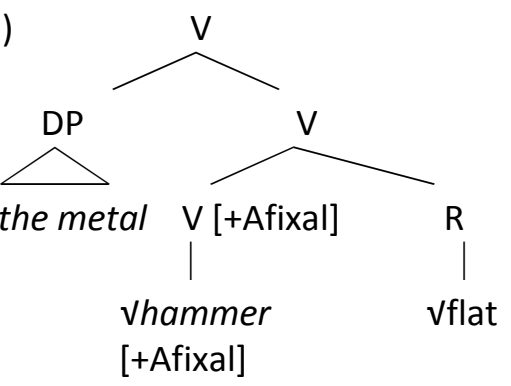

(BARBOSA, 2008, p. 108) 
(146) $\quad \neq$ O João martelou o metal plano.

(BARBOSA, 2008, p.109)

(147)

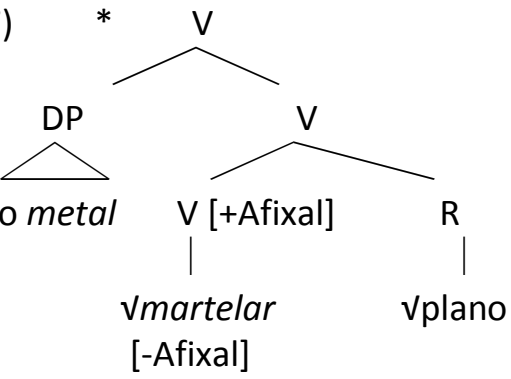

(BARBOSA, 2008, p.109)

Seguindo a proposta de Hale \& Keyser (2002), Barbosa (op. cit.) afirma que as estruturas para as construções resultativas do inglês seriam as mesmas para os verbos de alternância causativo-incoativa. No caso do PB, resultativas não ocorrem, pois raízes não podem aparecer em V, mas morfemas como [a-] em achatar são possíveis, gerando estruturas como (149):

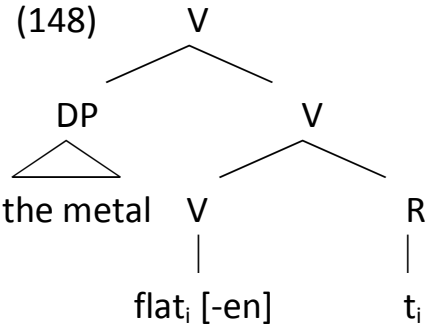

(BARBOSA, 2008, p.110)

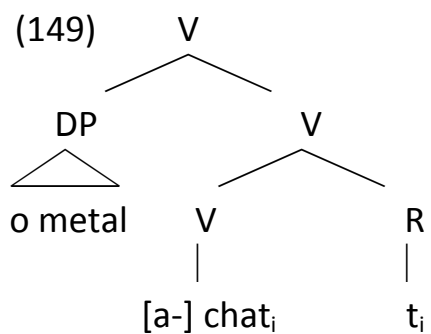

(BARBOSA, 2008, p.110) 
Aproveitando as definições acima como ponto de partida para uma nova análise para os predicados complexos puros, a questão da idiomaticidade será discutida na próxima seção, onde a relação entre esses predicados complexos e nomes compostos será observada com maior detalhamento.

\subsubsection{Idiomaticidade em resultativas, verbo+partícula, e nomes compostos}

Nos trabalhos sobre o Parâmetro de Composição, Snyder $(1995,2001)$ faz questão de apontar exatamente os predicados complexos puros como os detentores de um grau maior de proximidade empírica aos nomes compostos. Observar quais as propriedades que essas construções compartilham entre si pode ser uma maneira de explicar a relação defendida por Snyder, apesar de a análise nesta tese caminhar em direção contrária a essa relação, já que não são apenas um, mas dois parâmetros que derivam as diferenças entre línguas como inglês e PB.

Em primeiro lugar, algumas das propriedades ditas sintáticas dos nomes compostos, tais como recursividade e estrutura interna de constituintes com interpretação composicional parecem se repetir nos predicados complexos puros de uma forma ou outra. Essas e outras propriedades serão analisadas nos predicados complexos "puros", ou seja, as construções resultativas e construções verbo+partícula ${ }^{53}$.

Uma das relações que nomes compostos e predicados complexos compartilham é a sua interpretação idiomática. Em construções resultativas, é possível ver interpretações

\footnotetext{
${ }^{53} \mathrm{Na}$ análise feita nesta tese, não serão levadas em consideração as construções conhecidas como isolamento de preposição, já que, conforme dito anteriormente, são consideradas consequência da presença de construções verbo+partícula em uma determinada língua.
} 
idiomáticas quando essas construções são formadas com PPs. Com exceção dos casos em que o PP denota um lugar ou posse inalienável (150), a interpretação desse PP é idiomática, como é possível ver pela tradução das sentenças em (151) e (152):

(150)

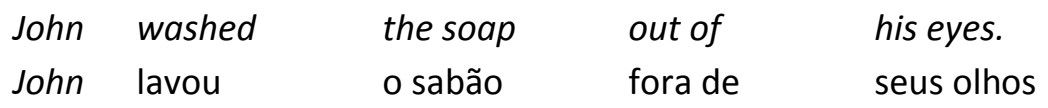

'John lavou os seus olhos até tirar o sabão deles/tirou o sabão de seus olhos lavando-os'

(HOEKSTRA, 1988, p.116)

(151)

$\begin{array}{lllll}\text { They ate } & \text { us } & \text { out of house and home. } \\ \text { Eles comeram } & \text { nós } & \text { fora de casa e lar }\end{array}$

'Eles nos deixaram sem ter o que comer em nossa casa, comendo tudo o que tínhamos'

(HOEKSTRA, 1988, p.116)

$(152)$

$\begin{array}{llll}\text { She laughed } & \text { him } & \text { out of } & \text { his patience. } \\ \text { Ela riu } & \text { ele fora de } & \text { sua (masc.) paciência }\end{array}$

'Ela riu até tirar ele do sério/Ela tirou ele do sério rindo'

(HOEKSTRA, 1988, p.115)

É possível observar, ainda, que algumas construções consideradas resultativas por alguns autores são compostas por partículas, como (153):

$\begin{array}{llll}\text { Sylvester } & \text { cried } & \text { his eyes } & \text { out. } \\ \text { Sylvester } & \text { chorou } & \text { seus olhos } & \text { fora }\end{array}$

'Sylvester chorou até seus olhos caírem/tirou seus olhos de tanto chorar'.

(LEVIN; RAPPAPORT-HOVAV, 1995, p. 41) 
Outra questão relevante diz respeito aos phrasal verbs, formações sintáticas de verbo+partícula, como take in (enganar), knock up (engravidar), ou carry out (desempenhar). Marcelino (2000) aponta para o seguinte fato:

\begin{abstract}
“... as partes individualmente não tem muito a ver com o significado final da combinação verbo+partícula (V + PRT). Nesse caso, diremos que a partícula adverbial muda o significado do verbo isolado, construindo um significado idiomático, idiossincrático ${ }^{54,55 "}$.
\end{abstract}

(MARCELINO, 2000, p. 63)

Nas construções resultativas, os predicados envolvidos são ambos responsáveis pela denotação do evento, no sentido em que o estado resultante somente é obtido através da ação denotada pelo verbo. Já em construções com verbo+partícula, é mais difícil perceber a noção de idiomaticidade de predicados. Ramchand \& Svenonious (2002) mostram que existem certas propriedades nas partículas que são responsáveis pela formação dessas construções. Enquanto a partícula atélica around é responsável pela seleção do objeto direto em (154)b, ela não é capaz de mover-se junto com o verbo (154)c; por outro lado, partículas resultativas como down (155) são capazes de alternar dessa forma. Em ambos os casos, a interpretação é idiomática, daí a impossibilidade de (154) $\mathrm{a}^{56}$.

\footnotetext{
${ }^{54}$ É interessante observar que um dos phrasal verbs citados pelo autor, make up, é também um nome em inglês. Essa semelhança é um argumento para uma análise que explique a formação de palavras e sentenças a partir da mesma estrutura sintática - no caso, nomes compostos e predicados complexos.

${ }^{55}$ Existem outras combinações de verbo+partícula abordadas por Marcelino (2000), como warm up (aquecer), burn out (queimar), break down (quebrar). Ao contrário dos phrasal verbs mencionados acima, essas outras combinações não apresentam efeitos de idiomaticidade. Aparentemente, a idiomaticidade não é restrita a um tipo específico de partícula ou de verbo, sendo aparentemente opcional - assim como no caso das construções resultativas. (cf. (151)-(153), acima).

${ }^{56}$ É importante notar que (154)a é agramatical na leitura relevante, considerando-se tanto (154) quanto (155)b.
} 
(154)

a.??We ran Mary.

Nós corremos Mary

'Nós corremos Mary.'

b. We ran Mary around (in our car) (for hours).

Nós corremos Mary ao redor (em nosso carro)(por horas)

'Nós passeamos com a Mary (em nosso carro) (por horas).'

c. *We ran $\quad$ around $\quad$ Mary.

Nós corremos ao redor Mary

‘Nós corremos ao redor de Mary/*Nós passeamos com a Mary (leitura relevante)'.

(RAMCHAND; SVENONIOUS, 2002, p. 399, tradução minha)

(155)

a. We ran Mary down.

Nós corremos Mary baixo

'Nós atropelamos a Mary.'

b. We ran down Mary.

(RAMCHAND; SVENONIOUS, 2002, p. 399, tradução minha)

Outra propriedade que nomes compostos e predicados complexos puros compartilham (de certa forma) é a recursividade. Conforme mostrado no capítulo 3, nomes compostos no inglês podem ser altamente recursivos (cf. (156), abaixo).

(156)

a. car cleaning cloth drawer

carro limpeza pano gaveta

'gaveta do pano de limpar o carro' 
b. silver spoon fed rich boy
prata colher alimentado rico menino
'menino (tão rico que é) alimentado com colher de prata'

c. roman candle firework $\quad$ Hollywood hot
romana vela fogo de artifício $\quad$ Hollywood quente
pink love
rosa amor
'amor cor-de-rosa, quente, de Hollywood, de fogos de artifício (do tipo)
espada (vela romana ${ }^{57}$ )

Além da recursividade, alguns nomes compostos apresentam uma espécie de leitura quantificacional, como (156)b. Predicados complexos como construções resultativas não são recursivas como os nomes compostos, mas apresentam o mesmo tipo de leitura quantificacional (cf. (150)-(152), acima; (157)).

(157) John hammered the metal flat.
John martelou o metal plano/achatado John martelou o metal até ele ficar plano/achatado/João fez o metal ficar plano/achatado de tanto martelá-lo'

Será defendido aqui que a diferença entre a recursividade entre compostos e resultativas se dê pelo fato de se tratar de projeções F diferentes. Com as noções de Marantz ${ }^{57}$ A tradução da expressão roman candle, do inglês (lit. 'vela romana'), significa espada-de-fogo
(http://pt.wikipedia.org/wiki/Festa junina). 
(2001) em mente, juntamente com a definição obtida pelo Parâmetro de Emolduração (cf.

capítulo 2), a proposta de estrutura para os predicados complexos puros seria a seguinte:

(158)

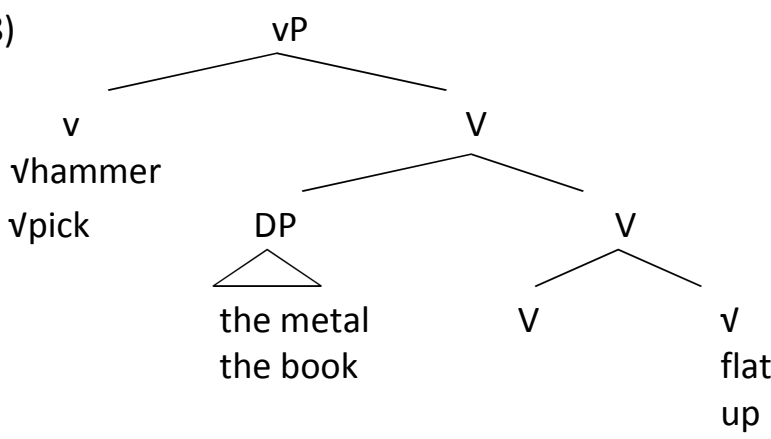

Por ser o núcleo categorizador que "idiomatiza" e licencia a estrutura em (158), a relação temática "compartilhada" entre o verbo e o complemento de $\mathrm{V}$ (flat, up) sobre o argumento interno (especificador de V) se mantém. Esse tipo de estrutura sintática é semelhante a uma mini oração, análise comumente aplicada às construções resultativas (HOEKSTRA, 1988, HARLEY, 2007), às construções verbo+partícula (KAYNE, 1985, HARLEY, 2007), e às construções de objeto duplo (HARLEY, 2007) ${ }^{58}$.

Com essa configuração, a diferença entre as interpretações idiomáticas dos compostos e das construções em questão se explicam. A natureza de $\mathrm{F}$ nos compostos aparenta ser mais próxima à de uma preposição - uma projeção diádica básica, nos termos de Hale \& Keyser $(2002)^{59}$ - já que sua leitura idiomática possui escopo sobre o especificador e o complemento da projeção F, que é atribuída por $n$ (cf. (159), abaixo). No caso dos predicados complexos puros, o núcleo categorizador $v$ não interfere na "idiomatização", já que o objeto intervém

\footnotetext{
${ }^{58}$ Para uma proposta de projeção funcional para as mini orações, cf. Schein (1982/1995) e Moro (1995).

${ }^{59}$ Hale \& Keyser (2002) distinguem estruturas diádicas básicas (um único núcleo exige semanticamente a seleção de dois argumentos) e diádicas compostas (o núcleo seleciona semanticamente o complemento, e este, por sua vez, faz a restrição semântica do elemento na posição de especificador da projeção). Os autores propõem que projeções diádicas básicas tendam a ser lexicalizadas por $P$, enquanto projeções diádicas compostas sejam lexicalizadas por V.
} 
entre $v$ e essas raízes, já categorizadas pelo $V$ inferior. Isso permite que, seja qual for a natureza do argumento - desde que ele satisfaça os critérios temáticos dos predicados que o selecionam -, ele não afete a interpretação composicional entre o verbo e o predicado secundário.

(159)
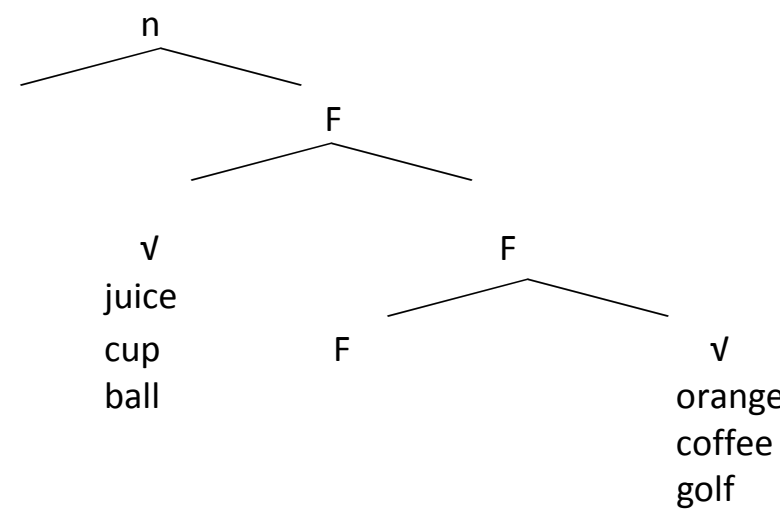

Apesar de lidar com a questão do domínio idiomático dos predicados complexos, a estrutura em (159) ainda não é capaz de explicar a questão empírica colocada pelas análises de predicação complexa (CHOMSKY, 1955/1975, LARSON 1988, NEELEMAN; VAN DE KOOT, 2002, ROTHSTEIN, 2004, BARBOSA, 2008, e as referências lá citadas). Um teste a favor da análise de predicados complexos para construções resultativas é sugerido em Rothstein (2004). A autora mostra que os argumentos das resultativas são responsáveis por determinar a telicidade do VP; logo, o objeto nas resultativas não seria argumento do verbo somente, nem de uma SC, mas de um predicado complexo, caso contrário, não estaria disponível semanticamente para permitir a interpretação atélica, quando na forma de um plural nu (160)a:

(160) a. John sang babies asleep for hours/*in an hour last night.

b. John sang 3 babies asleep *for hours/in an hour last night.

(ROTHSTEIN, 2004, p. 81) 
Seria possível dizer que, se a hipótese de Marantz (2001) está correta e o significado da raiz no contexto de x"zinho" é "negociado", então o complemento de um núcleo como $\mathrm{V}$ em (158) (acima) ainda não afetaria a telicidade da sentença, nem correria o risco de afetar a relação composicional do verbo e do predicado secundário, já que seu significado é negociado pelo categorizador $n$, dentro do DP que o constitui. Logo, (160) não seria um problema para a análise do tipo mini oração, já que o DP (ou talvez um NP, no caso de (160)a) não seria afetado pelas questões de predicação complexa. Porém, com a estrutura em (158) não seria possível explicar dados como (161): John wiped clean the table.

A solução para essa questão empírica seria dizer que a raiz que forma o predicado complexo nessas construções seja gerada no núcleo da projeção $\mathrm{V}$, movendo-se posteriormente para $v$ nos casos de ordem mais canônica, ou sofrendo reanálise, com alçamento dos dois elementos que formam o predicado complexo (cf. LARSON, 1988), nos casos em que os predicados se encontram em adjacência fonológica, como em (161), acima:

(162)

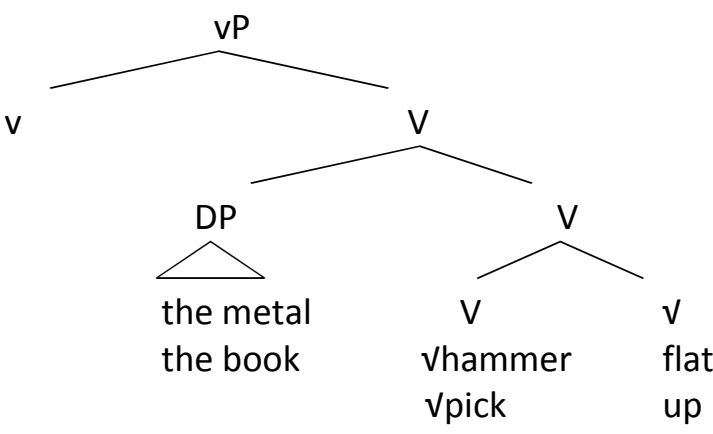

Essa estrutura possui muitas semelhanças com a análise desenvolvida por Barbosa (2008), em que a configuração sintática de construções resultativas é baseada na proposta de 
verbos deadjetivais de Hale \& Keyser (2002). Assim como na análise de Barbosa (2008), a presença do o traço de [modo] no núcleo formador do predicado complexo licencia a presença de uma raiz nessa posição. Retomando a ideia contida na proposta original do Parâmetro de Composição (SNYDER, 1995), repetido abaixo em (163), raízes - itens não afixais, seriam capazes de ocupar a posição do núcleo de V. No caso de afixos formadores de verbos deadjetivais, a raiz na posição de complemento de $V$ se moveria para o núcleo (cf. BARBOSA, 2008, p.110).

(163) Parâmetro de Composição: A gramática (não) permite livremente que itens lexicais de classe aberta, não afixais, sejam marcados [+Afixal].

(SNYDER, 1995, p. 27, tradução minha)

Até aqui, foram mostrados argumentos em favor de uma estrutura em comum para predicados complexos puros e nomes compostos. Na seção a seguir, a proposta de Barbosa (2008) será tomada como base para a definição da estrutura de predicados complexos puros, adaptada às noções do Parâmetro de Emolduração, proposto no capítulo 2.

5.3. O Parâmetro de Emolduração e sua relação com [modo] nos predicados complexos puros

As estruturas de Barbosa (2008) mostradas acima, ao contrário da análise proposta para as construções de alternância dativa, mostram uma relação diferente de predicação, 
apesar de também contarem com uma projeção funcional (verbal) para a delimitação do predicado complexo em questão. Numa tentativa de adaptação da proposta de Barbosa (2008) para as análises feitas nos capítulos 3 e 4, qual seria a melhor estrutura para essas construções, caso fosse adotada a ideia da projeção F? Assumindo o mapeamento sintático das propriedades tipológicas de Talmy (2000) proposto por Mateu \& Rigau (1999) (cf. capítulo 2) e o Parâmetro de Emolduração ((25), repetido abaixo em (164)), a projeção $F$ (nesse caso, V) seria a responsável pela denotação do traço [modo] (ao invés de [+Afixal], cf. (163), acima), permitindo, por sua vez, que a raiz hammer denote o modo da ação em uma construção resultativa:

$(164)$

\section{Parâmetro de Emolduração}

Uma língua denota [modo] em $v$.

$$
\{\operatorname{sim}\}=\text { inglês }
$$$$
\{\text { não }\}=P B
$$

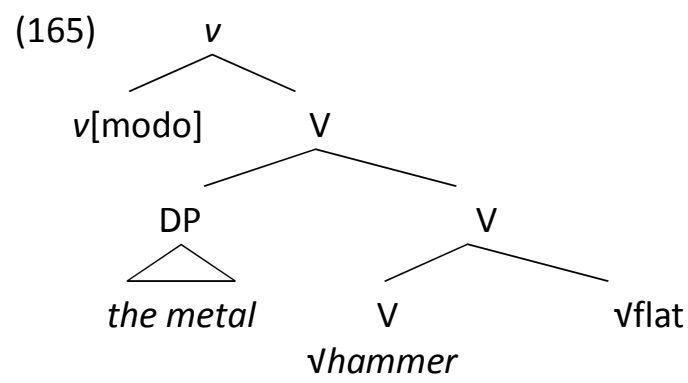

Nessa estrutura, a justificativa para a presença da raiz hammer sendo gerada como núcleo de $V$ e não diretamente inserida em $v$ se perde, já que não há mais traço de [modo] em V, ou na raiz. Assim, a única maneira de determinar a estrutura acima como uma resultativa é a partir da interpretação de [modo] em v. Ainda assim, é necessário excluir casos como (167), 
para que uma sentença de alternância causativo-incoativa como (166) não denote modo. Um argumento para dizer que (166) não denota modo seria a possibilidade de inserção de adjunto que denote modo (168)a, algo impossível nas resultativas (168):

(166) John flattened the metal.

(167)

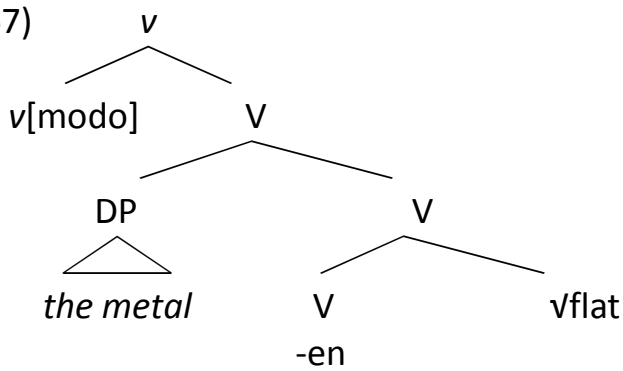

(168) a. John flattened the metal (by hammering it).

b. John hammered the metal flat (*by kicking it).

Com a definição em (164) surge, ainda, outra questão: $F$ aparenta ser uma categoria verbal nos casos como (165), o que vai contra as análises dos capítulos 3 e 4, pois o núcleo de $F$ nas estruturas anteriormente propostas é realizado fonologicamente por uma preposição.

Por conta desses problemas, a restrição expressa em (164) deve ser reformulada, já que a variação translinguística vista por Talmy (2000) trata de construções de movimento ou mudança de estado - caso dos predicados complexos puros, e, para dar conta da cobertura empírica desejada nesta tese, o Parâmetro de Emolduração precisa ser definido da seguinte maneira:

(169) Parâmetro de Emolduração (revisado)

Uma língua permite que uma raiz denote [modo] em $v$.

$$
\begin{aligned}
& \{\operatorname{sim}\}=\text { inglês } \\
& \{\text { não }\}=P B
\end{aligned}
$$


Com o Parâmetro de Emolduração formulado dessa maneira, a proposta de [modo] denotado pelo verbo em inglês se justifica nas resultativas, já que não seria possível uma leitura de [modo] para uma estrutura do inglês como (167), acima, nem uma interpretação resultativa para (170), abaixo, no caso do PB. Apesar da configuração estrutural idêntica às resultativas, é somente o traço de [modo] em $v$ o fator que impede que essa construção seja bem-formada.

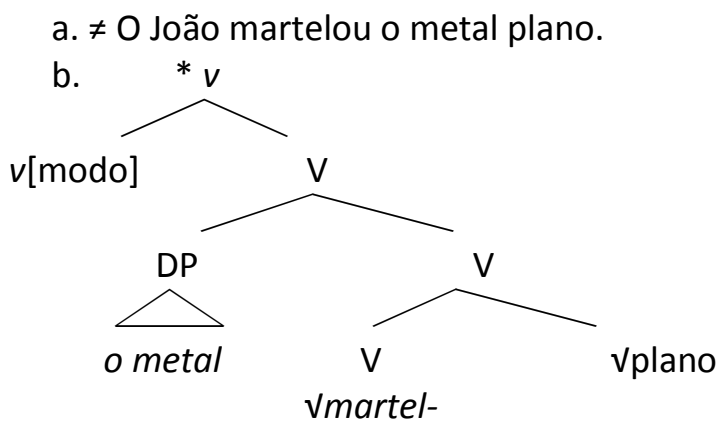

Seguindo a proposta de Kayne (1994), e Larson (1988, p. 345-346, nota 11), adjuntos devem ser c-comandados pelo verbo - caso de plano, em (170) - ao invés da tradicional adjunção à direita, sobre a projeção máxima de VP. Dessa maneira, o que diferencia uma construção resultativa (cf. (165), acima) de uma sentença como (170)a é a interpretação composicional que o traço de [modo] em $v$ desencadeia no inglês, e que no PB é codificado no $a P$. Dessa forma, a diferença translinguística entre PB e inglês para as construções resultativas é explicada pelo Parâmetro de Emolduração. 


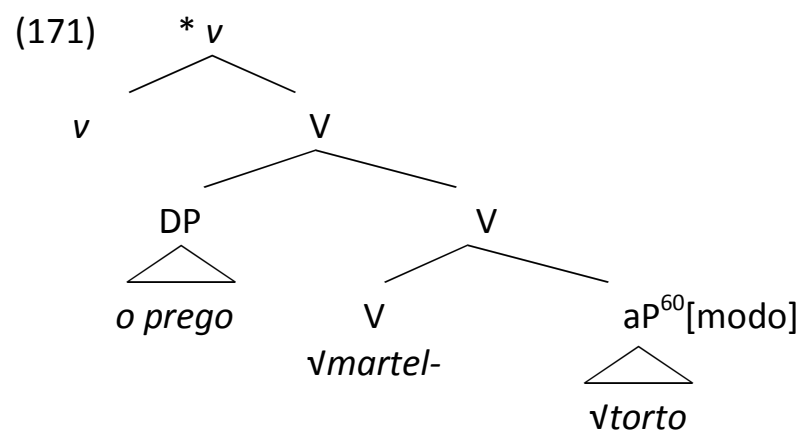

Outra decorrência da análise adotada é que não existam verbos que denotem modo em PB. Essa afirmação vai em direção oposta aos trabalhos de Bassani $(2009 a, b)$ e Amaral (2010), que afirmam haver algumas instâncias de modo em verbos do PB. Amaral observa os verbos de modo de movimento em PB, que, de acordo com a autora, "são verbos que descrevem o movimento de um objeto pelo ponto de vista do modo como se dá esse movimento, sem que haja a descrição de uma trajetória". Observando as contrapartes para os verbos observados por Amaral (2010), é clara a diferença quantitativa em termos de produtividade para a expressão de modo. Em uma busca por dois dicionários de sinônimos online - http://thesaurus.com para o inglês, e http://www.sinonimos.com.br para o PB - é possível observar nos dados abaixo que a proporção de sinônimos para esses verbos de "modo" são muito maiores em inglês:

${ }^{60}$ Embick (2004) afirma que flat em estruturas como (162) e (167), acima, deva ser considerado um aP, e não somente uma raiz, já que é possível acrescentar modificadores a esse adjetivo, como em (i):

(i) John hammered the metal flatter/completely flat/as flat as a pancake.

(EMBICK, 2004, p. 370)

A questão dos complementos e especificadores de V (ou ainda, de F) será abordada ao longo deste capítulo. 
(172) Pares de verbos de modo de movimento: inglês versus PB

\section{a. sacudir - shake}

Sinônimos para sacudir

abanar, agitar, balançar, brandir, chacoalhar, empurrar, estremecer, mover, sacolejar, tremer, trepidar, vibrar.

Sinônimos para shake

agitate, brandish, bump, chatter, churn, commove, concuss, convulse, discompose, disquiet, disturb, dither, dodder, flap, flicker, flit, flitter, flourish, fluctuate, flutter, jar, jerk, jog, joggle, jolt, jounce, move, oscillate, palpitate, perturb, quail, quake, quaver, quiver, rattle, reel, rock, roil, ruffle, set in motion, shimmer, shimmy, shiver, shudder, stagger, stir up, succuss, sway, swing, totter, tremble, tremor, twitter, upset, vibrate, waggle, water, wave, whip, wobble.

\section{b. quicar - bounce}

Sinônimos para quicar

pular, saltar.

Sinônimos para bounce

ax, boot out, can, discharge, dismiss, eighty-six, eject, evict, fire, give one notice, give the heave ho, heave, kick out, oust, sack, terminate, throw.

\section{c. girar - turn}

Sinônimos para girar

ambular, andar, circuitar, circular, correr, corrupiar, deambular, divagar, gravitar, percorrer, passear, perambular, remoinhar, rodar, rodear, rodopiar, rotar, sair, transitar, vagar, vaguear, virar, voltar, voltear, volutear, volver. 


\section{Sinônimos para turn}

about-face, aim, alter, alternate, arc, backslide, bend, call off, capsize, change, change course, change position, circle, circulate, circumduct, come around, convert, corner, curve, cut, depart, detour, detract, deviate, digress, direct, diverge, double back, eddy, face about, go around, go back, go round, ground, gyrate, gyre, hang a left, hang a right, incline, inverse, invert, loop, make a left, make a right, move, move in a circle, negotiate, orbit, oscillate, pass, pass around, pirouette, pivot, rechannel, recoil, redirect, regress, relapse, retrace, return, reverse, revert, revolve, roll, rotate, round, sheer, shift, shunt, shy away, sidetrack, spin, subvert, sway, swerve, swing, swirl, switch, swivel, tack, take a bend, transform, twirl, twist, upset, vary, veer, vibrate, volte-face, weave, wheel, whip, whirl, wind, yaw, zigzag.

Além da baixa produtividade de expressões verbais que indicam [modo] em PB, é possível citar a questão da interpretação desses dados. Em estruturas de mudança de estado, é simplesmente impossível obter uma leitura em que a ação verbal indique um modo pelo qual seja gerado um estado resultante, como nas construções resultativas. Bassani (2009a), num estudo dos verbos denominais do PB, afirma que as sentenças em (173) "permitem a adição de um sintagma preposicional revelador do instrumento utilizado, espaço delimitado ou um verbo que revela o modo de executar a ação expressa pelo verbo":

(173) a. O Pedro martelou os pregos com o martelo grande.

b. O Pedro colocou os pregos martelando.

c. O funcionário engarrafou os vinhos em garrafas de plástico.

d. É um pecado selar os cavalos com sela apertada.

(BASSANI, 2009a, p.10) 
Apesar de denotarem uma ação específica, verbos como martelar, engarrafar, ou selar não denotam [modo] da ação, de fato, mas apenas instrumento ou uma especificação do estado resultante da ação. Um verbo como martelar, por exemplo, não expressa o modo com que esses estados resultantes vieram a acontecer. Apesar de ser possível a substituição de martelar por outros verbos que aparentemente, denotariam [modo] (174), nenhum deles passa nos testes de passiva adjetival vistos em (175), em contraste aos verbos do inglês em (176):

(174) O Pedro martelou/forçou/apertou/empurrou o prego na parede.

(175) a. O Pedro martelou o prego. $\rightarrow \neq 0$ prego ficou martelado.

a'. O Pedro martelou o prego na parede. $\rightarrow$ O prego ficou (?martelado) na parede.

b. O Pedro forçou o prego. $\rightarrow \neq 0$ prego ficou forçado.

b'. O Pedro forçou o prego na parede. $\rightarrow$ O prego ficou (?forçado) na parede.

c. O Pedro apertou o prego. $\rightarrow$ O prego ficou apertado.

$c^{\prime}$. O Pedro apertou o prego na parede. $\rightarrow$ O prego ficou (?apertado) na parede.

d. O Pedro empurrou o prego. $\rightarrow$ ?O prego ficou empurrado.

d'. O Pedro empurrou o prego na parede. $\rightarrow$ O prego ficou ( $\neq$ empurrado) na parede.

(176) a. Peter hammered/axed/wrenched/shoveled the nail to the wall.

(177) a. Peter hammered the nail. $\rightarrow$ The nail got hammered.

a'. Peter hammered the nail to the wall. $\rightarrow$ The nail got hammered to the wall.

b. Peter axed the nail. $\rightarrow$ The nail got axed.

$b^{\prime}$. Peter axed the nail to the wall. $\rightarrow$ The nail got axed to the wall. 
b. Peter wrenched the nail. $\rightarrow$ The nail got wrenched.

$b^{\prime}$. Peter wrenched the nail to the wall. $\rightarrow$ The nail got wrenched to the wall.

b. Peter shoveled the nail. $\rightarrow$ The nail got shoveled.

$b^{\prime}$. Peter shoveled the nail to the wall. $\rightarrow$ The nail got shoveled to the wall.

Nos casos do inglês, é possível ver que o verbo contribui para a denotação do estado resultante da ação hammer to the wall. Propõe-se aqui que essa seja uma característica fundamental para determinar que um verbo realiza [modo]. Outra propriedade característica do inglês mencionada na literatura é a capacidade de "transformar qualquer nome em um verbo". Como é possível ver pelos verbos em (178)a, abaixo, os verbos utilizados apresentam a mesma realização morfológica dos nomes dos instrumentos que os nomeiam, algo completamente estranho em PB (178)a'. É provável que martelar seja um caso marginal, e que o PB apresente essa rejeição em formar verbos dessa maneira.

a. Peter hammered/axed/wrenched/shoveled the nail to the wall.

a'. O Pedro martelou/*machadou/*chave-inglesou/*pasou o prego na parede.

b. Peter let/axed/wrenched/shoveled the nail flat.

b'. O Pedro deixou/*machadou/*chave-inglesou/*pasou o prego plano.

É possível notar ainda que é essa propriedade "nominal" dos verbos em inglês permite com que as construções resultativas como (178)b sejam tão produtivas, enquanto em PB, só verbos "canônicos de causa" ${ }^{61}$ como deixar poderiam entrar em uma formação sintática semelhante e manter a construção gramatical. Claramente, a impossibilidade de [modo] em $v$

\footnotetext{
${ }^{61}$ Convém ressaltar que, apesar de serem verbos "canônicos de causa", não existe uma correlação necessária entre construções causativas e construções que apresentam uma mudança de estado externamente causada - caso das construções resultativas.
} 
no PB impede a leitura resultativa, afetando a variedade de expressão possível de significados distintos em estruturas como (178).

Apesar dessa propriedade nominal, será seguido aqui que esses verbos são formados diretamente de raízes, e que suas propriedades são mais referenciais (em oposição a raízes mais estativas ou mais predicativas). Na próxima seção, serão retomadas as diferenças entre as estruturas propostas para os predicados complexos puros, e as relações entre raízes e DPs nas projeções funcionais F e V, numa adaptação da proposta de Hale \& Keyser (2002) dentro do conjunto de axiomas da Morfologia Distribuída (HALLE; MARANTZ, 1993).

\section{4. $V, F$ ou $P$ ? Estrutura argumental e as questões lexicais na variação paramétrica}

Nesta seção, serão discutidas questões técnicas acerca das propriedades das projeções funcionais responsáveis pela variação paramétrica entre inglês e PB mostradas ao longo desta tese. Conforme discutido no capítulo 2, estão presentes no PB ao menos quatro "predicados complexos" que, de acordo com Snyder (2001) e Sugisaki \& Snyder (2002), deveriam ser exclusividade de línguas que formam compostos $\mathrm{N}+\mathrm{N}$ de maneira produtiva: (i) construções causativas, (ii) construções perceptuais, (iii) construções dativas e (iv) construções locativas. Dessa forma, o foco da tese voltou-se para as construções que seriam relevantes para a definição formal de um parâmetro empiricamente adequado ao desafio apresentado a partir da consideração dos dados do PB. De acordo com a classificação de predicados complexos aqui proposta, foi possível classificar dois tipos de fenômenos sintáticos representados por representações estruturais diferentes, e que lidam com dois grupos de dados: (i) nomes 
compostos, construções de objeto duplo (e construções dativas), e (ii) construções resultativas e construções verbo+partícula. Para o primeiro grupo, as análises expostas nos capítulos 3 e 4 mostraram que uma projeção funcional F é a responsável pela variação paramétrica dada pelo Parâmetro de Realização Fonológica de Núcleos, em conjunto com a aplicação da operação de deslocamento compulsório. Já as construções em (ii), conforme proposto acima, fazem parte de um tipo de construção de predicado complexo que se origina da mesma estrutura proposta para verbos de alternância causativo-incoativa proposta em Hale \& Keyser (2002). Qual a motivação para uma análise diferente para as estruturas (i) e (ii)? A motivação se dá pela noção de estruturas diádicas (com dois argumentos) diádicas básicas (179)a e diádicas compostas (179)b proposta por Hale \& Keyser (2002).

(179)

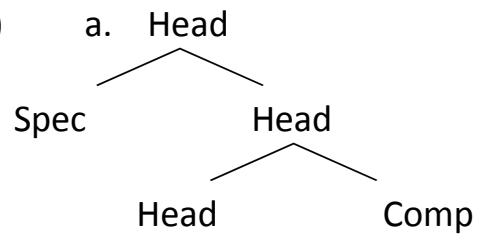

b.

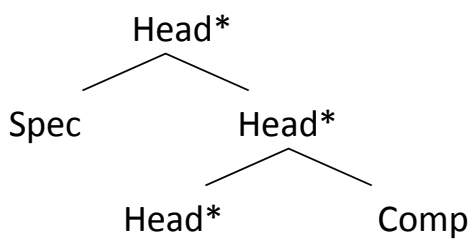

Para os autores, o núcleo de uma estrutura diádica básica (Head em (179)a) é responsável pela seleção tanto categorial quanto semântica dos argumentos que ocupam as posições de especificador e núcleo. Prototipicamente, as línguas do mundo tendem a realizar o núcleo desse tipo de projeção como uma preposição. No caso das diádicas compostas (179)b, o núcleo seleciona o complemento categorialmente e semanticamente, mas o conteúdo semântico do complemento é o que determina as características do argumento ocupando a posição do especificador. Esse núcleo (Head*) comporta-se como um núcleo funcional, atuando como um "hospedeiro sintático" de seu complemento. Devido à incapacidade de oferecer uma posição estrutural a um argumento, o elemento na posição de complemento de Head* "empresta" essa capacidade de seleção do núcleo, gerando uma estrutura diádica que, na prática, só possui um argumento (DP) de fato. 
Partindo dessas noções, será observado que a relação entre esses núcleos e a natureza dos seus argumentos, se raízes ou projeções máximas (DPs), permite derivar restrições compatíveis com as análises de restrição paramétrica propostas até aqui. Em um primeiro momento, será apontado que a projeção $\mathrm{F}$ é compatível com a noção de projeção diádica básica, e que a diferença de categorização dessa projeção depende da natureza do argumento que ocupa a posição de especificador (raiz ou DP), fato que traz consequências interessantes para a distinção entre compostos e os predicados chamados de pseudo-complexos no capítulo 2 (construções dativas, de objeto duplo e locativas). Em seguida, serão observadas as relações dos predicados complexos puros, cujas características a aproximam das ideias da estrutura diádica composta. Mais uma vez, a posição ocupada pelas raízes é crucial para determinar a configuração estrutural desses predicados, bem como derivar as diferenças entre PB e inglês adotando os parâmetros propostos nesta tese.

\subsubsection{As estruturas de núcleo preposicional: explicando a projeção $F$}

A partir das análises dos capítulos 3 e 4, é possível observar que as estruturas sintáticas de compostos do PB e do inglês, bem como das construções de alternância dativa (dativas e de objeto duplo) apresentam um núcleo preposicional, cuja realização (ou ausência) fonológica deriva as distinções apresentadas na superfície para essas línguas. Assim sendo, seria possível alterar o rótulo de F para P sem prejudicar as conclusões obtidas ao longo da tese. Mudando os rótulos, o Parâmetro de Realização Fonológica de Núcleos passa a ser definido como (180), e passa a se chamar Parâmetro de Realização Fonológica Preposicional. A Regra de Deslocamento compulsório é, portanto, definida como (181). As estruturas de 
compostos passam a ter estrturas cujos rótulos são vistos em 0 , enquanto as estruturas de alternância ficam como em (183) ${ }^{62}$ :

(180) Parâmetro de Realização Fonológica Preposicional

Uma língua permite que preposições omitam o conteúdo fonológico de seus núcleos em PF

$$
\begin{aligned}
& \{\operatorname{sim}\}=\text { inglês } \\
& \{\text { não }\}=P B
\end{aligned}
$$

(181) Regra de Deslocamento Compulsório

Um elemento ocupando a posição [Comp, P] deve se concatenar a [Spec, P], sempre que P não tiver conteúdo fonológico.

(182)

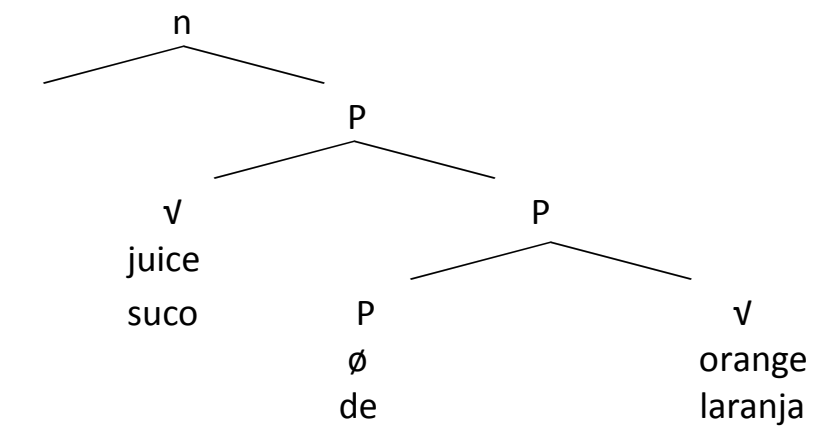

\footnotetext{
${ }^{62}$ Vale lembrar que, no caso do inglês, as estruturas ainda não teriam sofrido a aplicação da operação de
} deslocamento compulsório. 
(183)

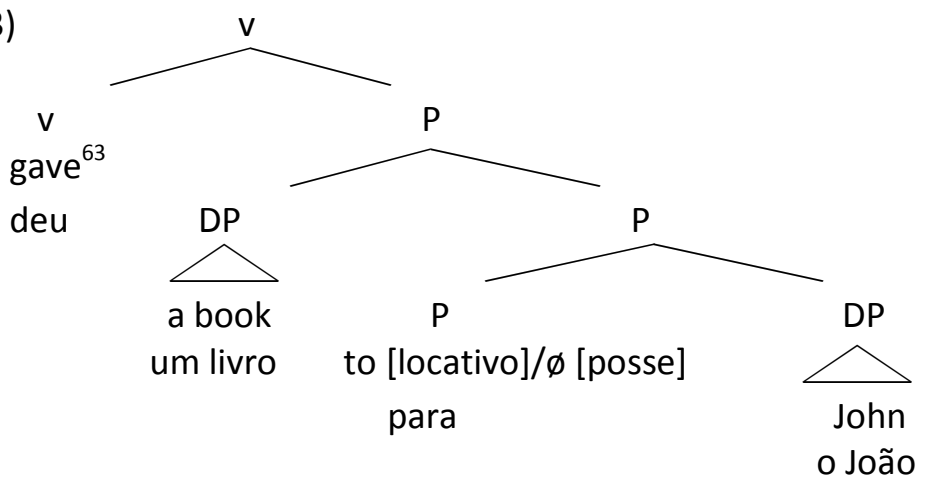

O que diferencia a estrutura em 0 da estrutura em (183) é a natureza o categorizador $n$ nos compostos, $v$ na alternância dativa - e a natureza dos elementos ocupando as posições de especificador e complemento - $V$ nos compostos, DP na alternância dativa. Seria possível dizer que compostos são definidos pela união de duas raízes não-categorizadas, enquanto estruturas de alternância dativa são caracterizadas pela presença de dois DPs no domínio de P. Porém, definições assim são vagas e não abrangem todas as possibilidades combinatórias entre os elementos participantes dessas estruturas.

Pensando primeiramente na combinação lógica entre $\mathrm{P}$ e os elementos que ocupam a posição de especificador e complemento, surgem quatro combinações possíveis:

(184)

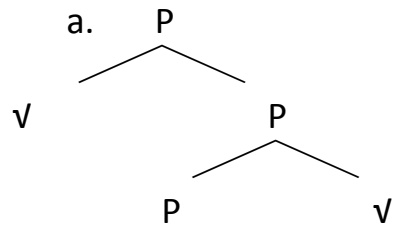

b.

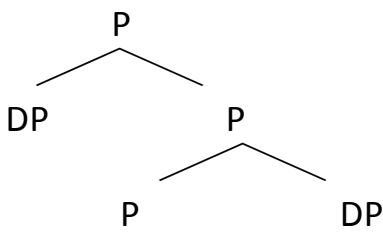

${ }^{63}$ A presença direta de deu/gave em $v$ é mera simplificação da estrutura de adjunção entre as raízes $\checkmark$ deu/Vgave e $v$ abaixo, como é possível ver em (i):

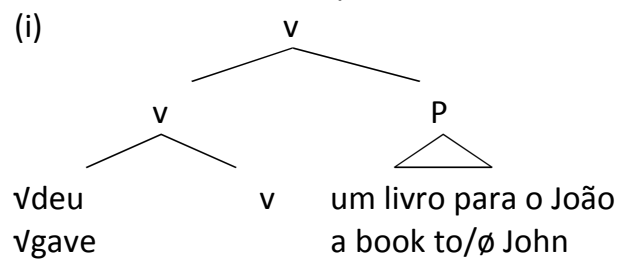



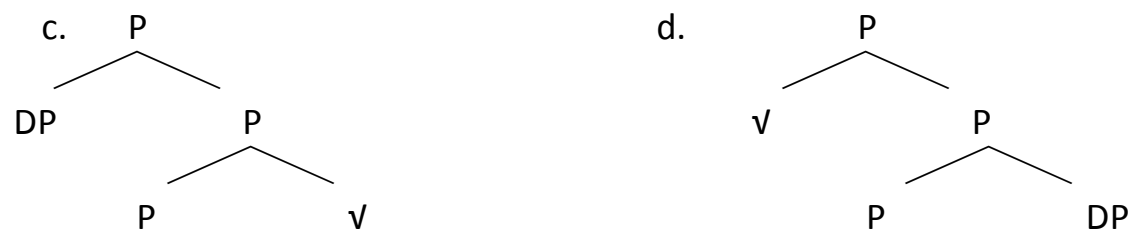

A combinação em (184)a, conforme já mencionado, é responsável pela estrutura dos nomes compostos, assim como a estrutura em (184)b é responsável pela estrutura da alternância dativa. A estrutura em (184)b é, ainda, compatível com a estrutura de construções locativas (185):

(185)

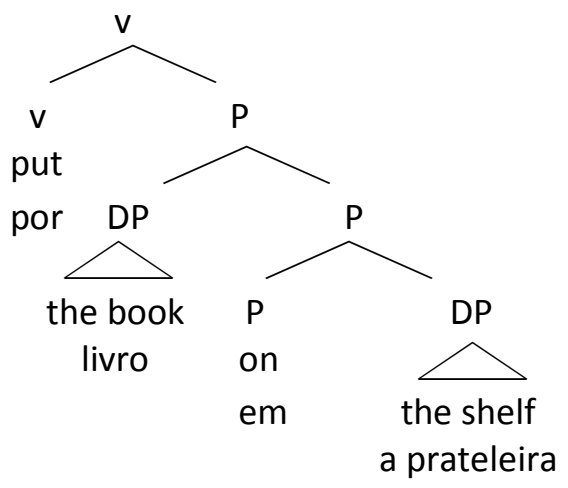

As construções locativas, por sua vez, estão diretamente relacionadas à combinação em (184)c, com uma raiz na posição de complemento e um DP na posição de especificador. Essa configuração é a mesma das estruturas que Hale \& Keyser (2002) chama de location/locatum, e da conta dos dados de alternância locativa do inglês, na qual existe, de maneira semelhante às resultativas, a verbalização dos nomes correspondentes à ação realizada (sem a presença de [modo], porém). Assim, a raiz no complemento de $\mathrm{P}$ se move 
para a posição de núcleo antes da inserção do conteúdo fonológico da mesma, movendo-se novamente para v, para formar um verbo como shelf (emprateleirar) em (186)b, abaixo ${ }^{64}$ :

(186)

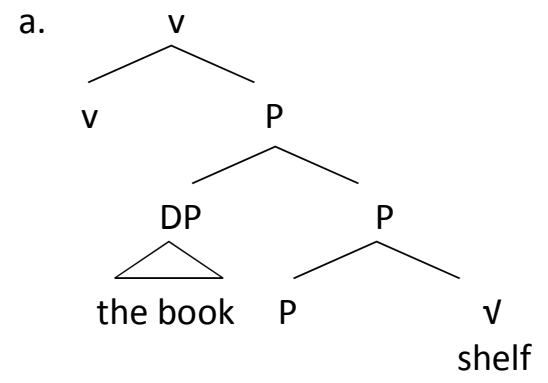

b.

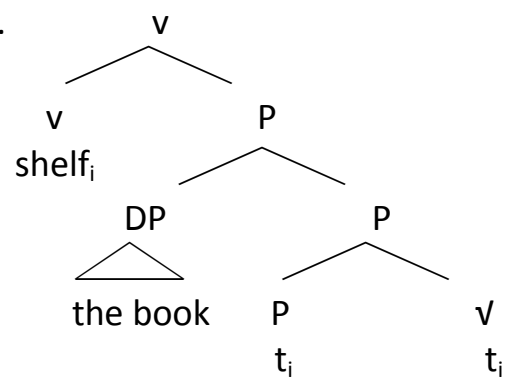

É importante lembrar que, apesar da representação em (186)b, a estrutura é montada de forma composicional, sem postular projeções vazias. Ou seja, não existe uma posição aberta para o DP the book na estrutura; ela só aparece caso o conteúdo de P+raiz licencie sua presença. Ao se juntar P+raiz, existem duas opções para a continuação da derivação: (i) preencher seu conteúdo com a fonologia de on - o que geraria uma estrutura problemática, já que a raiz shelf não poderia ser categorizada - ou (ii) permitir o movimento de shelf para P; só então, o DP the book seria adicionado à estrutura.

Dessa forma, só é possível derivar um tipo de estrutura sintática para a combinação (184)c na qual o elemento categorizador é verbal; porém, qual seria a consequência de um categorizador nominal em uma estrutura com a mesma configuração de argumentos?

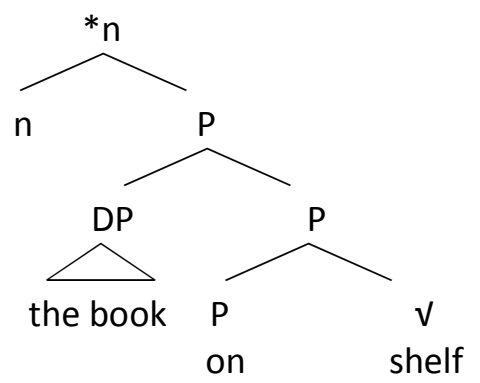

\footnotetext{
${ }^{64}$ A mesma analogia pode ser feita para verbos como emprateleirar ou engavetar, porém, com a incorporação da preposição locativa. Para uma discussão acerca deste fenômeno em PB, cf. Bassani (2009b).
} 
A estrutura em (187) é malformada pelo fato de a raiz shelf não ser categorizada preposições não são categorias lexicais produtivas como $n, a$ e $v$-além do DP the book não receber Caso - $n$ não é capaz dessa atribuição ${ }^{65}$. Por conta da questão de atribuição de Caso para os especificadores em $P$ nessa estrutura, a seguinte generalização/restrição pode ser proposta:

(188) Restrição da seleção de P

- Apenas $n$ pode selecionar P quando uma raiz ocupa (Spec, P);
- Apenas $v$ pode selecionar P quando um DP ocupa (Spec, P);
- Tanto $n$ quanto $v$ podem selecionar P quando não há especificador presente.

Assim, nomes compostos são caracterizados, no mínimo, pela presença de uma raiz na posição de especificador. No caso da posição de complemento, foi proposto, no capítulo 3, que tanto em inglês quanto em PB raízes ocupem essa posição. Porém, como evitar que o movimento da raiz para a posição de núcleo ocorra? Hale \& Keyser (2002) afirmam que as estruturas de location/locatum apresentam um núcleo preposicional estativo, que exige o movimento da raiz que ocupa a posição de complemento. Será proposto aqui que este traço esteja presente em estruturas como (189)a, em oposição ao traço [ativo] presente nos compostos (189)b.

\footnotetext{
${ }^{65}$ Poderia ser argumentado que uma estrutura de nominalização pudesse ser formada, caso shelf fosse movido para o núcleo de P. Porém, nominalizações gerundivas como (i) e (ii) aparentam possuir uma camada verbal, o que mantém a restrição proposta em (188).
}

(i) The shelving of the books.

(ii) John's shelving the books.

(iii) *The shelv[ation]/shelv[age] of the books. 
(189)

a.

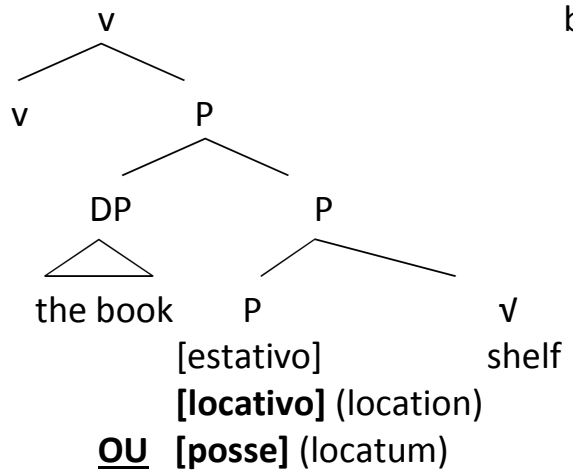

b.

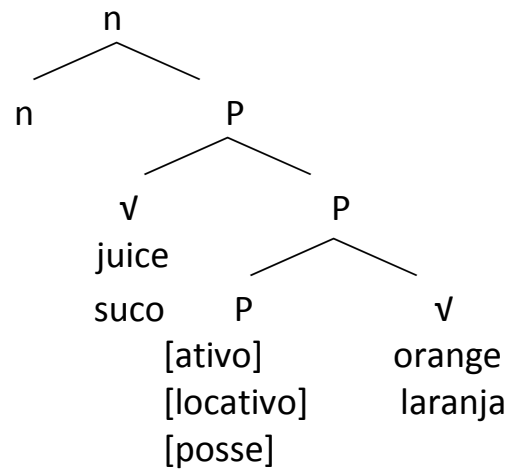

A distinção entre preposições estativas e ativas tem origem em Hale \& Keyser (2002), que, por sua vez, adotam a proposta de Hale (1985) para o warlpiri. Hale mostra que nessa língua existem uma série de elementos enclíticos que podem ser separados em dois tipos, com duas subclasses cada (cf. (190), (191), abaixo) ${ }^{66}$ :

(190) Elementos de coincidência central (estativos):

a. locativos: on, at, by, in

b. perlativos: along, over, by, past, trough, among

(HALE, 1985, p. 239-240)

(191) Elementos de coincidência terminal (ativos):

a. alativos: to, up to, onto, into

b. elativos: of, from, out of, off of

(HALE, 1985, p. 240)

É interessante notar que as preposições envolvidas na alternância dativa, bem como na interpretação semântica dos nomes compostos estão exatamente no grupo oposto ao das preposições que participam do fenômeno location/locatum. Essa separação pode ser

${ }^{66}$ Hale (1985) apresenta traduções dos elementos enclíticos do warlpiri para as preposições do inglês. 
considerada um forte argumento para a postulação dos traços [estativo] e [ativo], já que estes derivariam as diferenças estruturais relevantes nas construções aqui observadas.

Ainda é necessário discutir a configuração em (184)d, na qual uma raiz ocupa a posição de especificador e um DP é o complemento de P. Seguindo a restrição de seleção de P ((188), acima), apenas $n$ pode selecionar uma estrutura com essa configuração. Qual seria a relação entre essa estrutura e a formação de nomes compostos?

No capítulo 3, foram observados dados com $\mathrm{N}+d e+\mathrm{N}$ para o $\mathrm{PB}$, os quais não permitem ter certeza sobre qual a categoria do elemento na posição de complemento da preposição, nesses casos. Por conta desse fato, surge uma importante questão: assim como (187), acima, poderia ser dito que é necessário descartar estruturas em que uma raiz é complemento de $\mathrm{P}$ e não é movida para a posição de núcleo. Dessa maneira, apenas uma estrutura como (192), abaixo, seria compatível com as restrições estruturais propostas até aqui, em contraste a (189)b, acima, por exemplo.

Dizer que a raiz laranja em suco de laranja é categorizada separadamente não parece ser algo empiricamente conflitante com as propriedades apontadas para compostos do PB e inglês no capítulo 3 . Ainda que a categorização da raiz na posição de complemento seja realizada antes do fechamento da fase do composto como um todo, isso não aparenta ser um problema. Elementos no domínio de $\mathrm{P}$ participam da interpretação idiomática que é desencadeada pelo $n$ que seleciona P. Um argumento em favor dessa possibilidade é uma expressão idiomática formada por um DP na posição de complemento de $\mathrm{P}$, como em (193), abaixo. 
(192)

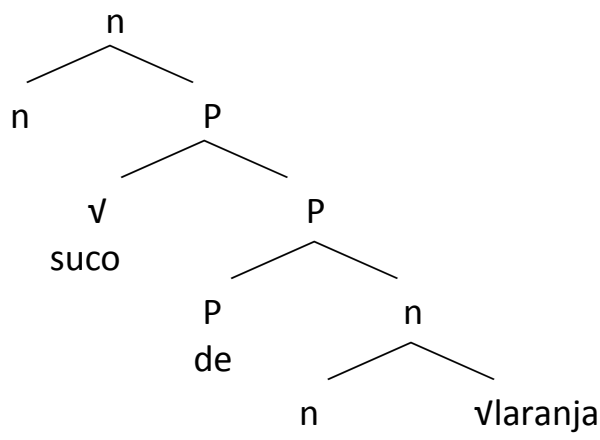

(193)

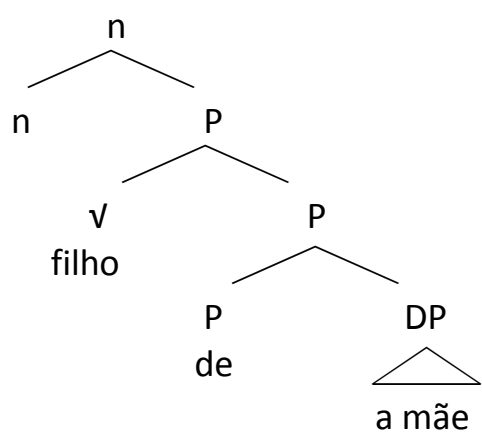

Se a análise acima estiver correta, a distinção entre PB e inglês ganha força teórica, no sentido em que, apesar de serem baseadas em configurações sintáticas em relações de ccomando idênticas, as estruturas de compostos do inglês ainda são um caso especial, derivadas pela operação de deslocamento compulsório, e a restrição do movimento dos complementos em (192) e (193) continua sendo obtida graças ao Parâmetro de Realização Fonológica Preposicional.

Com a nova formulação do Parâmetro de Realização Fonológica Preposicional, outro ponto ganha importância: existe uma clara distinção entre os fenômenos de estrutura diádica básica e os fenômenos de estrutura diádica composta, confirmando a separação proposta no capítulo 2 para os dados abordados por Sugisaki \& Snyder (2002). Em última instância, seria possível dizer que não existe relação entre compostos e predicados complexos. Afinal, apenas predicados pseudo-complexos são relevantes para o Parâmetro de Realização Fonológica Preposicional. Por outro lado, o Parâmetro de Emolduração não lida com as estruturas de 
compostos. Se as ideias propostas nesta tese estão corretas, o Parâmetro de Composição de Snyder $(1995,2001)$ tenta relacionar fenômenos que participam de parâmetros distintos.

Na próxima seção, a mesma tentativa de combinação de elementos feita para as estruturas diádicas básicas será aplicada às estruturas diádicas compostas, de modo a completar as possibilidades de formação de estruturas (relevantes aos parâmetros aqui propostos) relacionadas ao núcleo $\mathrm{P}$.

5.4.2. As estruturas de núcleo verbal: dois tipos de predicação, um tipo de v

Nesta seção, o foco recai sobre as estruturas para os predicados complexos puros, conforme a análise proposta na seção 5.4. De acordo com a análise de Barbosa (2008), a estrutura das construções resultativas é formada a partir de uma formação diádica composta (HALE; KEYSER, 2002). Dessa maneira, a mesma combinação lógica de elementos ocupando a posição de complemento e especificador feita para a formação diádica básica em (184) pode ser estendida para essas construções. Porém, apenas uma das combinações derivadas com $\mathrm{V}$ (194)c não é descartada.

(194)
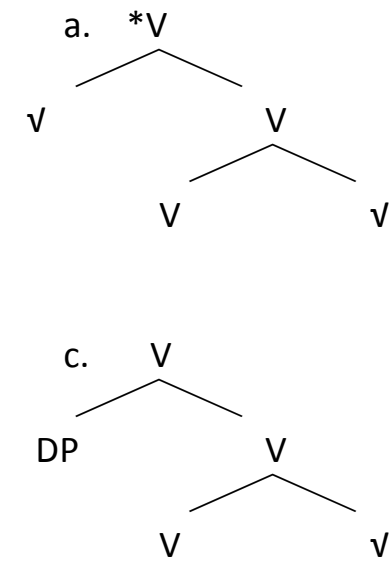

b.

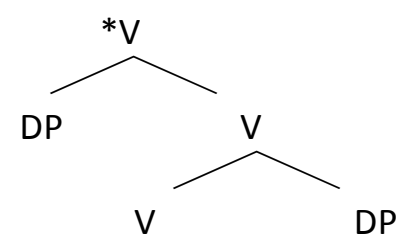

d.

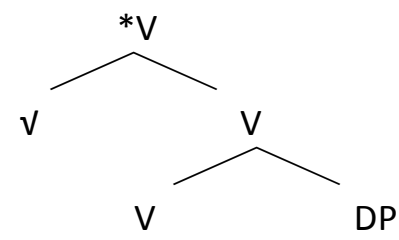


A exclusão de (194)b e (194)d se dá pelo mesmo fato: a partir do momento em que $V$ seleciona um DP, já entra em uma relação de predicação, e satura a posição disponível; ou seja, essas estruturas não existiriam, pois a combinação direta entre V e um DP gera, em todos os casos, uma estrutura monádica ${ }^{67}$. Já no caso de (194)a, a posição de (Spec, V) é destinada a um argumento, cujas propriedades semânticas devem satisfazer os requerimentos da raiz complemento de $\mathrm{V}$, o verdadeiro predicador na estrutura. Se uma raiz entra nessa posição, ela precisa ser categorizada por um $n$ para satisfazer os requerimentos de ser argumento do verbo formado a partir das restrições impostas pela raiz na posição de complemento. Como essa categorização não é possível, essa estrutura também é descartada.

Apesar dessas restrições, outros elementos além de raízes ou DPs podem ocupar a posição de complemento de V:

(195)

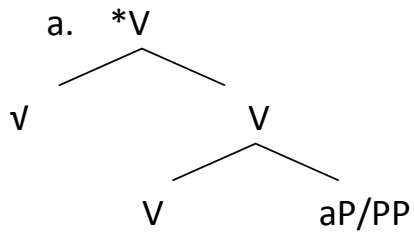

b.

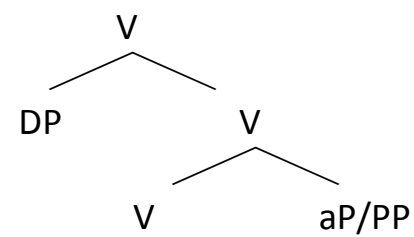

Mais uma vez, uma raiz ocupando a posição é excluída, pelos mesmos motivos de (194)a: o elemento na posição de complemento exige um argumento que satisfaça suas exigências semânticas. No caso de (195)b, é ainda necessário lembrar que essa estrutura só é válida caso haja a inserção de uma raiz em $\mathrm{V}$, formando um predicado complexo como uma construção resultativa (196) ou uma construção verbo+partícula.

\footnotetext{
${ }^{67}$ Um exemplo de estrutura monádica seria uma sentença transitiva simples, como (i), cuja estrutura relevante é apresentada abaixo, em (ii)
}

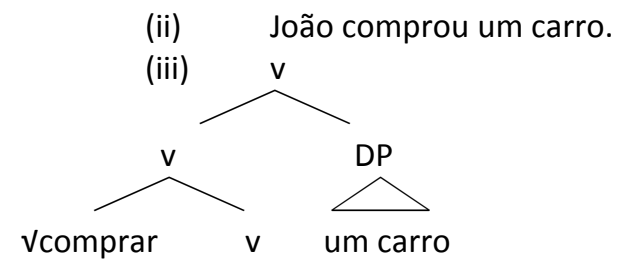




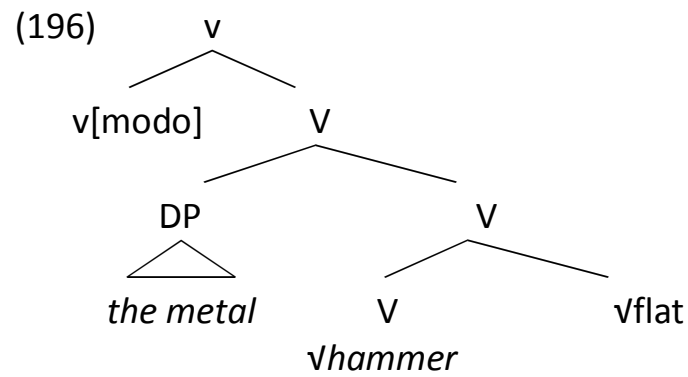

Ainda, é necessário ressaltar que a raiz não é simplesmente inserida, mas adjungida como ocorre com as operações de concatenação de todos os núcleos sintáticos - e a estrutura adequada para (196) é (197):

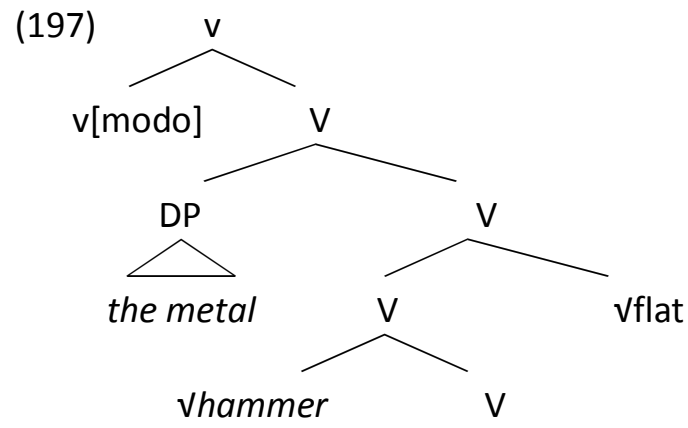

Dessa maneira, as duas estruturas possíveis na formação diádica composta são (i) a estrutura de predicados complexos puros (197) e (ii) a estrutura de alternância causativoincoativa (198).

(198)

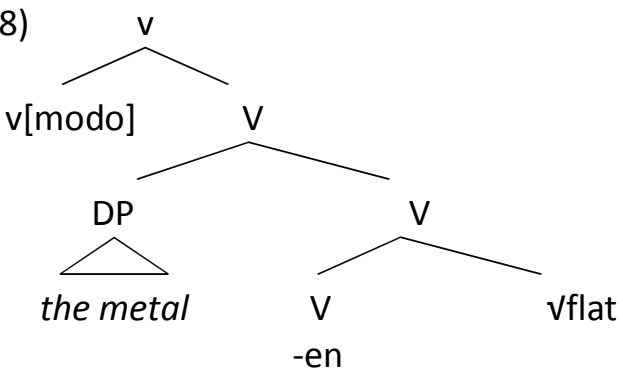


Com isso, é possível dizer que $V$ e $v$ sejam apenas instâncias de notação, mas que a natureza dos dois é, essencialmente, a mesma. A projeção de um rótulo $\mathrm{V}$ nas diádicas compostas após concatenação com DP só é consequência da incapacidade de um DP selecionar uma estrutura verbal como complemento, e pelo fato de sua entrada na estrutura sintática ser fruto da necessidade de saturação do predicado gerado a partir da posição de complemento de V. Em todos os outros contextos, v (ou V) é uma estrutura monádica, e só seleciona um argumento. A capacidade de permitir a presença de uma raiz, apesar de seu complemento ser o responsável pela exigência de selecionar um argumento na posição de complemento, é o que garante o status de predicado complexo à estrutura. Essa estrutura, por sua vez, é de natureza distinta das estruturas cujo núcleo é uma preposição, cujo conteúdo contribui para as restrições semânticas sobre o elemento que ocupará a posição de especificador - seja ele um DP ou uma raiz.

\subsection{Conclusão}

Neste capítulo, foram discutidas as propriedades dos predicados complexos puros, sua representação sintática, e as diferentes propriedades que permitem postular um parâmetro distinto para essas construções em contraste aos nomes compostos, construções locativas e construções de alternância dativa. Foi mostrado que o núcleo $F$ (ou P) relaciona tanto argumentos de estruturas verbais quanto argumentos de estruturas nominais complexas. Também foi mostrado que a combinação de traços ao longo da construção dessas estruturas determina as restrições para as relações argumentais previstas em Hale \& Keyser (2002), com o benefício de dispensar a projeção de posições vazias ao longo da derivação. 


\section{Considerações Finais}

Nesta tese, foram discutidas questões sobre variação paramétrica, um tema fundamental para o desenvolvimento do modelo teórico da Gramática Gerativa tal como ele é concebido desde a introdução do modelo de Princípios e Parâmetros (CHOMSKY, 1981, 1986). Partindo dessa concepção de linguagem humana, foi argumentado que existam dois parâmetros que lidam com a operação de composição. Essa operação na derivação computacional, de acordo com o que foi desenvolvido nesta tese, gera tanto expressões nominais (compostos) quanto expressões verbais (predicados complexos). Para dar conta dos problemas levantados por esta tese, foram propostos os seguintes parâmetros:

(199) Parâmetro de Emolduração

Uma língua permite que uma raiz denote [modo] em $v$.

$$
\begin{aligned}
& \{\text { sim }\}=\text { inglês } \\
& \{\text { não }\}=\text { PB }
\end{aligned}
$$

(200) Parâmetro de Realização Fonológica Preposicional

Uma língua permite que preposições omitam o conteúdo fonológico de seus núcleos em PF.

$\{\operatorname{sim}\}=$ inglês

$\{$ não $\}=P B$ 
A natureza desses parâmetros levanta questões sobre os modelos de variação paramétricas discutidas no capítulo 1. Apesar da escolha feita no capítulo mencionado pelo modelo de variação macroparamétrica para guiar o desenvolvimento desta tese - devido à relativa distância entre inglês e PB -, a formulação dos parâmetros acima apresenta propriedades compatíveis com a conjectura Chomsky-Borer (201), pois a escolha de marcação desses parâmetros depende exclusivamente de traços e suas relações com projeções funcionais.

(201) A Conjectura Chomsky-Borer

Todos os parâmetros de variação são atribuídos a diferenças de traços de itens particulares (e.g. núcleos funcionais) no léxico.

(BAKER, 2008b, p.3, tradução minha)

Essa aparente abrangência que os parâmetros aqui apresentados possuem sugere uma outra questão abordada pela delimitação teórica adotada: a noção de léxico. Quando o modelo da Morfologia Distribuída (HALLE; MARANTZ, 1993) é adotado para explicar as relações sintáticas nos fenômenos aqui estudados, a noção de léxico como um componente da gramática que é responsável pela formação de expressões (morfos)sintaticamente complexas faz com que a separação entre variação micro- e macroparamétrica se dilua, permitindo uma abordagem unificadora para os fenômenos em questão ao longo da tese. A Morfologia Distribuída atua como quebra de paradigma na questão da variação paramétrica, e os parâmetros em (199) e (200) podem lidar com princípios exclusivamente sintáticos, ao mesmo tempo em que explicam fenômenos tradicionalmente concebidos como questões de domínio lexical. 
Sob o ponto de vista empírico, a observação das construções abarcadas pelo Parâmetro de Composição (SNYDER, 1995), quando confrontadas com os dados do PB, mostraram que uma reformulação das intuições contidas na proposta de Snyder se fazia necessária, de modo a explicar a possibilidade de formação de determinados "predicados complexos" em PB, apesar da ausência das construções resultativas, de objeto duplo, verbopartícula e isolamento de preposição nessa língua. Enquanto a marcação positiva de (199) explica a presença de construções resultativas e construções verbo+partícula em línguas como o inglês, a marcação positiva de (200) permite que línguas desse tipo possam formar expressões nominais complexas (compostos) e expressar relações dativas com transferência de posse omitindo o conteúdo fonológico das preposições que intermediam as relações entre seus membros (raízes, no caso dos compostos, e DPs, no caso das construções de alternância dativa).

A relação entre o surgimento de nomes compostos e predicados complexos proposta por Snyder (1995, 2001), reformulada a partir dos parâmetros acima, passa a fazer muito mais sentido dentro de um modelo como o da Morfologia Distribuída, já que a formação dessas estruturas se daria em um mesmo componente computacional.

A consequência da utilização desse instrumental teórico é de extrema relevância para a questão da variação paramétrica, pois o locus da variação deixa de ser relevante. Como não há distinção entre léxico (como componente gerador de expressões sintaticamente complexas) e sintaxe, os efeitos de variação entre as línguas poderiam ser abordados, pelo menos, de duas maneiras: (i) existiriam macroparâmetros, que delimitariam propriedades mais abrangentes, marcados de maneira diferente em línguas de origens mais distantes (e.g., inglês e PB), enquanto microparâmetros delimitariam propriedades das línguas de famílias "mais próximas" (e.g., PB e PE); ou (ii) existiria um contínuo, em que variação microparamétrica se daria por um conjunto de propriedades (micro- ou macro-)paramétricas, cuja combinação resultaria na gramática de uma determinada língua. 
No caso da primeira alternativa, a obrigatoriedade de escolha entre variação micro- e macroparamétrica se dilui, já que os dois tipos de variação poderiam ocorrer simultaneamente dentro da gramática de uma língua, fato que correria à margem das definições existentes para micro- e macroparâmetros. No caso da segunda alternativa, a distinção em torno de parâmetros que conteriam propriedades mais gerais se perde, e as línguas do mundo poderiam ser agrupadas de acordo com um conjunto de comportamentos sintáticos, i.e., dependendo da presença/ausência de determinados grupos de construções, as línguas pertenceriam a um grau dentro de um contínuo, como uma escala paramétrica, ao invés de uma dependência por meio de restrições paramétricas binárias. Uma possível maneira de se imaginar esse tipo de variação dentro de um contínuo de propriedades seria como uma escala em (202):

\section{Escala de Polissíntese}

construções polissintéticas $\longrightarrow$ verbos seriais $\rightarrow$ predicados complexos/ $\rightarrow$ não-complexos nomes compostos

[+] morfologia livre

[+] marcas de caso morfológico

para manifestar concordância

abertamente

[+] ordem livre de argumentos

plenos
[+] morfologia presa

[+] marcas de Caso estrutural

[+] concordância por ordem fixa dos argumentos plenos

A escala acima seria uma alternativa para parâmetros binários, de modo que, dependendo do grau de polissíntese de cada língua, seja possível classificá-las em grupos mais 
ou menos próximos, o que poderia ser uma alternativa para uma análise binária, como, por exemplo, o Parâmetro de Polissíntese (BAKER, 1996), abaixo:

\section{O Parâmetro de Polissíntese (versão informal)}

Cada argumento de um elemento nuclear deve estar relacionado a um morfema na palavra que contém aquele núcleo (um morfema de concordância pronominal ou uma raiz incorporada)

Sim: moicano, nahautl, tiwa do sul, mayali, chukchee, (mapudungun)... Não: inglês, espanhol, chichewa, japonês, quéchua, turco, (kinande)...

(BAKER, 1996, p. 14, tradução minha)

Em suma, o que pode ser visto a partir das questões levantadas nesta tese é que os modelos atuais de variação paramétrica não são adequados para lidar com modelos como o da Morfologia Distribuída, uma vez que necessitam adequar suas propriedades que definem tanto o conceito de (micro- ou macro)parâmetro, bem como os efeitos de variação. O modelo da Morfologia Distribuída, no qual a diferença entre léxico e sintaxe é neutralizada tem consequências para as concepções de variação paramétrica tal como formuladas nas propostas de variação macro- e microparamétricas.

Assim como a concepção sintática da Morfologia Distribuída contribui para a discussão de parâmetros, a noção de emolduração de Talmy (2000) traz um ponto de vista inovador para a questão de variação paramétrica, por apontar as diferenças entre as línguas sob um ponto de vista distinto. O instrumental criado por Mateu \& Rigau (1999) para traduzir as propriedades da Semântica Cognitiva em termos sintáticos permitiu que esta tese explicitasse as noções de emolduração - que apontam mudanças cruciais na concepção de estrutura de eventos - por meio de restrições sobre uma estrutura argumental que captura as intuições de Hale \& Keyser 
(2002) para as estruturas diádicas básicas e diádicas compostas, porém, mantendo as noções de derivação estrutural dentro de um único componente computacional.

Com as questões discutidas ao longo desta tese, acredita-se ter atingido uma contribuição empírica importante, no sentido de explicitar as distinções e semelhanças dos fenômenos sintáticos analisados tanto em PB, quanto em inglês. No âmbito teórico, a contribução desta tese foi para o desenvolvimento das teorias nela citadas, de modo a oferecer reflexões acerca das questões de variação paramétrica e translinguística, dos critérios de classificação de predicados complexos e nomes compostos, bem como da explicitação sintática das intuições de emolduração presentes no modelo da Semântica Cognitiva (TALMY, 2000). Acredita-se também que essas noções possam ser tomadas como o ponto de partida para uma concepção de variação paramétrica que lide com as vantagens apresentadas pelo modelo teórico da Morfologia Distribuída (HALLE; MARANTZ, 1993), e que as variações ditas "lexicais" possam ser integradas ao componente computacional sintático, fato desejável sob o ponto de vista de economia conceptual, um dos objetivos das correntes minimalistas atuais. 


\section{Referências}

ABNEY, Steve. The Noun Phrase in Its Sentential Aspect. MIT Ph. D. Dissertation. Cambridge. 1987.

AMARAL, Luana Lopes. Os verbos de modo de movimento no português brasileiro. Monografia (Bacharelado em Letras: habilitação em Linguística) - Faculdade de Letras, Universidade Federal de Minas Gerais, Minas Gerais, 2010. Disponível em: http://www.letras.ufmg.br/nucleos/nupes/dados/arquivos/Monografia\%20Luana\%20Lo pes\%20Amaral\%202010-02.pdf. Acesso em: 06-11-2012.

ARMELIN, Paula Roberta Gabbai. Sentenças bitransitivas do português do Brasil revisitas à luz da teoria de núcleos funcionais aplicativos. Dissertação (Mestrado em Semiótica e Linguística Geral) - Faculdade de Filosofia, Letras e Ciências Humanas, Universidade de São Paulo, São Paulo, 2011. Disponível em: http://www.teses.usp.br/teses/disponiveis/8/8139/tde-04052011-142215/. Acesso em: 06-11-2012.

ARMELIN, Paula Roberta Gabbai; BARBOSA, Julio William Curvelo. Variações paramétricas em línguas românicas e germânicas: uma análise para as construções dativas. Trabalho apresentado no II Congresso Internacional de Linguística Histórica. USP: São Paulo. Fevereiro, 2012.

BAKER, Mark. The Syntax of Agreement and Concord. Cambridge Studies in Linguistics, n. 115. Cambridge University Press, 292p. 2008a. 
. The Macroparameter in a Microparametric World. In: BIBERAUER, T. (Ed.). The Limits

of Syntactic Variation, John Benjamins, Amsterdam, p. 351-374. 2008b.

. The polysynthesis parameter. Oxford: Oxford University Press, 1996.

BASSANI, Indaiá de Santana. Formação e interpretação dos verbos denominais do português do Brasil. 2009. Dissertação (Mestrado em Semiótica e Lingüística Geral) - Faculdade de Filosofia, Letras e Ciências Humanas, Universidade de São Paulo, São Paulo, 2009.

Disponível em: http://www.teses.usp.br/teses/disponiveis/8/8139/tde-23112009144713/. Acesso em: 06-11-2012.

- Verbos denominais e a relação sincrônica com os substantivos formadores: descrições. ReVEL, vol. 7, n. 12, 2009. Dsiponível em: http://www.revel.inf.br/files/artigos/revel 12 verbos denominais.pdf. Acesso em: 0611-2012.

BARBOSA, Julio. A estrutura sintática das chamadas 'construções resultativas em $P B^{\prime}$. Dissertação de Mestrado. Universidade de São Paulo. 2008.

BARBOSA, Julio; SIMIONI, Leonor. Aquisição do Parâmetro de Composicionalidade: uma análise translinguística. Trabalho apresentado no Encontro do GT de Teoria da Gramática da ANPOLL. Brasília, Universidade de Brasília. 2009.

BARSS, A.; LASNIK, H. A note on Anaphora and Double Objects. Linguistic Inquiry 17, p. 347354. 1986.

BASILIO, Margarida. Teoria Lexical. São Paulo: Ática, 1987.

BAUER, L. Compounds and minor word-formation types. In: AARTS, Bas; MCMAHON, April (Eds.). The Handbook of English Linguistics, Malden, MA: Blackwell, p. 483-506, 2006.

BRESNAN, Joan; NIKITINA, Tatiana. The Gradience of the Dative Alternation. In: Reality Exploration and Discovery: Pattern Interaction in Language and Life, UYECHI, Linda; WEE, Lian Hee (Eds.). p. 161-184. Stanford: CSLI Publications. 2008. Disponível em: http://www.stanford.edu/ bresnan/bresnan-nikitina.proof.pdf. Acesso em: 06-11-2012. 
CHOMSKY, Noam. The minimalist program. Cambridge: The MIT Press, 1995.

. Language and Problems of Knowledge: The Managua Lectures. Current Studies in Linguistics. MIT Press. 215p. 1987.

. Knowledge of language: Its nature, origins and use. New York: Praeger, 1986.

. Lectures on Government and Binding. Foris: Dordrecht, 1981.

. The Logical Structure of Linguistic Theory. Chicago: University of Chicago Press. (1955/1975).

DAVIES, Mark; PRETO-BAY, Ana Maria Rapaso. A Frequency Dictionary of Portuguese. Bookseller: The Book Depository. Guernsey, GY, United Kingdom. Routledge, Jan 28. 342p. 2008.

DI SCIULLO, Anna Maria. Decomposing Compounds. In: Skase Journal of theoretical linguistics. Vol. 2, n. 3, p. 14-33, 2005.

GOMES, Tânia Vieira. Os nomes compostos em português. Dissertação (Mestrado em Letras) Pontifícia Universidade Católica do Rio de Janeiro, Rio de Janeiro, 74 f. 2005. Disponível em:

http://www.maxwell.lambda.ele.pucrio.br/Busca etds.php?strSecao=resultado\&nrSeq=7461@1. Acesso em: 06-11-2012.

EMBICK, David. On the structure of resultative participles in English. Linguistic Inquiry 35.3, p. 355-392, 2004.

EMBICK, David; NOYER, Rolf. Distributed morphology and the syntax/morphology interface. In: RAMCHAND, G.; REISS, C. (Eds.). The Oxford handbook of linguistic interfaces. Oxford: University Press. p. 1-27. 2004.

GONÇALVES, Anabela. Predicados complexos verbais em contextos de infinitivo não preposicionado do português europeu. Tese de Doutorado, Universidade de Lisboa, 1999.

HAEGEMAN, Liliane. Introduction to Government and Binding Theory. Second Edition. Cambridge, Massachusetts: Blackwell. 1994. 
HALE, Ken; KEYSER, Samuel Jay. Prolegomenon to a theory of argument structure. Linguistic inquiry monographs. 39. Massachusetts: MIT Press, 2002.

. The basic elements of argument structure. MIT Working papers in linguistics 32:

Papers from the Upenn/ MIT Roundtable on Argument Structure, HARLEY, Heidi. (Ed.). p.

73-118, Cambridge (Mass.): MIT Press. 1998.

. The limits of argument structure. In: MENDIKOETXEA, A.; URIBEETXEBARRIA, M.

(Eds.). Theoretical Issues at the Morphology-Syntax Interface. p. 203-230. Bilbao:

Servicio de Publicaciones de la UPV. 1997.

. On the argument structure and the lexical expression of syntactic relations. In: The

View from Building 20: Essays in Linguistics in Honor of Sylvain Bromberger, HALE, Ken

\& KEYSER, Samuel Jay (Eds.). p. 53-109. Cambridge (Mass.): MIT Press. 1993.

HALLE, Morris; MARANTZ, Alec. Distributed morphology and the pieces of inflection. In: HALE,

Ken; KEYSER, Samuel Jay. (eds.). The view from building 20: Essays in Linguistics in Honor of Sylvian Bromberger. Cambridge, MA: MIT Press. p. 111-176, 1993.

HARLEY, Heidi. The bipartite structure of verbs cross-linguistically. Write-up of a talk given at the 2007 ABRALIN Congress in Belo Horizonte, Brazil, March 2007.

. Possession and the double object construction. Yearbook of Linguistic Variation 2, p.

29-68. 2002.

HOEKSTRA, T. Small clause results. Língua 74, p. 101-139, 1988.

JAKOBSON, Roman. Selected Writings. vol. II, The Hague: Mouton. p. 260-266. 1971.

KEHDI, V. Formação de palavras em português. São Paulo: Ática, 1992.

KOOPMAN, H. On Deriving Deep and Surface Order. In: JONES, C.; SELLS, P. (Eds.). Papers from

the Fourteenth Annual Meeting of NELS, GLSA. University of Massachusetts, Amherst. 1985.

LARSON, R. K. On the Double Object Construction. Linguistic Inquiry 19, p. 335-391, 1988. 
. The Antisymmetry of Syntax. Linguistic Inquiry Monograph 25. Massachusetts. The

MIT Press. 1994.

. Some Notes on Comparative Syntax, with Special Reference to English and French.

In: CINQUE, G.; KAYNE, R. (Eds.). Handbook of Comparative Syntax, Oxford University Press, New York, p. 3-69, 2005.

LEVIN, B.; RAPPAPORT HOVAV, M. Unaccusativity: at the syntax-lexical semantics interface.

Linguistic Inquiry Monograph 26. Cambridge, MA: MIT Press, 1995.

MARANTZ, Alec. No escape from syntax: don't try morphological analysis in the privacy of your own lexicon, In: University of Pennsylvania Working Papers 4.2. 1997.

. Words. West Coast Conference on Formal Linguistics. University of Southern

California, Los $2001 . \quad$ Disponível em: http://web.mit.edu/marantz/Public/EALING/WordsWCCFL.pdf. Acesso em: 01-08-2010.

MARCELINO, M. Construções resultativas em português e inglês: Uma nova análise. Dissertação de Mestrado - Pontifícia Universidade Católica de São Paulo, 2000.

MATEU, J. Small clause results revisited. ZAS Papers in Linguistics, vol. 26. Proceedings of the Workshop on the Syntax of predication, 2001.

MATEU, J.; RIGAU, G. Universals of Lexico-syntactic Typology and Parametric Variation. Paper presented at the 1999 GLOW on Universals, ZAS, Berlin. 1999.

MORO, Andrea. Topics in small clauses with predicative nominal. In: Small Clauses, CARDINALETTI, A.; GUASTI, M. T. (Eds.). Academic Press, New York, p. 109 - 132, 1995.

NEELEMAN, A.; VAN DE KOOT, H. Bare resultatives. Journal of Comparative Germanic Linguistics, 6 (1), p. 1-52, 2002.

NEVES, Maria Helena Moura. Gramática de usos do português. São Paulo: Editora da UNESP, 2000.

OLSEN, Susan. Semantics of Compounds. In: MAIENBORN, C.; HEUSINGER, K. V.; PORTNER, P. (Eds.). Semantics: An International Handbook of Natural Language Meaning = 
Handbücher zur Sprach- und Kommunikationswissenschaft, Berlin: Mouton de Gruyter. 2008.

PESETSKY, David. Zero syntax. Cambridge, MA: MIT Press. 1995.

PINKER, S. Learnability and Cognition: The Acquisition of Argument Structure. Cambridge: The MIT Press. 1989.

PLAG, I. Word-formation in English. Cambridge Textbooks in Linguistics. Cambridge: Cambridge University Press. 2003.

PYLKKÄNEN, L. Introducing Arguments. Ph.D. Thesis. MIT. Cambridge, MA. 2002.

RAMCHAND, Gillian; SVENONIUS, Peter. The Lexical Syntax and Lexical Semantics of the VerbParticle Construction. WCCFL 21. p. 101-114, 2002.

RICHARD, Kayne S. Principles of Particle Constructions. In: GUERÓN, J.; OBENAUER, H. G.; POLLOK, J. Y. (Eds.). Grammatical Representation, p. 101-140. Dordrecht: Foris. 1985.

RICHARDS, Norvin. An Idiomatic Argument for Lexical Decomposition. Linguistic Inquiry 32, p. 183-192. MIT Press. 2001.

RIZZI, Luigi. Issues in Italian syntax. Foris, Dordrecht. 1982.

ROBERTS, Ian. Agreement Parameters and the Development of English Modal Auxiliaries. Natural Language and Linguistic Theory 3, p. 21-58. 1985.

ROTHSTEIN, Susan. Structuring events: A study in the semantics of lexical aspect. Oxford: Blackwell's. 2004.

SCHEIN, Barry. Predication. In: CARDINALETTI, A.; GUASTI, T. (Eds.). Small clauses, Syntax and Semantics 28, p. 49-76. (1982/1995).

SCHER, Ana Paula. As construções com dois objetos no inglês e no português do Brasil: um estudo sintático comparativo. M.A. Thesis. Universidade Estadual de Campinas. 1996.

SNYDER, William B. Language Acquisition and Language Variation: The Role of Morphology. Ph.D. dissertation, MIT. Cambridge, MA: MIT Press, 1995. 
. On the nature of syntactic variation: Evidence from complex predicates and complex word-formation. Language 77. p. 324-342, 2001.

SPENCER, Andrew. Morphological theory: an introduction to word structure in generative grammar. N. 2, In: Blackwell textbooks in linguistics. Oxford: Blackwell, 1991.

STOWELL, T. Origins of phrase structure. Ph.D. Dissertation - MIT, 1981.

SUGISAKI, Koji; SNYDER, William B. Preposition stranding and the Compounding Parameter: A developmental perspective. In: SKARABELA, B.; FISH, S.; DO, A. H. J. (Eds.) Proceedings of the 26th Boston University Conference on Language Development, p. 677-688. Somerville, MA: Cascadilla Press. 2002.

TALMY, L. Toward a cognitive semantics. 2 volumes. Cambridge, MA: Massachusetts Institute of Technology, 2000.

TEIXEIRA, Lílian Figueiró. A semântica dos compostos nominais - um estudo de corpus paralelo inglês/português. 2009. Dissertação (Mestrado em Linguística Aplicada) - Universidade do Vale do Rio dos Sinos, São Leopoldo, 2009. Disponível em: http://bdtd.unisinos.br/tde arquivos/7/TDE-2009-07-23T110437Z-

799/Publico/TeixeiraLilianFigueiroLinguistica.pdf. Acesso em: 06-11-2012.

TORRES-MORAIS, Maria Aparecida. Os Dativos. Tese de Livre Docência, São Paulo: USP. 2007.

TRAVIS, L. Parameters and Effects of Word Order Variation. Doctoral dissertation, MIT, Cambridge, Massachusetts. 1985.

VILLAVICENCIO, Aline, FINATTO, Maria José Bocorny, POSSAMAI, Viviane. Padrões da Preposição "DE" entre Sintagmas Nominais em Linguagem Cotidiana e Linguagens Técnico-Científicas. In: Proceedings of the $\mathbf{V}$ Encontro de Corpora, São Carlos, 2005. 